\title{
PHOSPHORYLATION OF GLYCOLYTIC ENZYMES IN HIBERNATION
}

\author{
Allan Letourneau \\ BA (St. Thomas), BSc (U.N.B), BSc (Hons) (MtA)
}

A Thesis Submitted to the Faculty of Graduate Studies and Research in partial fulfilment of the requirements for the degree of

\author{
Master of Biology \\ Department of Biology \\ Ottawa-Carleton Institute of Biochemistry \\ Carleton University \\ Ottawa, Ontario, Canada \\ C copyright 2010 \\ Allan Letourneau
}

The undersigned herby recommend to the Faculty of Graduate Studies and Research acceptance of this thesis 


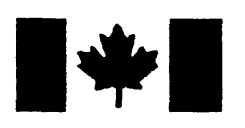

\author{
Library and Archives \\ Canada \\ Published Heritage \\ Branch \\ 395 Wellington Street \\ Ottawa ON K1A ON4 \\ Canada
}

Bibliothèque et

Archives Canada

Direction du

Patrimoine de l'édition

395 , rue Wellington

Ottawa ON K1A ON4

Canada
Your file Votre référence

ISBN: 978-0-494-71588-8

Our file Notre référence

ISBN: 978-0-494-71588-8
NOTICE:

The author has granted a nonexclusive license allowing Library and Archives Canada to reproduce, publish, archive, preserve, conserve, communicate to the public by telecommunication or on the Internet, loan, distribute and sell theses worldwide, for commercial or noncommercial purposes, in microform, paper, electronic and/or any other formats.

The author retains copyright ownership and moral rights in this thesis. Neither the thesis nor substantial extracts from it may be printed or otherwise reproduced without the author's permission.
AVIS:

L'auteur a accordé une licence non exclusive permettant à la Bibliothèque et Archives Canada de reproduire, publier, archiver, sauvegarder, conserver, transmettre au public par télécommunication ou par l'Internet, prêter, distribuer et vendre des thèses. partout dans le monde, à des fins commerciales ou autres, sur support microforme, papier, électronique et/ou autres formats.

L'auteur conserve la propriété du droit d'auteur et des droits moraux qui protège cette thèse. $\mathrm{Ni}$ la thèse ni des extraits substantiels de celle-ci ne doivent être imprimés ou autrement reproduits sans son autorisation.
In compliance with the Canadian Privacy Act some supporting forms may have been removed from this thesis.

While these forms may be included in the document page count, their removal does not represent any loss of content from the thesis.
Conformément à la loi canadienne sur la protection de la vie privée, quelques formulaires secondaires ont été enlevés de cette thèse.

Bien que ces formulaires aient inclus dans la pagination, il n'y aura aucun contenu manquant.

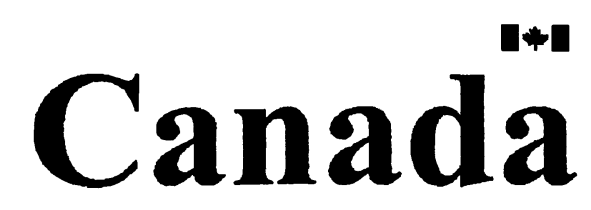




\begin{abstract}
Glycerol-3-phosphate dehydrogenase (G3PDH) and lactate dehydrogenase (LDH) were examined for differential phosphorylation, accompanying kinetics and stability in Spermophilus richardsonii liver and skeletal muscle. Hibernator G3PDH had a higher phosphate content and differential kinetics in both tissues which could be manipulated by kinase and phosphatase incubations in the G3P utilizing direction. Arrhenius plots and activation energies $\left(E_{a}\right)$ showed that the hibernator form had a lower $E_{a}$ in both tissues, especially in the liver. Euthermic LDH had a higher phosphate content and differential kinetics which could be manipulated by kinase and phosphatase incubations in both directions. Euthermic forms had lower $E_{a}$ values in both tissues. G3PDH and LDH had differential urea $\mathrm{I}_{50}$ values with the hibernator more susceptible to urea denaturation in both tissues. Urea $\mathrm{I}_{50}$ values could be manipulated in $\mathrm{LDH}$ by kinase and phosphatase incubations in the liver but not in muscle.
\end{abstract}




\section{Acknowledgements}

I first would like to thank Dr. Peter Cashion of UNB whose dedication to overcoming impossible odds in society and for having the ability to express those concerns reflects clearly on his students. Literally, if it was not for him telling me the 'tale' of biochemistry, my life would be completely different. Also, thanks for letting me know that lab work at MtA might be good for me.

Second, I would like to thank Jack Stewart of MtA (retired) who showed me the meaning of hard work and sticking to your principles, especially when you know they are right. Without guidance from him, I would have not found 'my way' in this field.

Third, I would like to thank Dr. Kenneth B. Storey and Jan Storey for accepting me in their lab and providing me with the ability to discover a bright future for myself. But, more importantly, thanks for showing me the meaning of family.

Fourth, I would like to thank the members of the Storey lab who have made things interesting during my time here, especially Craig Brooks for learning stalemate could be a good thing, Kyle Bigger for leadership when it is needed, Ben Lant for keeping us fit with outside sports, Mike Wu and Alex Holden for cheering me up with their relationship, Shannon Tessier for knowing enough medicine and Neil Dawson for worse case scenarios before they happen and for bringing the philosophy of sport to biochemistry.

Finally, I am thanking MY daughter Alina Letourneau for being part of my life and for putting up with my nonsense until it makes sense. 


\section{Table of Contents}

$\begin{array}{ll}\text { Page } & \text { Pan }\end{array}$

Title Page

i

Acceptance Sheet $\quad$ ii

Abstract $\quad$ iii

Acknowledgements

Table of Contents $\quad \mathrm{v}$

List of Abbreviations $\quad$ vi

List of Figures viii

List of Tables $\quad$ xi

$\begin{array}{lll}\text { Chapter } 1 \quad \text { General Introduction } & 1\end{array}$

$\begin{array}{lll}\text { Chapter } 2 \quad \text { Materials and Methods } & 6\end{array}$

Chapter $3 \quad$ Liver and Muscle G3PDH 16

$\begin{array}{lll}\text { Chapter } 4 \quad \text { Liver and Muscle LDH } & 60\end{array}$

$\begin{array}{lll}\text { Chapter } 5 & \text { General Discussion } & 104\end{array}$

References 
List of Abbreviations:

ATP

AMP

cAMP

cGMP

DHAP

$\mathrm{E}_{\mathrm{a}}$

EDTA

EGTA

ETC

G3PDH

G3P

$\mathrm{GHCl}$

GPD1

LA

$\mathrm{LDH}$

MRE

MRD

$\mathrm{NADH}$

$\mathrm{NAD}^{+}$

$\mathrm{Na}_{3} \mathrm{VO}_{4}$

PKA

PMSF

PTM

PVDF
Adenosine triphosphate

Adenosine monophosphate

Cyclic 3'5' adenosine monophosphate

Cyclic guanosine 3'5'-monophosphate

Dihydroxyacetone phosphate

Activation Energy

Ethylenediamine-tetraacetic acid

Ethylene glycol-bis(2-aminoethylether)-N,N,N',N'-tetraacetic acid

Electron transport chain

Glycerol-3-phosphate dehydrogenase

Glycerol-3-phosphate

Guanadine hydrochloride

Glycerol-3-phosphate dehydrogenase subunit 1

Lactic acid

Lactate dehydrogenase

Metabolic rate excitation

Metabolic rate depression

$\beta$-Nicotinamide adenine dinucleotide, reduced form

$\beta$-Nicotinamide adenine dinucleotide, oxidized form

Sodium orthovanadate

Protein kinase A

Phenylmethylsulfonyl fluoride

Posttranslational modification

Polyvinylidene difluoride membrane 
RGS

RPP

SDS-PAGE

$\mathrm{Tb}$

TBST

TEMED
Richardson Ground Squirrel

Reversible protein phosphorylation

Sodium dodecyl sulfate polyacylamide gel electrophoresis

Body temperature

Tris-buffered saline containing the detergent Triton-X

$\mathrm{N}, \mathrm{N}, \mathrm{N}^{\prime}, \mathrm{N}^{\prime}$-tetramethyl-ethane-1,2-diamine 


\section{List of Figures}

Figure

Page

\begin{tabular}{|c|c|c|}
\hline 3.1 & Glycerol-3-phosphate shuttle system & 18 \\
\hline 3.2 & $\begin{array}{l}\text { Effect of } \mathrm{pH} \text { on G3PDH activity from A) liver and B) muscle of } \\
\text { euthermic and hibernating } S \text {. richardsonii. G3P direction }\end{array}$ & 30 \\
\hline 3.3 & $\begin{array}{l}\text { Effect of } \mathrm{pH} \text { on G3PDH activity from A) liver and B) muscle of } \\
\text { euthermic and hibernating } S \text {. richardsonii. DHAP direction. }\end{array}$ & 31 \\
\hline 3.4 & $\begin{array}{l}\text { G3PDH elution profiles off a hydroxyapatite column. Euthermic and } \\
\text { hibernating liver. }\end{array}$ & 32 \\
\hline 3.5 & $\begin{array}{l}\text { G3PDH elution profiles off a hydroxyapatite column. Euthermic and } \\
\text { hibernating muscle }\end{array}$ & 33 \\
\hline 3.6 & $\begin{array}{l}\text { Western blotting assessing G3PDH protein levels in (A) liver and (B) } \\
\text { muscle of of euthermic versus hibernating } S \text {. richardsonii. }\end{array}$ & 34 \\
\hline 3.7 & $\begin{array}{l}\text { Relative amount of phosphorylated G3PDH as detected by ProQ } \\
\text { Diamond staining in samples of partial purified enzyme from (A) liver } \\
\text { and (B) muscle and euthermic and hibernating } S \text {. richardsonii. }\end{array}$ & 35 \\
\hline 3.8 & $\begin{array}{l}\text { Kinetic parameters of liver G3PDH from euthermic and hibernating } S \text {. } \\
\text { richardsonii }\end{array}$ & 36 \\
\hline 3.9 & $\begin{array}{l}\text { Kinetic parameters of skeletal muscle G3PDH from euthermic and } \\
\text { hibernating } S \text {. richardsonii }\end{array}$ & 37 \\
\hline 3.10 & $\begin{array}{l}\text { Effect of incubations under conditions that stimulate the action of } \\
\text { protein kinases or protein phosphatases on the } \mathrm{K}_{\mathrm{m}} \mathrm{G} 3 \mathrm{P} \text { of G3PDH from } \\
\text { crude extracts of liver for euthermic versus hibernating } S \text {. richardsonii }\end{array}$ & 38 \\
\hline 3.11 & $\begin{array}{l}\text { Effect of incubations under conditions that stimulate the action of } \\
\text { protein kinases or protein phosphatases on the } \mathrm{K}_{\mathrm{m}} \mathrm{G} 3 \mathrm{P} \text { of G3PDH from } \\
\text { crude extracts of muscle for euthermic versus hibernating } S \text {. richardsonii }\end{array}$ & 39 \\
\hline 3.12 & $\begin{array}{l}\text { Arrhenius plots showing the effect of temperature on liver G3PDH from } \\
\text { euthermic and hibernating } S \text {. richardsonii }\end{array}$ & 40 \\
\hline 3.13 & $\begin{array}{l}\text { Arrhenius plots showing the effect of temperature on muscle G3PDH } \\
\text { from euthermic and hibernating } S \text {. richardsonii }\end{array}$ & 41 \\
\hline 3.14 & $\begin{array}{l}\left.\text { Calculated activation energies ( } \mathrm{E}_{\mathrm{a}}\right) \text { for the G3P utilizing direction of } \mathrm{A} \text { ) } \\
\text { liver and } \mathrm{B} \text { ) muscle G3PDH from euthermic and hibernating } S . \\
\text { richardsonii assayed in phosphate buffer or imidazole }\end{array}$ & 42 \\
\hline 3.15 & $\begin{array}{l}\mathrm{K}_{\mathrm{m}} \text { G3P vs temperature curves for A) liver and B) muscle G3PDH from } \\
\text { euthermic and hibernating } S \text {. richardsonii }\end{array}$ & 43 \\
\hline 3.16 & $\begin{array}{l}\text { Km G3P vs temperature curves for A) liver and B) muscle G3PDH from } \\
\text { euthermic and hibernating } S \text {. richardsonii }\end{array}$ & 44 \\
\hline 3.17 & $\begin{array}{l}\text { Effect of high } \mathrm{KCl} \text { concentrations on } \mathrm{K}_{\mathrm{m}} \mathrm{G} 3 \mathrm{P} \text { of } \mathrm{A} \text { ) liver and } \mathrm{B} \text { ) muscle } \\
\text { G3PDH from euthermic and hibernating } S \text {. richardsonii }\end{array}$ & 45 \\
\hline 3.18 & $\begin{array}{l}\text { Effects of guanidine hydrochloride on } \mathrm{K}_{\mathrm{m}} \mathrm{G} 3 \mathrm{P} \text { of A) liver and B) muscle } \\
\text { G3PDH from euthermic and hibernating } S \text {. richardsonii }\end{array}$ & 46 \\
\hline 3.19 & $\begin{array}{l}\text { Urea effects on } \mathrm{K}_{\mathrm{m}} \mathrm{G} 3 \mathrm{P} \text { of } \mathrm{A} \text { ) liver and B) muscle G3PDH from } \\
\text { euthermic and hibernating } S \text {. richardsonii. }\end{array}$ & 47 \\
\hline
\end{tabular}




\begin{tabular}{|c|c|c|}
\hline 3.20 & $\begin{array}{l}\text { Effect of urea on A) liver and B) muscle G3PDH maximal activity from } \\
\text { euthermic and hibernating S. richardsonii }\end{array}$ & 48 \\
\hline 3.21 & $\begin{array}{l}\mathrm{I}_{50} \text { values for urea inhibition of A) liver and B) muscle G3PDH from } \\
\text { euthermic and hibernating } S \text {. richardsonii }\end{array}$ & 49 \\
\hline 4.1 & $\begin{array}{l}\text { Overall reaction for the reversible NAD+ dependant lactate } \\
\text { dehydrogenase (E.C. 1.1.1.27). }\end{array}$ & 62 \\
\hline 4.2 & $\begin{array}{l}\text { Effect of } \mathrm{pH} \text { on } \mathrm{LDH} \text { activity from } \mathrm{A} \text { ) liver and B) muscle of euthermic } \\
\text { and hibernating Spermophilus richardsonii. LA direction }\end{array}$ & 72 \\
\hline 4.3 & $\begin{array}{l}\text { Effect of } \mathrm{pH} \text { on } \mathrm{LDH} \text { activity from A) liver and B) muscle of euthermic } \\
\text { and hibernating Spermophilus richardsonii. Pyruvate direction }\end{array}$ & 73 \\
\hline 4.4 & $\begin{array}{l}\text { LDH elution profiles off a hydroxyapatite column. Euthermic and } \\
\text { hibernating liver }\end{array}$ & 74 \\
\hline 4.5 & $\begin{array}{l}\text { LDH elution profiles off a hydroxyapatite column. Euthermic and } \\
\text { hibernating muscle }\end{array}$ & 75 \\
\hline 4.6 & $\begin{array}{l}\text { Western blotting assessing LDH protein levels in (A) liver and (B) } \\
\text { muscle of euthermic versus hibernating S. richardsonii }\end{array}$ & 76 \\
\hline 4.7 & $\begin{array}{l}\text { Relative amount of phosphorylated LDH as detected by ProQ Diamond } \\
\text { staining in samples of partial purified enzyme from (A) liver and (B) } \\
\text { muscle of euthermic and hibernating S. richardsonii }\end{array}$ & 77 \\
\hline 4.8 & $\begin{array}{l}\text { Kinetic parameters of liver LDH from euthermic and hibernating } S \text {. } \\
\text { richardsonii }\end{array}$ & 78 \\
\hline 4.9 & $\begin{array}{l}\text { Kinetic parameters of skeletal muscle LDH from euthermic and } \\
\text { hibernating } S \text {. richardsonii }\end{array}$ & 79 \\
\hline 4.10 & $\begin{array}{l}\text { Effect of incubations under conditions that stimulate the action of } \\
\text { protein kinases or protein phosphatases on the } \mathrm{K}_{\mathrm{m}} \text { LA of LDH from } \\
\text { crude extracts of liver for euthermic versus hibernating S. richardsonii. }\end{array}$ & 80 \\
\hline 4.11 & $\begin{array}{l}\text { Effect of incubations under conditions that stimulate the action of } \\
\text { protein kinases or protein phosphatases on the } \mathrm{K}_{\mathrm{m}} \text { LA of LDH from } \\
\text { crude extracts of muscle for euthermic versus hibernating S. richardsonii }\end{array}$ & 81 \\
\hline 4.12 & $\begin{array}{l}\text { Effect of incubations under conditions that stimulate the action of } \\
\text { protein kinases or protein phosphatases on the } \mathrm{K}_{\mathrm{m}} \text { pyruvate of LDH from } \\
\text { crude extracts of muscle for euthermic versus hibernating S. richardsonii }\end{array}$ & 82 \\
\hline 4.13 & $\begin{array}{l}\text { Arrhenius plots showing the effect of temperature on liver LDH from } \\
\text { euthermic and hibernating } S \text {. richardsonii }\end{array}$ & 83 \\
\hline 4.14 & $\begin{array}{l}\text { Arrhenius plots showing the effect of temperature on muscle LDH from } \\
\text { euthermic and hibernating } S \text {. richardsonii. }\end{array}$ & 84 \\
\hline 4.15 & $\begin{array}{l}\text { Calculated activation energies }\left(\mathrm{E}_{\mathrm{a}}\right) \text { for the } \mathrm{LA} \text { utilizing direction of liver } \\
\mathrm{LDH} \text { from euthermic and hibernating } S \text {. richardsonii assayed in A) } 20 \\
\mathrm{mM} \text { phosphate buffer or B) } 20 \mathrm{mM} \text { imidazole }\end{array}$ & 85 \\
\hline 4.16 & $\begin{array}{l}\text { Calculated activation energies }\left(\mathrm{E}_{\mathrm{a}}\right) \text { for the LA utilizing direction of } \\
\text { muscle LDH from euthermic and hibernating } S \text {. richardsonii assayed in } \\
\text { A) } 20 \mathrm{mM} \text { phosphate buffer or B) } 20 \mathrm{mM} \text { imidazole }\end{array}$ & 86 \\
\hline 4.17 & $\begin{array}{l}\mathrm{K}_{\mathrm{m}} \text { LA vs temperature curves for A) liver and B) muscle LDH from } \\
\text { euthermic and hibernating } S \text {. richardsonii }\end{array}$ & 87 \\
\hline 4.18 & $\begin{array}{l}\text { Effect of high } \mathrm{KCl} \text { concentrations on } \mathrm{K}_{\mathrm{m}} \mathrm{LA} \text { of A) liver and B) muscle } \\
\mathrm{LDH} \text { from euthermic and hibernating } S \text {. richardsonii }\end{array}$ & 88 \\
\hline
\end{tabular}




\begin{tabular}{|l|l|l|}
\hline 4.19 & $\begin{array}{l}\text { Effect of high GHCl concentrations on } \mathrm{K}_{\mathrm{m}} \text { LA of A) liver and B) muscle } \\
\text { LDH from euthermic and hibernating } S \text {. richardsonii }\end{array}$ & 89 \\
\hline 4.20 & $\begin{array}{l}\text { Effect of high urea concentrations on } \mathrm{K}_{\mathrm{m}} \text { LA of A) liver and B) muscle } \\
\text { LDH from euthermic and hibernating } S \text {. richardsonii }\end{array}$ & 90 \\
\hline 4.21 & $\begin{array}{l}\text { Effect of urea on A) liver and B) muscle LDH maximal activity from } \\
\text { euthermic and hibernating } S \text {. richardsonii }\end{array}$ & 91 \\
\hline 4.22 & $\begin{array}{l}\mathrm{I}_{50} \text { values for urea inhibition of A) liver and B) muscle LDH from } \\
\text { euthermic and hibernating } S \text {. richardsonii }\end{array}$ & $\begin{array}{l}\text { Effect of incubations on urea } \mathrm{I}_{50} \text { under conditions that stimulate the } \\
\text { action of protein kinases or protein phosphatases on the } \mathrm{K}_{\mathrm{m}} \text { pyruvate of } \\
\text { LDH from crude extracts of muscle for euthermic versus hibernating } S . \\
\text { richardsonii }\end{array}$ \\
\hline 4.24 & $\begin{array}{l}\text { Effect of incubations on urea } \mathrm{I}_{50} \text { under conditions that stimulate the } \\
\text { action of protein kinases or protein phosphatases on the } \mathrm{K}_{\mathrm{m}} \text { pyruvate of } \\
\text { LDH from crude extracts of muscle for euthermic versus hibernating } S . \\
\text { richardsonii }\end{array}$ & 94 \\
\hline
\end{tabular}




\section{List of Tables}

Figure

Page

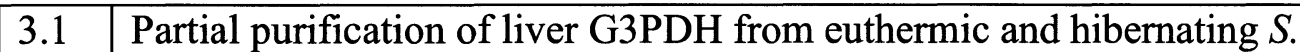
richardsonii using a hydroxyapatite column

3.2 Partial purification of muscle G3PDH from euthermic and hibernating $S$. richardsonii using a hydroxyapatite column

4.1 Partial purification of liver LDH from euthermic and hibernating $S$. richardsonii using a $\mathrm{CM}^{-}$column

4.2 Partial purification of liver LDH from euthermic and hibernating $S$. richardsonii using a $\mathrm{CM}^{-}$column 
Chapter 1

General

Introduction 
Hibernation is a survival strategy employed by many species in an effort to conserve energy in times of lowered temperatures and diminished food availability (Storey, 1997). Metabolic processes required to retain a constant core body temperature are substantial, especially when ambient temperatures are declined and therefore an elevated calorie intake is required to maintain homothermy (Carey et al., 2003). This increased calorie intake may be in vain for some animals due to a negative ratio between calorie intake versus use, a situation seen in shrews where they must constantly consume food in order to maintain energy demands (Stewart et al., 2005). A solution to combating the increased energy demand under lowered ambient temperatures is to readjust the metabolic machinery to abandon homeothermy (maintenance of constant body temperature) and embrace heterothermy (allowing body temperature to track ambient temperature). In other words, there is an uncoupling of the homothermic thermoregulatory set point of $37^{\circ} \mathrm{C}$ and a new set point established at $0^{\circ} \mathrm{C}$ which is defended. This Metabolic Rate Depression (MRD) has several characteristics in common with several hibernators and aestivators (Storey, 1997). MRD in hibernation is characterized by a lowering of normal physiological functions to a fraction of the normal rates. Overall metabolic rate is decreased to about $1-5 \%$ normal (Geiser, 2004). Heart beat is reduced from 200-300 beats per minute to 3-5 beats per minute (Zatzman, 1984), breathing rate is reduced to 6-10 breathes per minute from 100-200 breaths (McArthur and Milsom, 1991) along with several other body function rate reductions. There is also a general reduction in ATP turnover but ratios of ATP/ADP/AMP and energy charge remain close to normal levels (Storey and Storey, 2004). Since normal levels of ATP are required to maintain homothermy, the reduction in ATP turnover greatly affects the 
ability of the animal to maintain a normal homothermic core body temperature. Therefore, this thermo regulatory uncoupling subjects the animal to the ambient temperature and eventually core body temperature declines to as low as $2-10^{\circ}$, also known as torpor (Carey et al., 2003). However, if the ambient temperature decreases below $0^{\circ}$, then thermoregulatory mechanisms are activated to maintain core body temperature at or above $0^{\circ} \mathrm{C} . \mathrm{MRD}$ is also characterized by an extreme reduction in the energetically expensive transcription and translation apparatus (Storey and Storey, 2004). There is some transcription and translation during torpor but at a greatly reduced rate. Without the ability to produce new transcripts or new proteins at a significant level, existing transcripts, proteins and enzymes must be able to survive the elevated time in torpor.

There is variation in the time spent in torpor depending on the animal in question. Torpor can be short, such as few hours or overnight for a few species of birds and small mammals, to extended periods of deep torpor for groundhogs and bats extending for a few weeks (Geiser, 2004). A phenomenon for some hibernating species that endure long bouts of torpor is that they experience periods of arousal. These arousal periods lasts for about 24 hours and involve the metabolic rate excitation (MRE) back to normal euthermic levels. The reasoning for temporary MRE is unclear but several hypotheses have been put forward. One theory involves the resetting of neuronal ionic and membrane potentials. Another suggests that these arousal periods are needed for immunologic responses (Storey and Storey, 2004). Another suggests that torpor is really not a form of sleep but rather a type of sleep deprivation and that MRE is needed in order for the animal to gain the biological benefit of REM sleep (Daan et al., 1991). In fact, this theory 
has good support as EEG of hibernating squirrels show that the animal is awake during torpor and spends most of the arousal period in REM sleep. Since most mammals need sleep and are induced to sleep biochemically, such as melatonin signaling in humans that is activated at twilight or every 12-24 hours, then it stands to reason that the biochemical signal required to stimulate sleep also stimulates MRE directly or indirectly.

As previously mentioned, MRD is characterized by a lowering of transcription and translation rates. Therefore, enzymatic systems which are critical during torpor must be able to function at low temperatures and must be able to survive for long bouts of torpor. One such mechanism for the enhancement of enzymatic longevity and function at low temperature is post translational modification (PTM) where an entity is covalently attached to the enzyme, adjusting its three dimensional structure and thus extending its half life as well as altering its kinetics (Storey and Storey, 2007). Of course this is in conjunction with the evolutionary amino acid differences seen in thermal adapted enzymes (Hochachka and Somero, 1984). The most common PTM is the addition of a phosphate to a serine, threonine or tyrosine residue by a specific kinase and its removal by phosphatase. This system has the advantage of being reversible, energetically inexpensive, and fast, a situation which would be advantageous during MRE. There are several examples of reversible protein phosphorylation (RPP) in hibernation such as pyruvate kinase and pyruvate dehydrogenase complex (Storey, 1987).

The model organism used in this study was the hibernating ground squirrel Spermophilus richardsonii known commonly as the Richardson Ground Squirrel (RGS). These ground dwelling burrowing mammals have an average body mass of $0.1-0.4 \mathrm{~kg}$ and are active during the day. They burrow out dens that are 15-20 feet in length and 
reside in this burrow in a specialized chamber called the hibernaculum during the hibernation cycle. This chamber is closed off prior to hibernation and aids the RGS in maintaining the ambient temperature above freezing.

This thesis focuses on two cytosolic $\mathrm{NAD}^{+}$dependant enzymes and their possible kinetic and stability regulation by RPP during hibernation in the RGS. 
Chapter 2

Materials and Methods 


\section{Animals}

Richardson's ground squirrels, Spermophilus richardsonii, were captured in late summer and transported to the Animal Care Facility in Calgary, Alberta, Canada. All animals were individually housed in rat cages at $22^{\circ} \mathrm{C}$ in the University of Calgary animal facility. Animals had free access to food and water and were given an autumn photoperiod (10 h light, $14 \mathrm{~h}$ dark) for an 8 week period (euthermic conditions). They were allowed to feed and fatten to a body mass that would support hibernation. After this time, half of the animals were placed in a cold room at $4^{\circ} \mathrm{C}$ in the dark with free access to water but no food (hibernation conditions). These animals entered torpor within a few days and were sampled after a minimum of two days continuous torpor as determined by rectal temperatures of $5-8^{\circ} \mathrm{C}$. Euthermic controls were sampled on the same day. Both euthermic and hibernating animals were killed by decapitation and tissues were immediately harvested, frozen in liquid nitrogen and then stored at $-80^{\circ} \mathrm{C}$. Tissues were shipped to Ottawa on dry ice, and then restored at $-80^{\circ} \mathrm{C}$. Protocols used were approved by the Animal Care and Use committee of the University of Calgary.

\section{Chemicals}

Chemicals were provided from several companies and are as follows:

Invitrogen Molecular Probes: Pro Q Diamond Phospho Protein Gel Stain

Bioshop: Phenylmethylsulfonylfloride (PMSF), EDTA, EGTA, Guanidine Hydrochloride, NAD+, NADH, ADP, Potassium Chloride.

Sigma: DL- $\alpha$ Glycerol Phosphate, Sodium L-Lactate, AMP, cAMP, cGMP, Tris, Imidazole, Sodium Phosphate, Sephadex G-50 
BioRad: Hydroxyapatite Bio-Gel, Protein Assay Reagent

Polysciences: L(+) Lactic Acid

Pharmacia: CM- Sephadex

Aldrich: Sodium Orthovanadate

ABM: Rabbit G3PDH Polyclonal IgG anti-goat, Rabbit LDH Polyclonal anti-goat.

\section{Preparation of Homogenates}

All extracts were prepared by homogenizing tissues $(1: 10 \mathrm{w} / \mathrm{v}$ for liver and muscle) with an average of $0.4 \mathrm{~g}$ per preparation in ice-cold homogenizing buffer (20 $\mathrm{mM}$ imidazole $\mathrm{pH} 7.0$ containing $10 \% \mathrm{v} / \mathrm{v}$ glycerol, $30 \mathrm{mM} \mathrm{NaF}, 2.5 \mathrm{mM}$ EDTA, 2.5 mM EGTA and $10 \mathrm{mM} \beta$-mecaptoethanol and a few crystals of phenylmethylsulfonyl fluoride (PMSF) added just prior to homogenization) with a Polytron (Brinkmann Instruments) homogenizer set to full speed for 15 seconds. Homogenates were then centrifuged in a Hermle-Z $360 \mathrm{~K}$ centrifuge at $10,000 \times \mathrm{g}$ for $30 \mathrm{~min}$ at $5^{\circ} \mathrm{C}$. Supernatant fractions were collected and stored at $5^{\circ} \mathrm{C}$ until use.

\section{Determination of Enzyme Activity}

Unless otherwise stated, all assays were performed at $23.5^{\circ} \mathrm{C} \pm 0.243{ }^{\circ} \mathrm{C}$ in the oxidation direction using a Thermo Scientific Multiskan Spectrum microplate spectrophotometer (Cat \# 51118600, Vantaa, Finland). Enzyme activity was monitored in both directions by observing the reduction of $\mathrm{NAD}^{+}$or the oxidation of $\mathrm{NADH}$ at $340 \mathrm{~nm}$. Optimal assay conditions ( $\mathrm{LDH})$ for a $200 \mu 1$ well for the $\mathrm{NAD}^{+}$reduction direction were: $20 \mathrm{mM}$ phosphate $\mathrm{pH} 9.5,12.5 \mathrm{mM}$ lactic acid, $3 \mathrm{mM} \mathrm{NAD}^{+}$and $10 \mu \mathrm{L}$ of $500 \mathrm{X}$ diluted crude supernatant. Optimal assay conditions (LDH) for a $200 \mu 1$ well for the NADH 
oxidation were: $20 \mathrm{mM}$ imidazole $\mathrm{pH}$ 7.4, $0.3 \mathrm{mM} \mathrm{NADH}, 0.125 \mathrm{mM}$ pyruvate and 10 $\mu \mathrm{L}$ of 500X diluted crude supernatant. Optimal assay conditions (G3PDH) for a $200 \mu \mathrm{l}$ microplate well for the $\mathrm{NAD}^{+}$reduction direction were: $20 \mathrm{mM}$ Tris buffer $\mathrm{pH} 8.5,3 \mathrm{mM}$ $\mathrm{NAD}^{+}, 5 \mathrm{mM}$ G3P (from a $100 \mathrm{mM}$ stock) and $10 \mu \mathrm{L}$ of $100 \mathrm{X}$ crude homogenate. Optimal assay conditions (G3PDH) for a $200 \mu 1$ well for the NADH oxidation direction were: $20 \mathrm{mM}$ Tris $\mathrm{pH}$ 7.5, $0.3 \mathrm{mM}$ NADH, $0.5 \mathrm{mM}$ DHAP (from a $10 \mathrm{mM}$ stock) and 10 $\mu \mathrm{L}$ of crude homogenate. Optimal enzyme conditions, which were established after $\mathrm{pH}$ optima were found, were established for enzymes in euthermic liver and applied to other tissues. Control wells were added to account for non-specific activity and any background was subtracted from the gross activity to yield net activity values. One unit (IU) of activity is defined as the amount of enzyme that produced one $\mu$ mole of product per minute at $23^{\circ} \mathrm{C}$. Imidazole buffers were adjusted to $\mathrm{pH}$ at $23^{\circ} \mathrm{C}$ and allowed to fluctuate with temperature.

\section{Determination of pH Optima}

Velocity versus $\mathrm{pH}$ curves were generated using assays with phosphate buffer appropriate for the desired $\mathrm{pH}$ values. Optimal $\mathrm{pH}$ conditions were considered to be the $\mathrm{pH}$ in which yielded the highest activity.

\section{Spin Column to Eliminate Low Molecular Weight Molecules}

Initial supernatants were subjected to size exclusion chromatography to remove low molecular weight molecules to reduce the possibility of altered kinetics by these molecules. Aliquots of $500 \mu 1$ of $10 \mathrm{X}$ diluted supernatant were placed on $5 \mathrm{~cm}$ columns of Sephadex G-50 equilibrated in $20 \mathrm{mM}$ imidazole and spun through for $1 \mathrm{~min}$ at 2000 
$\mathrm{Xg}$ in a VWR Clinical centrifuge. Samples were then assayed and compared to control values in to assess the viability of this step.

\section{Western Blot: Total Protein Isolation}

Tissue extracts were prepared as described in Preparation of Homogenates. Samples of supernatant were diluted appropriately and measured for protein content using $10 \mu \mathrm{l}$ of diluted supernatant and $190 \mu \mathrm{l}$ of Bio-Rad Protein Assay reagent (5X dilution). After 10 min of color development, absorbance was measured at $595 \mathrm{~nm}$ in a Dynatek MR5000 Microplate Reader. Measurements were done in quadruplicate. Mean

absorbance values were used to calculate protein content from a standard curve generated using bovine serum albumin. Protein concentrations in extracts were then adjusted to a constant $5 \mu \mathrm{g} / \mathrm{ml}$ protein by the addition of small volumes of homogenization buffer, and then samples were diluted 1:1 v/v with 2X SDS-PAGE sample buffer (100 mM Tris-HCl $\mathrm{pH} 6.8,4 \% \mathrm{w} / \mathrm{v}$ SDS, $20 \% \mathrm{v} / \mathrm{v}$ glycerol, $0.4 \% \mathrm{w} / \mathrm{v}$ bromophenol blue) with $10 \% \mathrm{v} / \mathrm{v} \beta$ mecaptoethanol added. Samples were then boiled for $5-10 \mathrm{~min}$ and then frozen at $-20^{\circ} \mathrm{C}$ until use.

\section{Western Blot: Polyacrylamide Gel Electrophoresis and Immunoblotting}

SDS gels were prepared in two steps. The resolving gels (10\% acrylamide, 400 $\mathrm{mM}$ Tris $\mathrm{pH} 8.8,0.1 \% \mathrm{w} / \mathrm{v}$ SDS, $0.1 \% \mathrm{w} / \mathrm{v}$ APS, $0.04 \% \mathrm{v} / \mathrm{v}$ TEMED) were prepared with stacking gels (5\% acrylamide, $130 \mathrm{mM}$ Tris $\mathrm{pH} 6.8,0.1 \% \mathrm{w} / \mathrm{v}$ SDS, $0.1 \% \mathrm{w} / \mathrm{v}$ APS, $0.1 \% \mathrm{v} / \mathrm{v}$ TEMED). Protein loads ( $10 \mu \mathrm{l}$ of the $2.56 \mathrm{mg} / \mathrm{ml}$ stock) were separated by electrophoresis in SDS-PAGE running buffer (25 mM Tris, 190 glycine, 0.1\%w/v SDS) at $180 \mathrm{~V}$ for $50 \mathrm{~min}$. Approximate determination of protein subunit size was obtained by 
running a molecular mass ladder (Precision Plus Protein All Blue Standard, BioRad) in one lane of the gel. After electrophoresis, proteins were transferred to a PVDF membrane (Millipore, Billerica, MA) by wet transfer with pre-chilled transfer solution ( $25 \mathrm{mM}$ Tris $\mathrm{pH} 8.5,192 \mathrm{mM}$ glycine and $20 \% \mathrm{v} / \mathrm{v}$ methanol) at $4^{\circ} \mathrm{C}$ for $90 \mathrm{~min}$ at $160 \mathrm{~mA}$. Proteins on the membrane were then blocked to reduce background with $2.5 \%$ non-fat dried milk in Tris buffered saline containing Tween-20. (TBST: $20 \mathrm{mM}$ Tris, $140 \mathrm{mM} \mathrm{NaCl}, 0.05 \%$ $\mathrm{v} / \mathrm{v}$ Tween-20). After blocking, membranes were incubated with primary antibody (10,000 X dilution in TBST) overnight at $4^{\circ} \mathrm{C}$ with minimal rocking (G3PDH Polyclonal IgG anti-goat, Rabbit LDH Polyclonal anti-goat). Membranes were then washed multiple times in TBST and distilled/deionized water and incubated with secondary antibody conjugated to horseradish peroxidase (Bishop Canada) for $90 \mathrm{~min}$ at 1:5000 v/v dilutions in TBST. After washing again in TBST multiple times, signal was detected by enzymatic chemiluminescence. Mixing $1 \mathrm{ml}$ of 1:1 $\mathrm{v} / \mathrm{v}$ hydrogen peroxide and luminol reagent prior to membrane application promoted uniform exposure. Chemiluminesence was detected using the ChemiGenius Bio Imaging System (Syngene, MD, USA) with band intensity analyzed with the associated Gene Tools Software. Membranes were then stained with Coomassie blue $(0.25 \% \mathrm{w} / \mathrm{v}$ Coomassie Brilliant Blue R in 50\% v/v methanol, $7.5 \% \mathrm{v} / \mathrm{v}$ acetic acid) and then destained for 3 X 15 min with destaining solution $(60 \% \mathrm{v} / \mathrm{v}$ methanol, $20 \% \mathrm{v} / \mathrm{v}$ acetic acid in $\mathrm{ddH} 20$ ).

\section{Purification of G3PDH}

After homogenization, $1 \mathrm{ml}$ aliquots were placed on a hydroxapitite column $(5 \mathrm{~cm})$ equilibrated in $10 \mathrm{mM}$ phosphate buffer at $\mathrm{pH} 7.0$ and washed in $10 \mathrm{mM}$ phosphate buffer at pH 7.0 until wash fractions showed no G3PDH activity. The enzyme was then 
eluted from the column with a $2 \mathrm{M} \mathrm{KCl}$ gradient and fractions tested for activity. Individual fractions, which were $550 \mu \mathrm{L}$ each, were assessed and peak fractions were pooled and were subjected to the total protein isolation protocol and then $10 \mu 1$ of 121 $\mu \mathrm{g} / \mu 1$ stock was run on a SDS-PAGE as described in Western Blotting.

\section{Partial Purification of LDH}

Aliquots $(1 \mathrm{~mL})$ of crude supernatant were placed on $\mathrm{CM}$ anion exchange columns $(5 \mathrm{~cm})$ equilibrated in $20 \mathrm{mM}$ imidazole buffer $\mathrm{pH} 7.0$ and washed in imidazole buffer pH 7.0 until wash fractions showed no LDH activity. The enzyme was then eluted with a $2 \mathrm{M} \mathrm{KCl}$ gradient in imidazole buffer $\mathrm{pH} 7.0$ and fractions of $0.5 \mathrm{~mL}$ were collected and assayed for activity. Individual fractions were assessed and peak fractions were pooled and then subjected to the total protein isolation protocol and then $10 \mu 1$ of 6.7 $\mathrm{ng} / \mu 1$ stock was run on SDS-PAGE as described in Western Blotting.

\section{Pro Q Diamond Staining}

Gels were then fixed overnight ( $50 \% \mathrm{v} / \mathrm{v}$ methanol, $10 \mathrm{v} / \mathrm{v}$ acetic acid) followed by washing in $\mathrm{ddH}_{2} \mathrm{O}$ for $3 \mathrm{X} 5 \mathrm{~min}$. Pro Q Diamond Phosphorylation Gel Stain (Invitrogen, Molecular Probes) were applied in a quantity that just covered the gel. Gels were then rocked in the absence of light for $60 \mathrm{~min}$ in the stain. After washing the gels again in ddH2O for $3 \times 5 \mathrm{~min}$, destaining solution (20\% acetonitrile, $50 \mathrm{mM}$ sodium acetate, $\mathrm{pH} 4$ ) was added to the gel and rocked in the absence of light for $3 \mathrm{X} 15 \mathrm{~min}$ or until good resolution was established. Gels were then visualized for UV fluorescence in the Syngene and bands were analyzed using Gene Tools Software. A parallel gel was run identical to the Pro Q gel but this gel was subjected to staining with Coomassie blue 
$(0.25 \% \mathrm{w} / \mathrm{v}$ Coomassie Brilliant Blue $\mathrm{R}$ in $50 \% \mathrm{v} / \mathrm{v}$ methanol, $7.5 \% \mathrm{v} / \mathrm{v}$ acetic acid) and then destained for $3 \times 15$ min with destaining solution $(60 \% \mathrm{v} / \mathrm{v}$ methanol, $20 \% \mathrm{v} / \mathrm{v}$ acetic acid in $\left.\mathrm{ddH}_{2} 0\right)$.

\section{Arrhenius plots}

Both G3PDH and LDH were assayed under optimal conditions at 10-12 points over a temperature range from $0-37^{\circ} \mathrm{C}$ using a temperature controlled incubator (Thermo Scientific Model\# BOD 30A15). Enzymes were assayed in two different buffer systems, $20 \mathrm{mM}$ imidazole with $\mathrm{pH}$ adjusted to 7.4 at $23^{\circ} \mathrm{C}$ and $20 \mathrm{mM}$ phosphate with $\mathrm{pH}$ adjusted to 8.5 at $23^{\circ} \mathrm{C}$. Data were evaluated using Arrhenius plots of $\log \mathrm{V}$ versus $1 / \mathrm{K}$ and activation energies were calculated using the MPA kinetics linear least squares regression program (Brooks, 1992).

\section{I $_{50}$ Curve Generation}

Aliquots of crude supernatant were incubated in different concentrations of urea for G3PDH (1-6 M) and LDH (1-2M) at room temperature for 1.5 hours for G3PDH and 15 minutes for LDH and then subjected to assay for maximal velocity. It was assumed that the enzyme did not have significant refolding after dilution in the assay. Inhibitor concentrations that reduced enzyme activity by $50 \%$ ( $\mathrm{I}_{50}$ values) were calculated with the MPA $I_{50}$ curve program (Brooks, 1992).

\section{Total Kinase and Total Phosphatase Incubations}

Enzymes that showed differential kinetics $\left(\mathrm{K}_{\mathrm{m}}, \mathrm{V}_{\max }\right.$ or both) and/or $\mathrm{I}_{50}$ urea changes under euthermic versus hibernating states were subjected to incubation 
conditions that stimulated the activities of endogenous protein kinases or phosphatases. Crude supernatant was first centrifuged (2600 x g) through a small column of G-50 column (500 $\mu \mathrm{L}$ per $5 \mathrm{~mL}$ column) to remove low molecular weight metabolites and ions from the enzyme preparation. Aliquots of the enzyme preparation were then incubated under the following conditions:

(a) to stimulate protein kinases: $20 \mathrm{mM}$ imidazole buffer $\mathrm{pH}$ 7.0, $5 \mathrm{mM} \mathrm{Mg.ATP \text {, }}$ $30 \mathrm{mM} \mathrm{NaF}, 5 \mathrm{mM} \mathrm{Na} \mathrm{VO}_{4}, 1 \mathrm{mM}$ cAMP, $1 \mathrm{mM} \mathrm{cGMP,} 1.3 \mathrm{mM} \mathrm{CaCl}+7 \mu \mathrm{g} / \mathrm{ml}$ phorbol 12-myristate 13-acetate, $1 \mathrm{mM} \mathrm{AMP}$, and $1 \mathrm{U}$ calmodulin per tube to stimulate endogenous kinases plus the further addition of $1 \mathrm{U}$ commercial cAMP dependent Protein Kinase A (whole undisassociated rabbit enzyme) per tube,

(b) to stimulate protein phosphatases: $20 \mathrm{mM}$ imidazole buffer $\mathrm{pH} 7.0,5 \mathrm{mM}$ $\mathrm{MgCl}_{2}, 5 \mathrm{mM} \mathrm{CaCl}$ and $1 \mathrm{U}$ commercial alkaline phosphatase per tube,

(c) for a control, aliquots were diluted in stop buffer (60 mM Tris $\mathrm{pH} 8.5,90 \mathrm{mM}$ $\mathrm{NaF}, 15 \mathrm{mM}$ EDTA/EGTA, 10\% (w:v) glycerol, 30mM $\beta$-mecaptoethanol) instead of kinase or phosphatase solutions. Stop buffer was also used to quench the incubation solutions at the desired incubation time.

Samples of G3PDH were incubated for 24 hours at $4^{\circ} \mathrm{C}$, quenched, and then assayed for kinetic parameters or $\mathrm{I}_{50}$ urea stability. This method was also used to establish the effect of phosphorylation on stability to urea denaturation $\left(\mathrm{I}_{50}\right)$ for $\mathrm{LDH}$ except that samples were incubated for 48 hours at $4^{\circ} \mathrm{C}$ for $\mathrm{I}_{50}$ urea. Urea was added only after the incubations for total kinases and phosphatases.

\section{$K_{m}$ vs Temperature Curves}

Diluted crude extract was assayed in imidazole buffer pH 7.4 (LDH) or Tris 
buffer $\mathrm{pH} 8.5(\mathrm{G} 3 \mathrm{PDH})$ at variable temperatures in a temperature-controlled incubator (Thermo Scientific Model\# BOD 30A15). Microplates containing full assays minus the $\mathrm{NAD}^{+}$were equilibrated to the desired temperature for $10 \mathrm{~min}$ before $\mathrm{NAD}^{+}$was added to start the reaction. Temperature in the incubator could be variable depending on location therefore a thermocouple (Omega Microprocessor Thermometer Type J-K-T Thermocouple) was used to determine the exact temperature in a microplate well both pre- and post-assay.

\section{Denaturation Studies for Effect on Enzyme Active Site Stability}

Diluted crude extracts were assayed in the presence of potassium chloride $(\mathrm{KCl})$, guanidine hydrochloride $(\mathrm{GHCl})$ or urea at $0,0.1,0.25,0.5,1$, and $2 \mathrm{M}$ concentrations. Active site stability was assessed by changes in enzyme kinetic parameters in the presence of denaturants as compared to controls.

\section{Normalization and Statistical Analysis}

Band intensity quantification for the Pro Q gels or Western blots were performed with ChemiGenius Bio Imaging System (Syngene, MD, USA) and the accompanying software GeneTools. The Pro Q gels were normalized against the mirror Coomassie Blue stained gels for band intensity prior to quantification of the Pro $Q$ bands. All values reported are mean \pm SEM, with the number of replicate stated in the Results. Statistical testing used unpaired Student t-tests at $95 \%$ confidence; data were calculated and graphed with GraphPad Prism 5.0 software. 


\title{
Chapter 3
}

\section{Evaluation of G3PDH for}

\author{
Reversible Phosphorylation
}




\section{Introduction}

Glycerol-3-phosphate dehydrogenase (E.C. 1.1.1.8), the product of GPD1 gene (Larsson et al., 1993), is a cytosolic $77 \mathrm{kD}$ dimeric enzyme in mammals that is involved in linking fatty acid metabolism with glycolysis (Berrada et al., 2002). The enzyme is readily reversible and its mechanism involves an ordered bi-bi reaction in which glycerol3-phosphate (G3P) and $\mathrm{NAD}^{+}$are substrates in the reduction direction and dihydroxyacetone phosphate (DHAP) and NADH are substrates in the oxidative direction. During lipid oxidation, triglycerides are hydrolyzed to release free fatty acids, leaving behind the glycerol "backbone". To catabolize glycerol, it is first converted to G3P by the action of ATP-dependent glycerol kinase (E.C.2.7.1.30) (Ohira et al., 2005). G3P then has two possible fates. G3P can be converted to DHAP by cytosolic G3PDH which then introduces the 3 carbon triose-phosphate into the reactions of glycolysis or gluconeogenesis (Berg et al., 2002). G3P can also be used by the mitochondrial bound flavin-linked glycerol-3-phosphate dehydrogenase or glycerol-3-oxidase (E.C. 1.1.99.5) shuttle which allows reducing equivalents from G3P to be shunted into the electron transport chain (ETC), again yielding DHAP as a product (Fig. 3.1). This process is reversible during triglyceride biosynthesis when organs use dietary sugars to synthesize G3P and fatty acids and then assemble them into triglycerides for storage. 


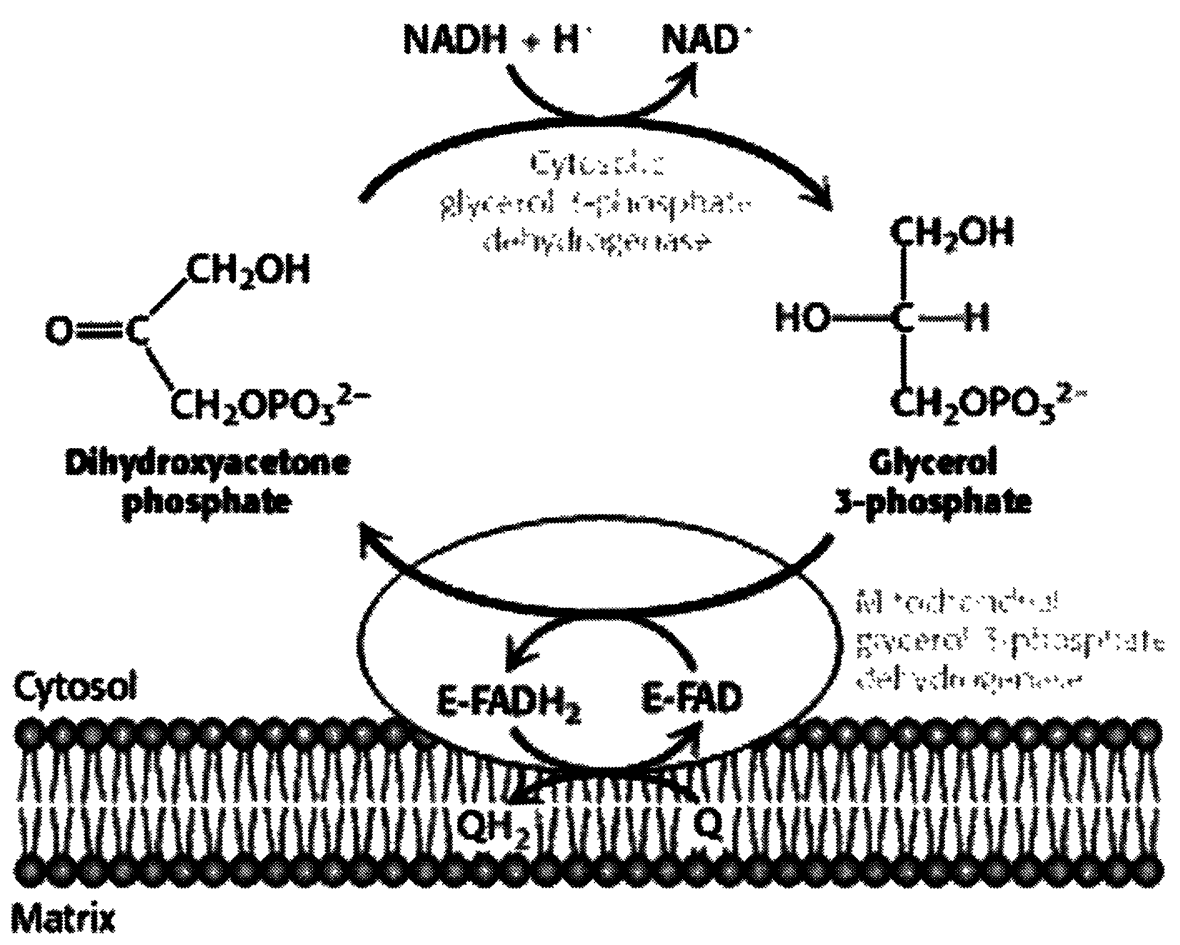

Figure 3.1: Glycerol-3-phosphate shuttle system. The mitochondrial membrane bound flavin linked G3PDH converts G3P to DHAP with simultaneous reduction of quinone to quinol and thus generating ATP via ETC. (Berg et al., 2002) 
In hibernation, it has been postulated that G3P generated during torpor, as a result of triglyceride hydrolysis, is utilized by the liver during arousal and channeled into glycolysis or gluconeogenesis as one way of replenishing glycogen stores that are possibly depleted during torpor (Galster and Morrison, 1970). It is estimated that up to $60 \%$ of G3P is converted to glycogen in liver during arousal (Galster and Morrison, 1970). These data, coupled to the suppression of glycolysis (Storey, 1987), protein breakdown (Tashima et al., 1970) and fatty acid synthesis which occurs during torpor, suggests that G3PDH is differentially regulated during hibernation and especially during the early stages of arousal.

Enzymes with regulatory functions are controlled in several ways; among them are allosteric regulation by inhibitors and activators, $\mathrm{pH}$ control, temperature sensitivity, ionic strength of surrounding media, enzyme aggregation, enzyme concentration, binding to subcellular structures and posttranslational modifications (Storey and Storey, 2004). G3PDH may be controlled via one or more of these regulators in order to modify its activity and differentially regulate G3P metabolism during euthermia versus torpor. Since G3PDH is an important link between fatty acid metabolism and glycolysis during torpor, control at this enzyme locus could be needed for a variety of reasons such as to promote the forward versus reverse direction of the enzyme under euthermic versus torpid conditions, to adjust the enzyme for function at high versus low body temperatures, or to enhance the long term stability of G3PDH over weeks of cold torpor. Post-translational modifications of G3PDH during torpor, such as by reversible protein phosphorylation, could be one key way to achieve altered kinetics, stability or half-life. Furthermore, G3PDH may be subject to different regulatory controls in different organs in order to 
achieve organ-specific needs.

\section{Hypothesis}

G3PDH, an important enzyme link between triglyceride metabolism and glycolysis during torpor, will show significantly different enzymatic properties between euthermic and torpid states resulting, at least in part, from stable posttranslational modification of the enzyme.

The present chapter examines G3PDH from liver and skeletal muscle of Richardson's ground squirrels. Studies analyze G3PDH from both euthermic and torpid animals evaluating enzyme kinetic properties in the forward and reverse directions, the effects of high and low temperature, and show that the enzyme is subject to reversible protein phosphorylation. The phosphorylation state of G3PDH changes between the euthermic and torpid state and appears to be responsible for the change in kinetic properties between the two states. 


\section{Results}

\section{pH Optimum}

After establishing a working assay, $\mathrm{pH}$ curves were generated to establish optimal $\mathrm{pH}$ conditions for the enzyme. In the G3P-utilizing direction, the optimal $\mathrm{pH}$ for highest activity was 10.0 for liver and muscle G3PDH from both euthermic and hibernating conditions (Fig. 3.2). In the DHAP-utilizing direction, the optimal pH for highest activity was 7.0 for G3PDH from both tissues and both physiological states (Fig. 3.3).

\section{Partial purification of G3PDH}

Using a hydroxyapatite column as described in the Materials and Methods, a $1 \mathrm{ml}$ aliquot of crude supernatant was placed on a $5 \mathrm{~cm}$ column equilibrated in $20 \mathrm{mM}$ phosphate $\mathrm{pH} 7.0$; the column was washed with this buffer and then enzyme was eluted with a $0-2 \mathrm{M}$ gradient of $\mathrm{KCl}$ in the same buffer. G3PDH eluted at approximately $0.6 \mathrm{M}$ $\mathrm{KCl}$ for both liver and muscle forms, as well as euthermic and hibernator forms (Fig. 3.4, 3.5). Recovery of activity was 8.25 and $11.7 \%$ for liver G3PDH from euthermic and hibernating conditions, respectively, and comparable values for muscle G3PDH were $4.1 \%$ and $3.16 \%$ (Tables $3.1,3.2$ ). This represented a 77 and 148 fold purification of liver G3PDH from euthermic and hibernating animals, respectively, and a 19.8 and 21.8 fold purification for muscle euthermic and hibernator enzyme, respectively. The specific activity of the liver euthermic form was $0.0196 \mathrm{U} / \mathrm{mg}$ protein and the hibernator form was $0.0106 \mathrm{U} / \mathrm{mg}$ protein. After the hydroxyapatite purification, the specific activity rose to 1.51 and $1.57 \mathrm{U} / \mathrm{mg}$ protein for the euthermic and hibernator forms, respectively. The specific activity of the muscle euthermic form was $0.0514 \mathrm{U} / \mathrm{mg}$ protein and the 
hibernator form was $0.0402 \mathrm{U} / \mathrm{mg}$ protein. After purification, the specific activity rose to 1.02 and $0.878 \mathrm{U} / \mathrm{mg}$ protein for the euthermic and hibernator form, respectively.

\section{Western Blotting}

To determination the relative amount of G3PDH protein in liver and muscle of ground squirrels, Western immunoblotting was used, loading $10 \mu 1$ of a $2.56 \mathrm{mg} / \mathrm{ul}$ sample per lane. G3PDH gave good bands at $\sim 37 \mathrm{kD}$, the expected subunit molecular mass of the mammalian protein (Fig. 3.6). No significant difference was seen in G3PDH protein levels in liver between euthermic and hibernating states $(\mathrm{p}=0.9452)$ or in muscle between euthermic and hibernator forms $(\mathrm{p}=0.6598)$.

\section{Phosphoprotein Staining}

To assess the relative phosphorylation state of G3PDH, partially purified enzyme from both euthermic and hibernating ground squirrels was run on SDS-PAGE (each lane had $10 \mu \mathrm{l}$ of $121 \mu \mathrm{g} / \mu \mathrm{l}$ partially purified enzyme) and then stained with ProQ Diamond phosphoprotein stain. Strong bands were seen at $\sim 37 \mathrm{kD}$ for both liver and muscle, corresponding to the position of G3PDH bands on the immunoblots (Fig. 3.7).

Quantification of band densities showed a significant difference in phosphorylation state between euthermic and hibernating conditions for both liver $(\mathrm{p}<0.0001)$ and muscle $(\mathrm{p}=0.00133)$. For both tissues, the hibernator form showed a higher content of bound phosphate.

\section{Liver G3PDH kinetic properties}

Liver G3PDH showed hyperbolic velocity versus [substrate] curves in both 
directions. Kinetic assays of liver G3PDH in the G3P-utilizing direction showed a significant difference in the $\mathrm{K}_{\mathrm{m}} \mathrm{G} 3 \mathrm{P}(\mathrm{p}=0.007, \mathrm{~N}=3$ ) (Fig. $3.8 \mathrm{~B}$ ) and no significance for the $V_{\max }(p=0.2199, N=4)$ values of G3PDH between the euthermic and hibernator forms (Fig $3.8 \mathrm{~A}$ ). The enzyme from hibernating ground squirrels showed a $\mathrm{K}_{\mathrm{m}} \mathrm{G} 3 \mathrm{P}$ of $0.24 \pm$ $0.029 \mathrm{mM}$ that was $47 \%$ lower than the euthermic value of $0.45 \pm 0.016 \mathrm{mM}$. However, enzyme $\mathrm{K}_{\mathrm{m}}$ for $\mathrm{NAD}^{+}$was not different between the two physiological states $(\mathrm{p}=0.1464$, $\mathrm{N}=4$ ) (Fig. 3.8 D). In the DHAP-utilizing direction (Fig 3.8 C), there was no significant difference in the $\mathrm{K}_{\mathrm{m}}$ for DHAP ( $\mathrm{p}=0.2872, \mathrm{~N}=4$ ) between euthermia and hibernation but there was a significant difference in the $\mathrm{V}_{\max }(\mathrm{p}=0.0021, \mathrm{~N}=4)$ representing a $12 \%$ increase in $\mathrm{V}_{\max }$ of the hibernator form (Fig 3.8 A).

\section{Muscle kinetic properties}

Assay of muscle G3PDH in the G3P utilizing direction showed a significant difference in the $K_{m}$ G3P ( $\left.<<0.0001, N=4\right)$ (Fig. 3.9 B) and the $V_{\max }(p<0.0001, N=4)$ between the euthermic and hibernator forms representing a $40 \%$ decrease in $\mathrm{K}_{\mathrm{m}}$ and a $41 \%$ decrease in the $V_{\max }$ of the hibernator form, as compared with euthermic values (Fig. 3.9 A). The affinity for $\mathrm{NAD}^{+}$was also significantly different $(p=0.002, \mathrm{~N}=4)$ between the two enzyme forms (Fig. 3.9 D), with a $66 \%$ decrease in the $\mathrm{K}_{\mathrm{m}}$ value during torpor along with the $\mathrm{V}_{\max }(\mathrm{p}<0.0001, \mathrm{~N}=4)$ representing and a $41 \%$ decrease for the hibernator form. In the DHAP utilizing direction, there was a significant difference in the $K_{m}(p=0.0065, N=4)($ Fig. $3.9 C)$ and the $V_{\max }(p<0.001, N=4)$ representing a $17 \%$ increase in $\mathrm{K}_{\mathrm{m}}$ DHAP and a $68 \%$ decrease in $\mathrm{V}_{\max }$ for the hibernator form, as compared with euthermic values. 


\section{Liver in vitro Incubations stimulating Protein Kinases or Protein Phosphatases}

The differences in kinetic properties of G3PDH between euthermic and hibernating states could result from a stable posttranslational modification of the enzyme such as by the addition or removal of covalently bound phosphate groups by protein kinases or protein phosphatases. To test this possibility, in vitro incubations were set up in which liver extracts from euthermic versus torpid squirrels were treated to conditions that stimulated either protein kinase or protein phosphatase action. The kinase conditions included Mg.ATP and second messengers of protein kinases A, C, G, AMPK and CaMK as well $1 \mathrm{U}$ of commercial PKA (whole enzyme). The phosphatase incubations included $\mathrm{MgCl}_{2}$ and $\mathrm{CaCl}_{2}$ to stimulate endogenous phosphatases as well as $1 \mathrm{U}$ commercial alkaline phosphatase. Protein kinase versus protein phosphatase treatments changed G3PDH kinetics significantly as compared to controls that were incubated in the presence of kinase and phosphatase inhibitors. When protein kinase activities were stimulated, the $K_{m}$ of the euthermic form significantly decreased $(p=0.0002, N=4)$ compared to the euthermic control, representing a 64\% increase in affinity for G3P (Figure 3.10). Furthermore, the $\mathrm{K}_{\mathrm{m}} \mathrm{G} 3 \mathrm{P}$ of the kinase-treated euthermic enzyme was not significantly different from the hibernator control value $(p=0.0982, N=4)$. Stimulation of phosphatases had the opposite effect. The $K_{m}$ of the hibernator form increased significantly $(p=0.0052$, $\mathrm{N}=4$ ) compared to the hibernator control, representing a $57 \%$ decrease in affinity for G3P and elevating the $\mathrm{K}_{\mathrm{m}}$ value to a level equivalent to that of the euthermic control. 


\section{Muscle in vitro Incubations stimulating Protein Kinases or Protein Phosphatases}

Incubations that stimulated the activities of protein kinases and protein phosphatases also changed the kinetics of muscle G3PDH significantly compared to controls. The euthermic enzyme form responded to incubations that stimulated protein kinases with a significant decrease in $K_{m} G 3 P(p=0.0439, N=4)$ compared to the control incubation, representing a $22 \%$ increase in affinity for G3P (Fig 3.11). However, kinase incubations did not affect the $\mathrm{K}_{\mathrm{m}}$ of G3PDH from hibernator muscle. By contrast, the hibernator muscle enzyme responded to protein phosphatase stimulation, the $K_{m} G 3 P$ increasing significantly $(\mathrm{p}=0.0002, \mathrm{~N}=4)$ as compared to the hibernator control incubations and representing a 57\% decrease in affinity for G3P. Phosphatase incubations also significantly elevated $\mathrm{K}_{\mathrm{m}} \mathrm{G} 3 \mathrm{P}$ of euthermic G3PDH representing a $43 \%$ decrease in G3P affinity.

\section{Arrhenius Plots and Activation Energies}

Liver: Arrhenius plots of $\log _{10} \mathrm{G} 3 \mathrm{PDH}$ activity versus $1 /{ }^{\circ} \mathrm{K} \times 10^{-3}$ yielded linear plots with no breaks for the euthermic form for assays done over the temperature range 5$37^{\circ} \mathrm{C}$. However, there was a break in the linear plot for the hibernator form in both buffer systems at approximately $15^{\circ} \mathrm{C}$ (Fig $\left.3.12 \mathrm{~A}, \mathrm{~B}\right)$. In both buffers there were significant differences in the activation energies $\left(E_{a}\right)$ between euthermic and hibernator G3PDH. For the phosphate system, values for $E_{a}$ were $14.8 \pm 0.257 \mathrm{kcal} / \mathrm{mol}$ for the euthermic form. Hibernator $\mathrm{E}_{\mathrm{a}}$ values were $10.6 \pm 0.099$ and $4.19 \pm 0.65 \mathrm{kcal} / \mathrm{mol}$ for upper and lower temperature ranges, respectively (Fig 3.14 A). For the imidazole system, values for $\mathrm{E}_{\mathrm{a}}$ were $13.7 \pm 0.193 \mathrm{kcal} / \mathrm{mol}$ for the euthermic form. Hibernator $\mathrm{E}_{\mathrm{a}}$ values were $8.70 \pm$ 
0.054 and $3.23 \pm 0.39 \mathrm{kcal} / \mathrm{mol}$ for upper and lower temperature ranges, respectively (Fig 3.14 A). There was a significant difference in $E_{a}$ in the phosphate system between euthermic and hibernator upper $(\mathrm{p}<0.0001, \mathrm{~N}=4)$ and lower $(\mathrm{p}<0.0001, \mathrm{~N}=4)$.

Significance was similar in the imidazole system between euthermic and hibernator upper $(\mathrm{p}<0.0001, \mathrm{~N}=4)$ and lower $(\mathrm{p}<0.0001, \mathrm{~N}=4)$.

Muscle: Arrhenius plots of $\log _{10} \mathrm{G} 3 \mathrm{PDH}$ activity versus $1 /{ }^{\circ} \mathrm{K}$ x $10^{-3}$ yielded linear plots with no breaks for assays done over the temperature range $5-37^{\circ} \mathrm{C}$. Both euthermic and hibernating forms showed this linear relationship in both phosphate $\mathrm{pH} 8.5$ (Fig. $3.13 \mathrm{~A}$ ) and imidazole pH 7.4 (Fig. $3.13 \mathrm{~B}$ ) buffers. In both buffers there were significant differences in the activation energies $\left(E_{a}\right)$ between euthermic and hibernator G3PDH. Values for $\mathrm{E}_{\mathrm{a}}$ were $8.79 \pm 0.058$ and $6.15 \pm 0.107 \mathrm{kcal} / \mathrm{mol}$ for euthermic and hibernator G3PDH, respectively, in phosphate buffer $\mathrm{pH} 8.5(\mathrm{p}<0.0001, \mathrm{~N}=3)$.

Comparable values were $8.31 \pm 0.072$ and $6.83 \pm 0.087 \mathrm{kcal} / \mathrm{mol}$ for euthermic and hibernator G3PDH, respectively, in imidazole pH 7.4 ( $\mathrm{p}=0.0013, \mathrm{~N}=3$ ) (Fig. $3.14 \mathrm{~B}$ ).

\section{Liver: Effect of Temperature Change on $K_{m} G 3 P$}

Changes in assay temperature had significant effects on the kinetics of euthermic and hibernator liver G3PDH that were also influenced by buffer type, Tris versus imidazole. In Tris buffer (adjusted to $\mathrm{pH} 8.5$ at $23^{\circ} \mathrm{C}$ ), the $\mathrm{K}_{\mathrm{m}} \mathrm{G} 3 \mathrm{P}$ of euthermic G3PDH was $0.912 \mathrm{mM}$ at $25^{\circ} \mathrm{C}$ and decreased significantly by $70 \%$ as temperature was reduced to $5^{\circ} \mathrm{C}(\mathrm{p}<0.0001, \mathrm{~N}=4)$ (Fig. $\left.3.15 \mathrm{~A}\right)$. Temperature also significantly affected the $\mathrm{K}_{\mathrm{m}}$ of the hibernator form which fell from $0.268 \mathrm{mM}$ at $25^{\circ} \mathrm{C}$ to $0.1 \mathrm{mM}$ at $5^{\circ} \mathrm{C}(\mathrm{p}=0.0191$, $\mathrm{N}=4$ ), representing at $63 \%$ increase in affinity for $\mathrm{G} 3 \mathrm{P}$ over the $20^{\circ} \mathrm{C}$ range. 
Similar results were seen when imidazole buffer (adjusted to $\mathrm{pH} 7.4$ at $23^{\circ} \mathrm{C}$ ) was used instead. The initial $\mathrm{K}_{\mathrm{m}}$ at $25^{\circ} \mathrm{C}$ was lower in imidazole buffer than in Tris buffer but $\mathrm{K}_{\mathrm{m}}$ again decreased significantly as temperature was dropped to $5^{\circ} \mathrm{C}(\mathrm{p}<0.001, \mathrm{~N}=4)$, representing a $62 \%$ increase in affinity for $\mathrm{G} 3 \mathrm{P}$ over a $20^{\circ} \mathrm{C}$ range (Fig. $3.15 \mathrm{~B}$ ). The $\mathrm{K}_{\mathrm{m}}$ of the hibernator form also decreased significantly as temperature was lowered from $25^{\circ} \mathrm{C}$ to $5^{\circ} \mathrm{C}(\mathrm{p}=0.0015, \mathrm{~N}=4)$, representing at $41 \%$ increase in affinity for G3P over a $20^{\circ} \mathrm{C}$ range.

\section{Muscle: Effect of Temperature Change on $K_{m}$ G3P}

Changes in assay temperature also had significant effects on the $\mathrm{K}_{\mathrm{m}} \mathrm{G} 3 \mathrm{P}$ of both the euthermic and hibernator forms of G3PDH when assayed in either Tris or imidazole buffer. In Tris buffer (adjusted to $\mathrm{pH} 8.5$ at $23^{\circ} \mathrm{C}$ ), muscle G3PDH showed a significant $32 \%$ decrease in the $\mathrm{K}_{\mathrm{m}}$ of the euthermic form as temperature was reduced from $25^{\circ} \mathrm{C}$ to $5^{\circ} \mathrm{C}(\mathrm{p}=0.0099, \mathrm{~N}=4)$ (Fig. 3.16 A). However, there was no significant difference in the $\mathrm{K}_{\mathrm{m}}$ value of the hibernator form over the $20^{\circ} \mathrm{C}$ temperature range $(\mathrm{p}=0.1689, \mathrm{~N}=4)$.

Temperature change had very distinct effect on $\mathrm{K}_{\mathrm{m}} \mathrm{G} 3 \mathrm{P}$ of the muscle enzyme when assayed in imidazole buffer (adjusted to $\mathrm{pH} 7.4$ at $23^{\circ} \mathrm{C}$ ). $\mathrm{K}_{\mathrm{m}}$ of the euthermic form was $0.471 \mathrm{mM}$ at $25^{\circ} \mathrm{C}$ and decreased to $0.0146 \mathrm{mM}$ at $5^{\circ} \mathrm{C}(\mathrm{p}<0.0001, \mathrm{~N}=4)$, a huge $97 \%$ increase in affinity for $\mathrm{G} 3 \mathrm{P}$ over the $20^{\circ} \mathrm{C}$ range (Fig. $3.16 \mathrm{~B}$ ). Hibernator showed a similar strong significant decrease in the $\mathrm{K}_{\mathrm{m}} \mathrm{G} 3 \mathrm{P}$ as temperature decreased from $25^{\circ} \mathrm{C}$ to $5^{\circ} \mathrm{C}(\mathrm{p}=0.0005, \mathrm{~N}=4)$, representing a $81 \%$ increase in affinity for $\mathrm{G} 3 \mathrm{P}$ over a $20^{\circ} \mathrm{C}$ range.

\section{Liver: Salt and Denaturant Effects on Kinetics}

The presence of high levels of $\mathrm{KCl}$, guanidine hydrochloride $(\mathrm{GHCl})$ or urea in 
the assay mixture all significantly increased the $\mathrm{K}_{\mathrm{m}} \mathrm{G} 3 \mathrm{P}$ of liver G3PDH for both euthermic and hibernating ground squirrels. As $\mathrm{KCl}$ increased from 0 to $0.5 \mathrm{M}, \mathrm{K}_{\mathrm{m}}$ of euthermic G3PDH increased by $\sim 66 \%$ whereas the $\mathrm{K}_{\mathrm{m}}$ hibernator G3PDH increased even more by $87 \%$ (Fig. 3.17 A). GHCl had strong effects at lower concentrations with $0.25 \mathrm{M} \mathrm{GHCl}$ raising $\mathrm{K}_{\mathrm{m}}$ by about $41 \%$ for euthermic and $65 \%$ for hibernator G3PDH (Fig. 3.18 A). Urea showed a similar pattern when tested over the range from 0 to $2 \mathrm{M}$ with the highest $2 \mathrm{M}$ concentration increasing $\mathrm{K}_{\mathrm{m}}$ by $60 \%$ and $84 \%$ for euthermic versus hibernating G3PDH, respectively (Fig. 3.19 A). Of note, liver G3PDH retained $\mathrm{K}_{\mathrm{m}}$ values of less than $1 \mathrm{mM}$ in the presence of up to $1 \mathrm{M}$ urea whereas $\mathrm{KCl}$ and $\mathrm{GHCl}$ retained $\mathrm{K}_{\mathrm{m}}$ values less than $1 \mathrm{mM}$ only up to about $0.25 \mathrm{M}$. G3PDH also retained some activity at higher concentrations of urea (1-2 M) compared to $\mathrm{KCl}$ and $\mathrm{GHCl}$ where there was no activity at these levels (data not shown).

The effects of long term incubation ( $90 \mathrm{~min}$ ) with urea on the activity of G3PDH were also assessed. Enzyme activity was stable at urea concentrations of less than $2 \mathrm{M}$ but decreased progressively at higher [urea] up to $6 \mathrm{M}$ (Fig $3.20 \mathrm{~A}$ ). Calculated $\mathrm{I}_{50}$ values for urea denaturation were $3.11 \pm 0.012 \mathrm{M}$ for euthermic G3PDH and significantly lower, $2.27 \pm 0.021 \mathrm{M}$, for the hibernator enzyme $(\mathrm{p}<0.0001, \mathrm{~N}=3)$ showing that the hibernator form is more susceptible to urea denaturation (Fig. 3.21 A).

\section{Muscle: Salt and Denaturant Effects on Kinetics}

$\mathrm{KCl}$, guanidine hydrochloride ( $\mathrm{GHCl})$ or urea had similar effects on muscle. G3PDH. Rising concentrations of these compounds in the assay mixture increased $\mathrm{K}_{\mathrm{m}}$ G3P and stronger effects were seen with $\mathrm{KCl}$ and $\mathrm{GHCl}$ as compared to urea. As $\mathrm{KCl}$ increased from 0 to $0.5 \mathrm{M}, \mathrm{K}_{\mathrm{m}}$ of euthermic G3PDH increased by $\sim 70 \%$ whereas the $\mathrm{K}_{\mathrm{m}}$ 
hibernator G3PDH increased even more by 78\% (Fig. 3.17 B). GHCl had strong effects at lower concentrations with $0.25 \mathrm{M} \mathrm{GHCl}$ raising $\mathrm{K}_{\mathrm{m}}$ by about $45 \%$ for euthermic and $68 \%$ for hibernator G3PDH (Fig. 3.18 B). Urea showed a similar pattern when tested over the range from 0 to $2 \mathrm{M}$ with the highest $2 \mathrm{M}$ concentration increasing $\mathrm{K}_{\mathrm{m}}$ by $59 \%$ and $61 \%$ for euthermic versus hibernating G3PDH, respectively (Fig. 3.19 B). Also, G3PDH retained $\mathrm{K}_{\mathrm{m}}$ values of less than $1 \mathrm{mM}$ up to $1 \mathrm{M}$ urea while $\mathrm{KCl}$ and $\mathrm{GHCl}$ retained $\mathrm{K}_{\mathrm{m}}$ values less than $1 \mathrm{mM}$ up to $0.25 \mathrm{M}$ denaturant. G3PDH also retained some activity at higher concentrations of urea (1-2 M) compared to $\mathrm{KCl}$ and $\mathrm{GHCl}$ where there was no activity at higher concentration.

Long term incubation of G3PDH with urea also had denaturing effects on the muscle enzyme. Enzyme activity was again stable to urea levels up to about $2 \mathrm{M}$ but then decreased progressively with incubation at higher [urea] up to $6 \mathrm{M}$ (Fig 3.20 B).

Calculated $\mathrm{I}_{50}$ values for urea denaturation were $4.40 \pm 0.009 \mathrm{M}$ for euthermic G3PDH and significantly lower, $3.91 \pm 0.012 \mathrm{M}$, for the hibernator enzyme $(\mathrm{p}<0.0001, \mathrm{~N}=3)$. As for liver, this indicated that the hibernator form was more susceptible to urea denaturation (Fig $3.21 \mathrm{~B})$. 
pH Optima: G3P Utilizing Direction:

$\mathbf{A}$

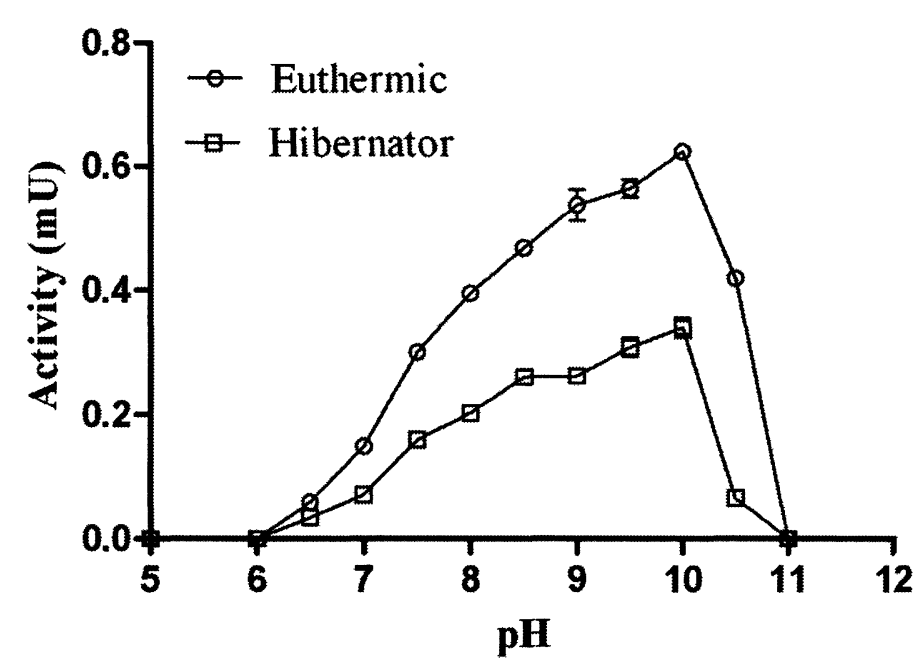

B

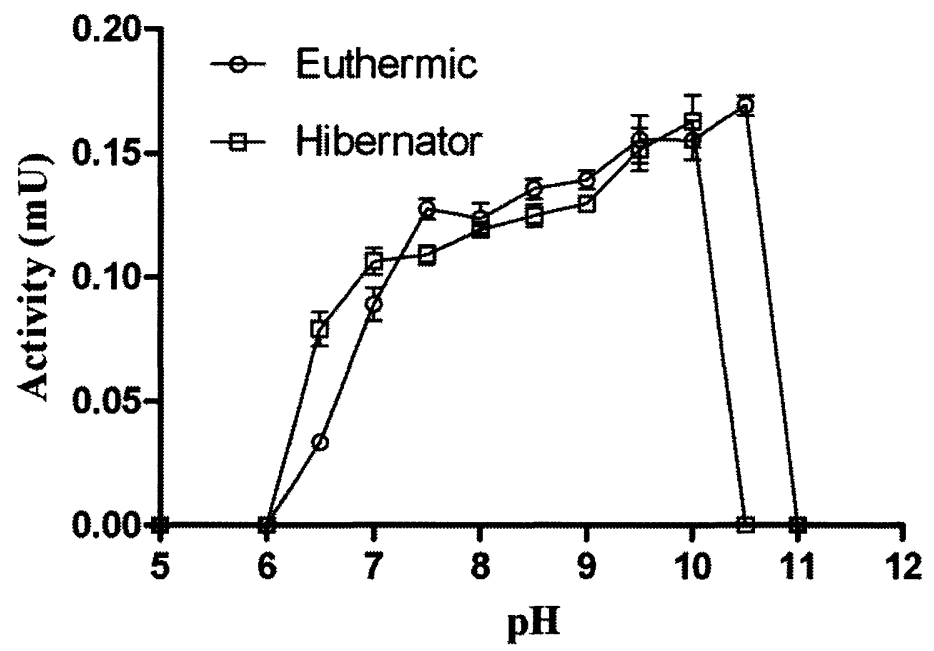

Figure 3.2: Effect of $\mathrm{pH}$ on G3PDH activity from A) liver and B) muscle of euthermic and hibernating ground squirrels. Assay conditions for a $200 \mu 1$ well in the G3P-utilizing direction: $20 \mathrm{mM}$ phosphate buffer, $3 \mathrm{mM} \mathrm{NAD}+10 \mathrm{mM} \mathrm{G} 3 \mathrm{P}$, and $10 \mu 1$ of crude supernatant (100X dilution). Phosphate buffer was used as the $\mathrm{pH}$ ranges from 5-11. 
A

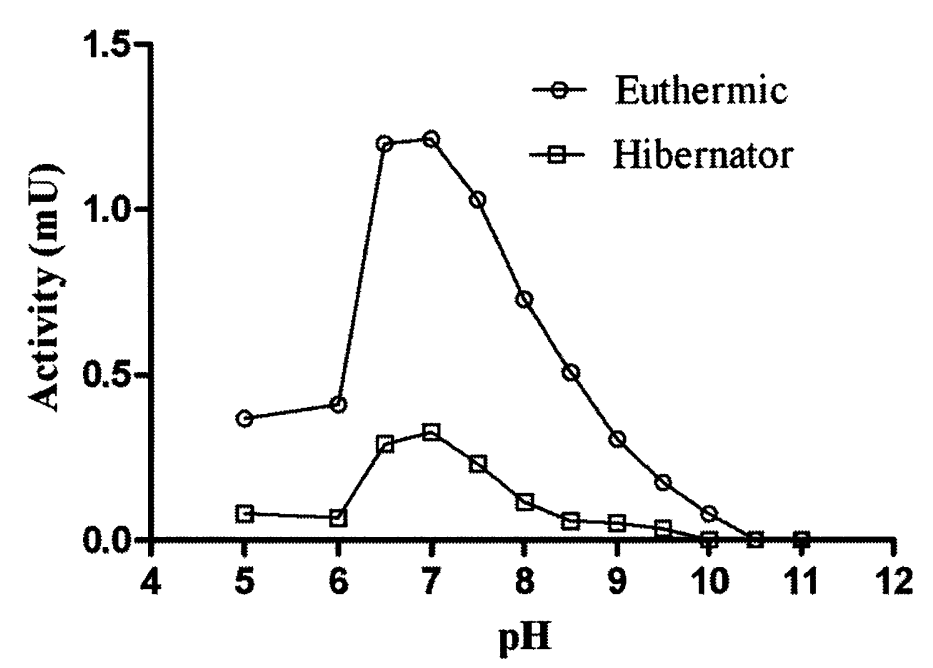

B

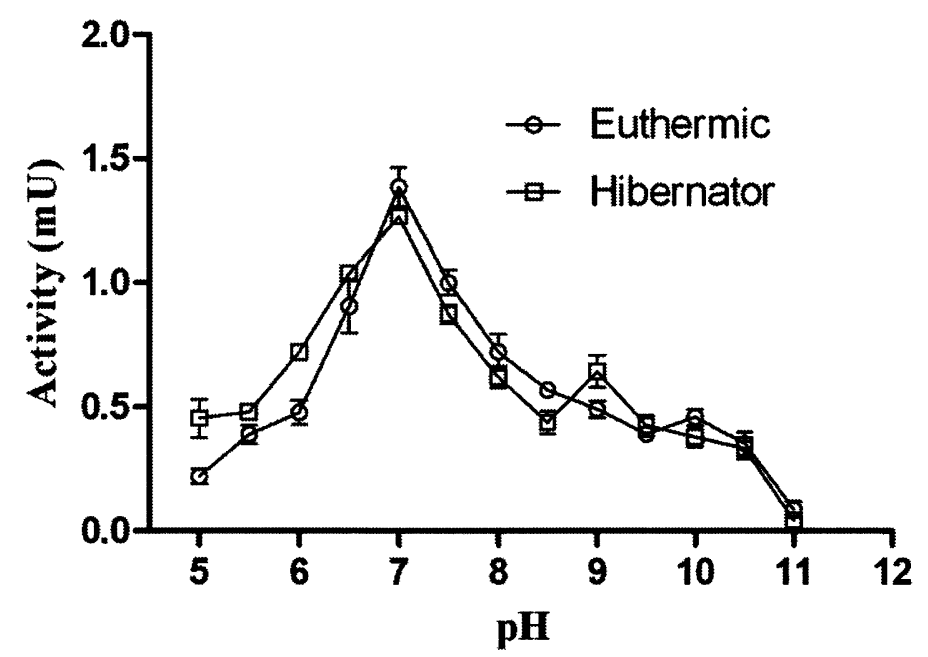

Figure 3.3: Effect of $\mathrm{pH}$ on G3PDH activity from A) liver and B) muscle of euthermic and hibernating ground squirrels. Assay conditions for a $200 \mu 1$ well in the DHAPutilizing direction: $20 \mathrm{mM}$ phosphate buffer, $0.263 \mathrm{mM} \mathrm{NADH}, 0.5 \mathrm{mM}$ DHAP and 10 $\mu \mathrm{l}$ of crude supernatant (100X dilution). Phosphate buffer was used as the $\mathrm{pH}$ ranges from 5-11. 


\section{Partial Purification: Liver}

Table 3.1: Partial purification of liver G3PDH from euthermic and hibernating $S$. richardsonii using a hydroxyapatite column.

\begin{tabular}{|c|c|c|c|c|c|}
\hline $\begin{array}{c}\text { Purification } \\
\text { Step }\end{array}$ & $\begin{array}{c}\text { Total } \\
\text { Protein } \\
(\mathrm{mg})\end{array}$ & Activity (U) & $\begin{array}{c}\text { Yield } \\
(\%)\end{array}$ & $\begin{array}{c}\text { Fold } \\
\text { Purification }\end{array}$ & $\begin{array}{c}\text { Specific } \\
\text { Activity } \\
(\mathrm{U} / \mathrm{mg})\end{array}$ \\
\hline Euthermic & & & & & \\
\hline Crude & $225 \pm 5.59$ & $4.41 \pm 0.05$ & $\mathrm{NA}$ & $\mathrm{NA}$ & 0.0196 \\
\hline Hydroxyapatite & $0.241 \pm 0.006$ & 0.364 & 8.25 & 77 & 1.51 \\
\hline Hibernator & & & & & \\
\hline Crude & $331 \pm 3.46$ & $3.52 \pm 0.09$ & $\mathrm{NA}$ & $\mathrm{NA}$ & 0.0106 \\
\hline Hydroxyapatite & $0.263 \pm 0.003$ & 0.413 & 11.7 & 148 & 1.57 \\
\hline
\end{tabular}

A

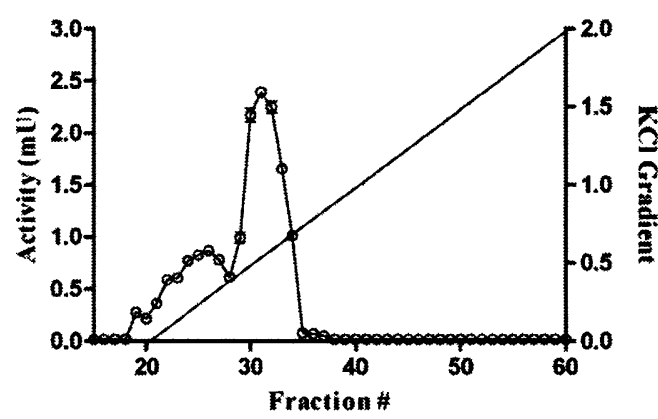

B

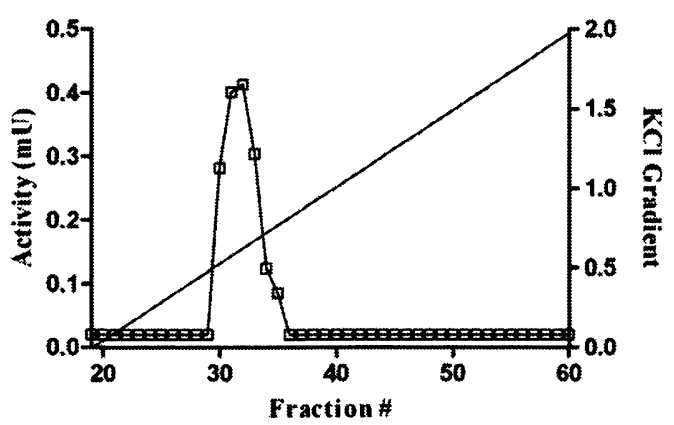

Figure 3.4: G3PDH elution profiles off a hydroxyapatite column. (A) euthermic liver, (B) hibernator liver. After the addition of $1 \mathrm{ml}$ of crude extract, the column was washed with $20 \mathrm{mM}$ phosphate buffer $\mathrm{pH} 7$ (euthermic: fraction \#0-23, hibernator: fraction 0-18) until no G3PDH activity was detected. Enzyme was then eluted with a 0-2 $\mathrm{M} \mathrm{KCl}$ gradient in the same buffer. Assay conditions for a $200 \mu \mathrm{l}$ well in the G3P-utilizing direction: $20 \mathrm{mM}$ Tris buffer $\mathrm{pH} 8.5,3 \mathrm{mM} \mathrm{NAD}^{+}, 10 \mathrm{mM} \mathrm{G} 3 \mathrm{P}$, and $10 \mu 1$ of eluted fraction. 


\section{Partial Purification: Muscle}

Table 3.2: Partial purification of muscle G3PDH from euthermic and hibernating $S$. richardsonii using a hydroxyapatite column.

\begin{tabular}{|c|c|c|c|c|c|}
\hline $\begin{array}{c}\text { Purification } \\
\text { Step }\end{array}$ & $\begin{array}{c}\text { Total } \\
\text { Protein } \\
(\mathrm{mg})\end{array}$ & $\begin{array}{c}\text { Total } \\
\text { Activity } \\
(\mathrm{U})\end{array}$ & $\begin{array}{c}\text { Yield } \\
(\%)\end{array}$ & $\begin{array}{c}\text { Fold } \\
\text { Purification }\end{array}$ & $\begin{array}{c}\text { Specific } \\
\text { Activity } \\
(\mathrm{U} / \mathrm{mg})\end{array}$ \\
\hline Euthermic & & & & & \\
\hline Crude & $155 \pm 16.0$ & $7.96 \pm 0.114$ & $\mathrm{NA}$ & $\mathrm{NA}$ & 0.0514 \\
\hline Hydroxyapatite & $0.318 \pm 0.035$ & 0.327 & 4.10 & 19.8 & 1.02 \\
\hline Hibernator & & & & & \\
\hline Crude & $181 \pm 12.8$ & $7.28 \pm 0.065$ & $\mathrm{NA}$ & $\mathrm{NA}$ & 0.0402 \\
\hline Hydroxyapatite & $0.262 \pm 0.037$ & 0.230 & 3.16 & 21.8 & 0.878 \\
\hline
\end{tabular}

$\mathbf{A}$

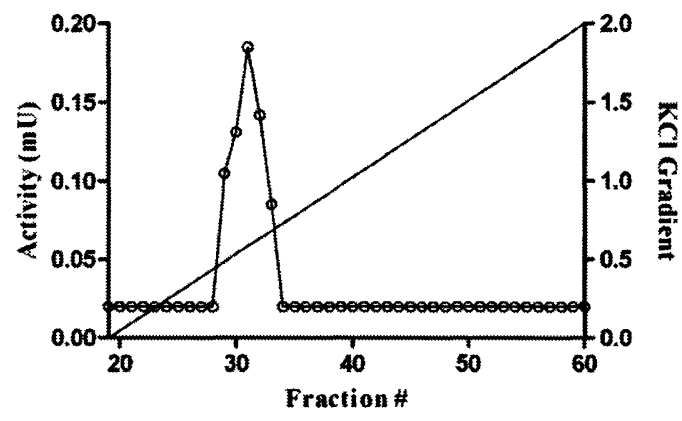

B

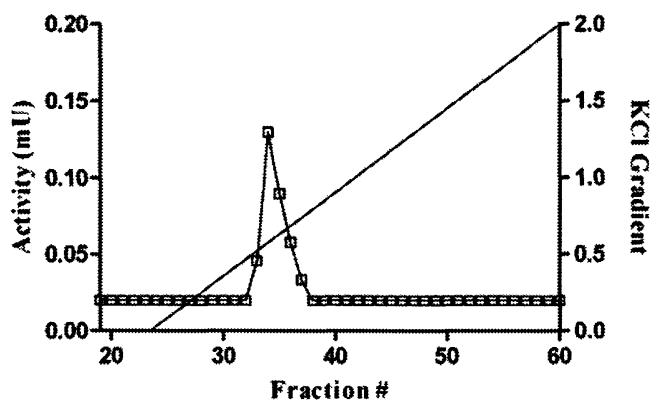

Figure 3.5: G3PDH elution profiles off a hydroxyapatite column (A) euthermic muscle,

(B) hibernator muscle. After the addition of $1 \mathrm{ml}$ of crude extract, the column was washed with $20 \mathrm{mM}$ phosphate buffer $\mathrm{pH} 7$ (euthermic: fraction \#0-18, hibernator: fraction 0-20) until no G3PDH activity was detected. Enzyme was then eluted with a 0-2

$\mathrm{M} \mathrm{KCl}$ gradient in the same buffer. Assay conditions for a $200 \mu 1$ well in the G3Putilizing direction: $20 \mathrm{mM}$ Tris buffer $\mathrm{pH} 8.5,3 \mathrm{mM} \mathrm{NAD}^{+}, 10 \mathrm{mM} \mathrm{G} 3 \mathrm{P}$, and $10 \mu 1$ of eluted fraction. 


\section{Western Blots:}

A

Euthermic $\quad \sim 37 k D \quad$ Hibernator

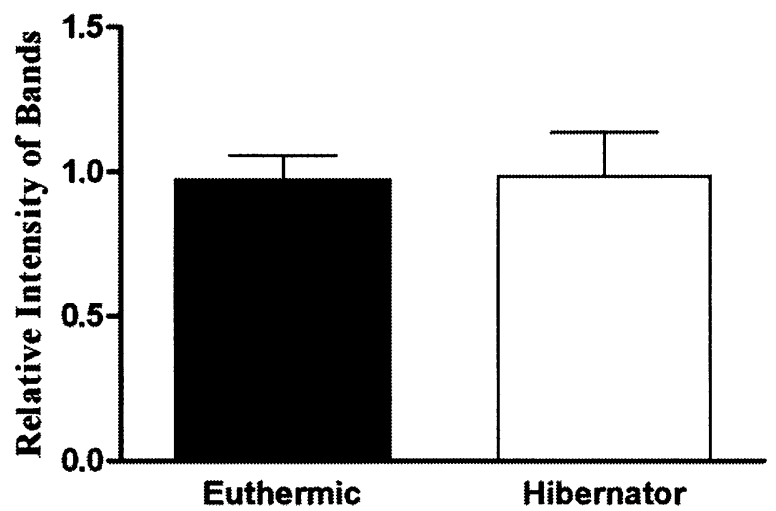

B

Euthermic $\quad \sim 37 k D \quad$ Hibernator
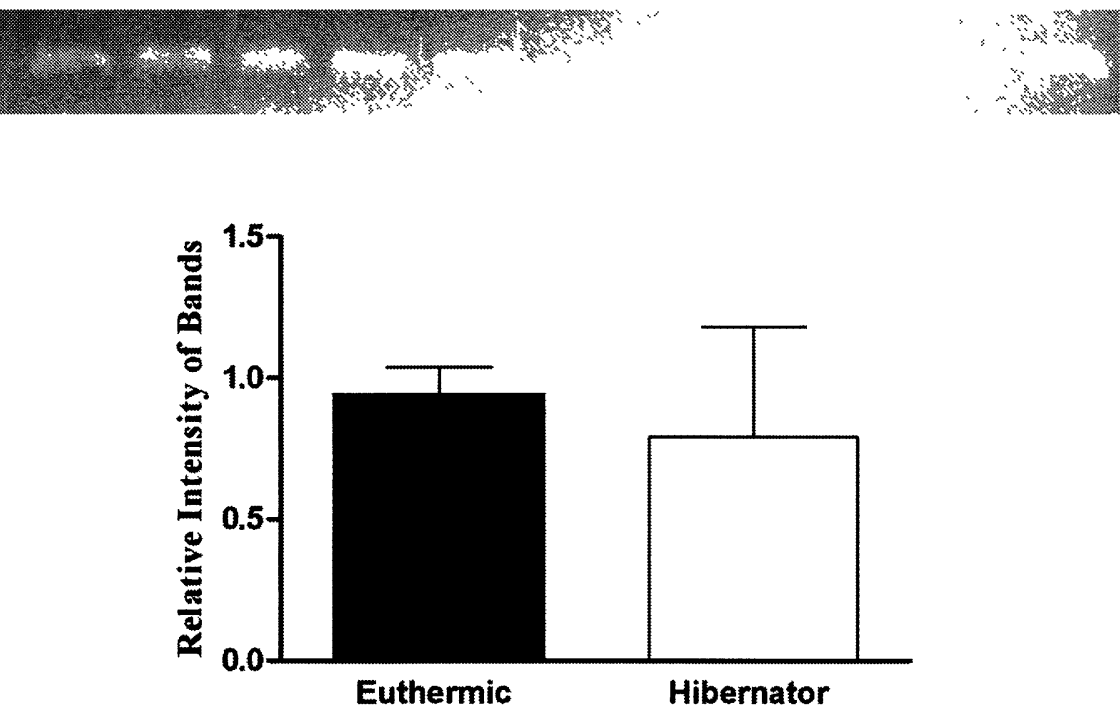

Figure 3.6: Western blotting assessing G3PDH protein levels in (A) liver and (B) muscle of euthermic versus hibernating $S$. richardsonii. There was no significant difference between G3PDH protein content between the two states in either liver $(p=0.9452)$ or $(p=0.6598)$. Lanes were loaded with $10 \mu \mathrm{l}$ of a $2.56 \mathrm{mg} / \mathrm{ul}$ from crude extracts. Data are means $\pm \mathrm{SEM}, \mathrm{N}=3$ biological replicates, $\mathrm{N}=5$ technical replicates per biological replicate. 
Pro Q Diamond Phosphoprotein Staining:

A

Euthermic $\sim 37$ kD Hibernator
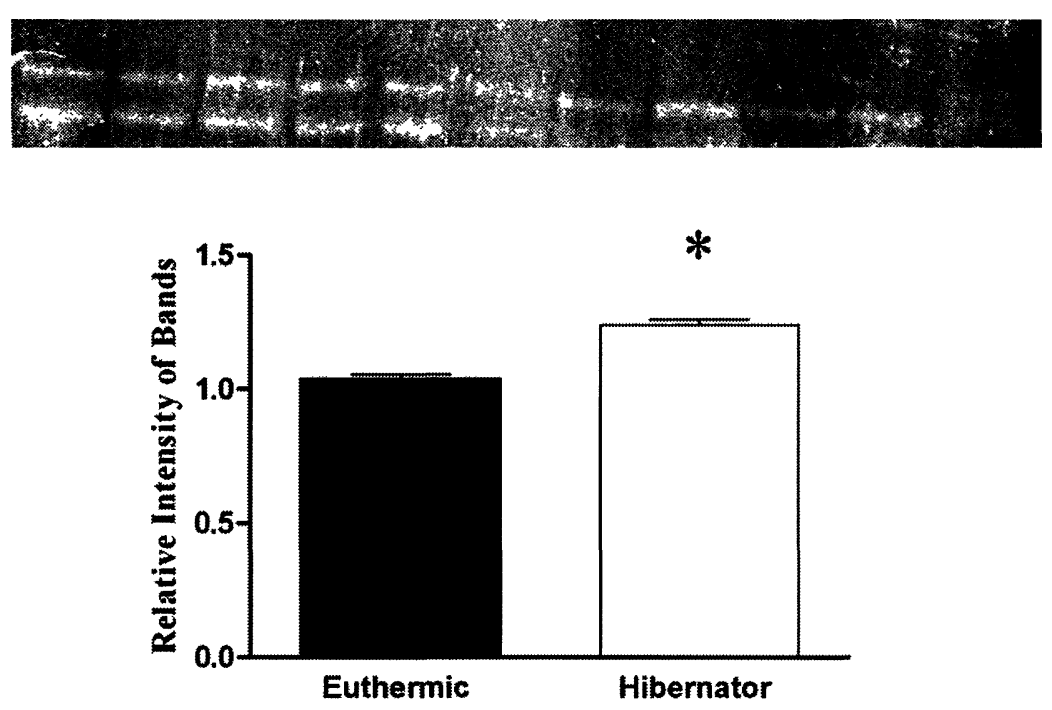

B

Euthermic $\sim 37 \mathrm{kD} \quad$ Hibernator
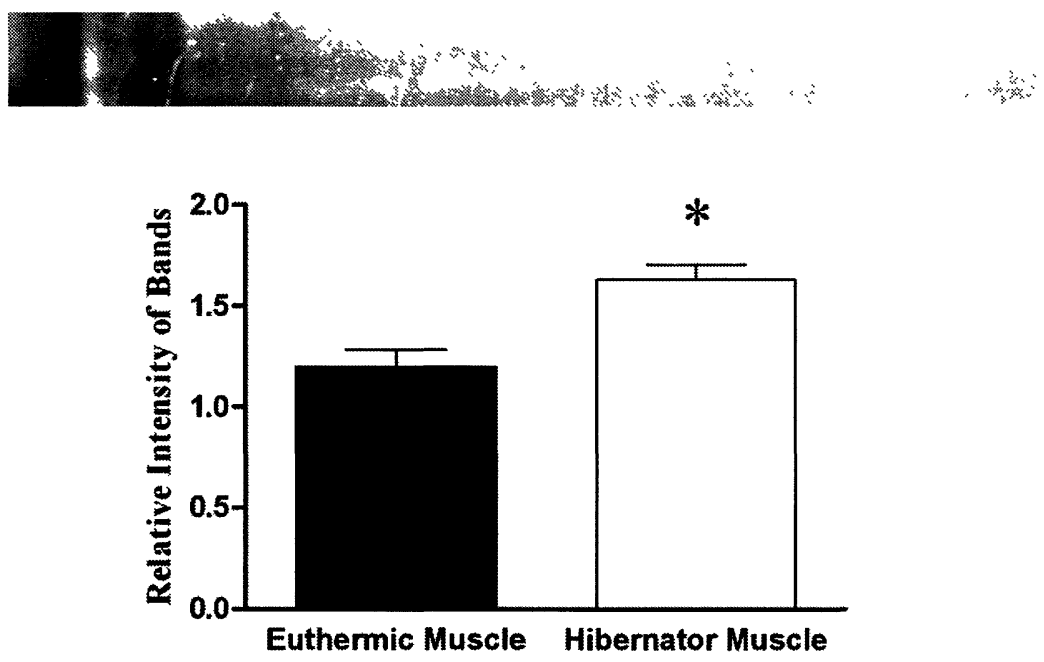

Figure 3.7: Relative amount of phosphorylated G3PDH as detected by ProQ Diamond staining in samples of partial purified enzyme from (A) liver and (B) muscle of euthermic and hibernating $S$. richardsonii. There is a significant difference in phosphorylation between states for liver $(p<0.0001)$ and muscle $(p=0.0133)$ with the hibernator being more phosphorylated in both cases. Lanes were loaded with $10 \mu 1$ of $121 \mathrm{ng} / \mu 1$ partially purified enzyme. Data are means $\pm \mathrm{SEM}, \mathrm{N}=5$. 
Kinetics: Liver

$\mathbf{A}$

\begin{tabular}{|c|c|c|c|}
\hline Parameter & Euthermic & Hibernator & Significant Difference \\
\hline \multicolumn{4}{|l|}{ LIVER } \\
\hline $\mathrm{V}_{\max }$ DHAP (U/gww) & $386 \pm 6.8$ & $441 \pm 8.2$ & Yes \\
\hline$K_{m}$ DHAP, $\mathbf{m M}$ & $0.35 \pm 0.041$ & $0.413 \pm 0.03$ & No \\
\hline$V_{\max }$ G3P (U/gww) & $67 \pm 1.8$ & $71 \pm 2.3$ & No \\
\hline $\mathrm{K}_{\mathrm{m}} \mathrm{G} 3 P, \mathrm{mM} 23^{\circ} \mathrm{C}$ & $0.45 \pm 0.016$ & $0.24 \pm 0.029$ & Yes \\
\hline $\mathbf{K}_{\mathrm{m}} \mathrm{NAD}^{+}, \mathbf{m M}$ & $1.00 \pm 0.084$ & $1.20 \pm 0.083$ & Yes \\
\hline $\mathrm{K}_{\mathrm{m}} \mathrm{G3P}, \mathrm{mM} 25^{\circ} \mathrm{C}$ & $0.91 \pm 0.003$ & $0.27 \pm 0.034$ & Yes \\
\hline $\mathrm{K}_{\mathrm{m}} \mathrm{G3P}, \mathrm{mM} \mathrm{5}^{\circ} \mathrm{C}$ & $0.28 \pm 0.038$ & $0.10 \pm 0.041$ & Yes \\
\hline $\begin{array}{c}\mathrm{E}_{\mathrm{a}}\left(\mathrm{kcal} \mathrm{mol}^{-1}\right) \\
\text { Low Temp }\end{array}$ & $14.8 \pm 0.257$ & $4.19 \pm 0.651$ & Yes \\
\hline$I_{50}$ Urea, $\mathbf{M}$ & $3.11 \pm 0.012$ & $2.27 \pm 0.021$ & Yes \\
\hline
\end{tabular}

B

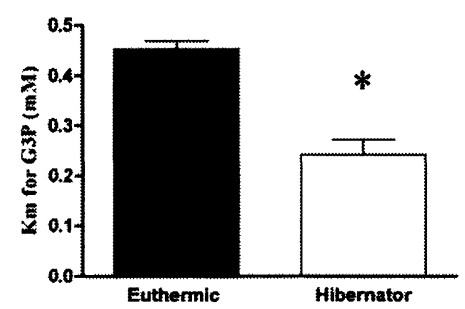

C

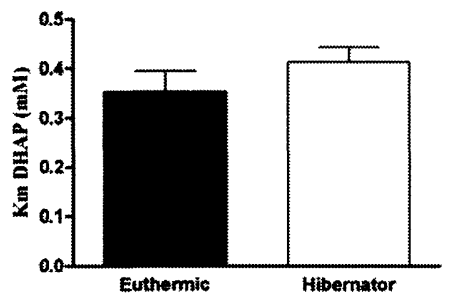

D

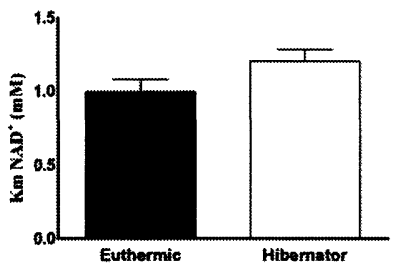

Figure 3.8: Kinetic parameters of liver G3PDH from euthermic and hibernating $S$. richardsonii showing $\mathrm{A}$ ) kinetic values for several kinetic variables with significant differences listed. Specifically, there is a significant difference between euthermic and hibernator $\mathrm{G} 3 \mathrm{P} \mathrm{K}_{\mathrm{m}}(\mathrm{B}: \mathrm{p}=0.0007)$, and no significant differences between euthermic and hibernator DHAP $K_{m}(C: p=0.2872)$ or $\mathrm{NAD}^{+} \mathrm{K}_{\mathrm{m}}(\mathrm{D}: \mathrm{p}=0.1464)$. Data are means $\pm \mathrm{SEM}$, $\mathrm{N}=4$. 
Kinetics: Muscle

A

\begin{tabular}{|c|c|c|c|}
\hline Parameter & Euthermic & Hibernator & Significant Difference \\
\hline \multicolumn{4}{|l|}{ MUSCLE } \\
\hline$V_{\max }$ DHAP (U/gww) & $357 \pm 14$ & $115 \pm 6$ & Yes \\
\hline $\mathbf{K}_{\mathrm{m}}$ DHAP, $\mathbf{m M}$ & $0.43 \pm 0.017$ & $0.52 \pm 0.012$ & Yes \\
\hline$V_{\max } G 3 P(U / g w w)$ & $90 \pm 1.9$ & $53.5 \pm 1.7$ & Yes \\
\hline $\mathrm{K}_{\mathrm{m}} \mathbf{G 3 P}, \mathbf{m M} 23^{\circ} \mathrm{C}$ & $0.48 \pm 0.010$ & $0.29 \pm 0.008$ & Yes \\
\hline $\mathbf{K}_{\mathrm{m}} \mathbf{N A D}^{+}, \mathbf{m M}$ & $1.12 \pm 0.013$ & $0.410 \pm 0.048$ & Yes \\
\hline $\mathrm{K}_{\mathrm{m}} \mathbf{G 3 P}, \mathbf{m M ~} 25^{\circ} \mathrm{C}$ & $0.436 \pm 0.018$ & $0.214 \pm 0.025$ & Yes \\
\hline $\mathrm{K}_{\mathrm{m}} \mathbf{G 3 P}, \mathrm{mM} \mathrm{5}^{\circ} \mathrm{C}$ & $0.30 \pm 0.034$ & $0.17 \pm 0.017$ & Yes \\
\hline $\mathrm{E}_{\mathrm{a}}\left(\mathrm{kcal} \mathrm{mol}^{-1}\right)$ & $8.31 \pm 0.072$ & $6.83 \pm 0.087$ & Yes \\
\hline$I_{50}$ Urea, $M$ & $4.40 \pm 0.009$ & $3.91 \pm 0.012$ & Yes \\
\hline
\end{tabular}

B

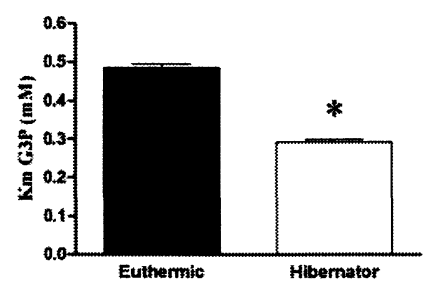

C

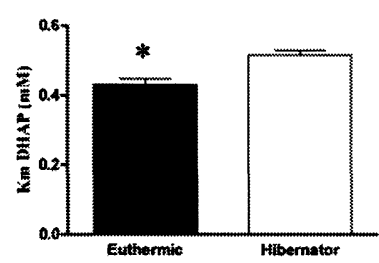

D

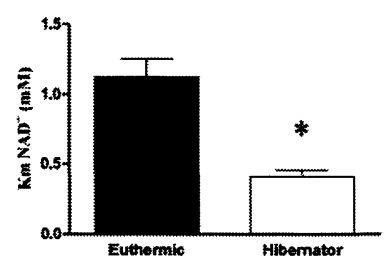

Figure 3.9: Kinetic parameters of skeletal muscle G3PDH from euthermic and hibernating $S$. richardsonii showing A) kinetic values for several kinetic variables with significant differences listed. Specifically, there is a significant difference between euthermic and hibernator G3P $K_{m}(B: p<0.0001)$, DHAP $K_{m}(C: p=0.0065)$ and NAD ${ }^{+}$ $K_{m}(D: p=0.002)$. Data are means $\pm S E M, N=4$. 


\section{Kinetics: Incubations G3P Direction Liver:}

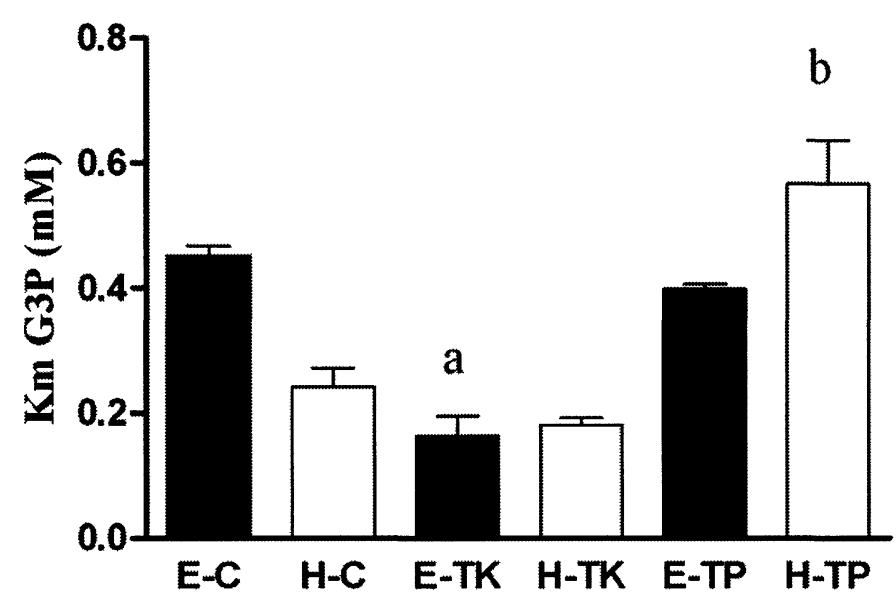

Figure 3.10: Effect of incubations under conditions that stimulate the action of protein kinases or protein phosphatases on the $\mathrm{K}_{\mathrm{m}} \mathrm{G} 3 \mathrm{P}$ of G3PDH from crude extracts of liver for euthermic versus hibernating $S$. richardsonii (See Methods for incubation conditions). Kinase conditions both stimulated endogenous protein kinases and contained $1 \mathrm{U}(10 \mu \mathrm{l})$ commercial PKA enzyme. Conditions are: $\mathrm{E}-\mathrm{C}=$ Euthermic Control, $\mathrm{H}-\mathrm{C}=$ Hibernator

Control, E-TK = Euthermic Total Kinase, H-TK = Hibernator Total Kinase, E-TP = Euthermic Total Phosphatase and H-TP = Hibernator Total Phosphatase. Upon kinase stimulation, $\mathrm{Km}$ values for euthermic G3PDH were significantly reduced (a: $\mathrm{p}=0.0002$ ) compared to euthermic controls. After phosphatase stimulation, hibernator $\mathrm{Km}$ values increased significantly ( $b: p=0.0052$ ) compared to hibernator controls. Data are means \pm $\mathrm{SEM}, \mathrm{N}=4$. 


\section{Kinetics: Incubations G3P Direction Muscle:}

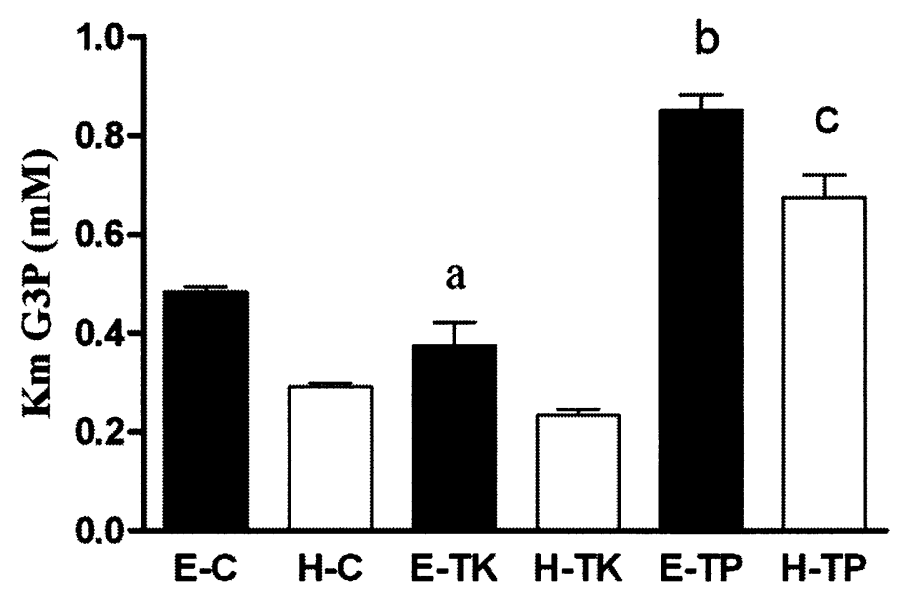

Figure 3.11: Effect of incubations under conditions that stimulate the action of protein kinases or protein phosphatases on the $\mathrm{K}_{\mathrm{m}} \mathrm{G} 3 \mathrm{P}$ of G3PDH from crude extracts of muscle for euthermic versus hibernating $S$. richardsonii (See Methods for incubation conditions). Kinase conditions both stimulated endogenous protein kinases and contained $1 \mathrm{U}(10 \mu 1)$ commercial PKA enzyme. Conditions are: $\mathrm{E}-\mathrm{C}=$ Euthermic Control, $\mathrm{H}-\mathrm{C}=$ Hibernator

Control, E-TK = Euthermic Total Kinase, H-TK = Hibernator Total Kinase, E-TP = Euthermic Total Phosphatase and H-TP = Hibernator Total Phosphatase. Upon kinase stimulation, $K_{m}$ values for euthermic G3PDH were significantly reduced ( $a: p=0.0439$ ) compared to euthermic controls. After phosphatase stimulation, euthermic and hibernator $\mathrm{K}_{\mathrm{m}}$ values increased significantly ( $\mathrm{b}: \mathrm{p}<0.0001, \mathrm{c}: \mathrm{p}=0.0002$ ) compared to euthermic controls. Data are means $\pm \mathrm{SEM}, \mathrm{N}=4$. 


\section{Arrhenius Plots and Activation Energies:}

\section{Liver:}

A

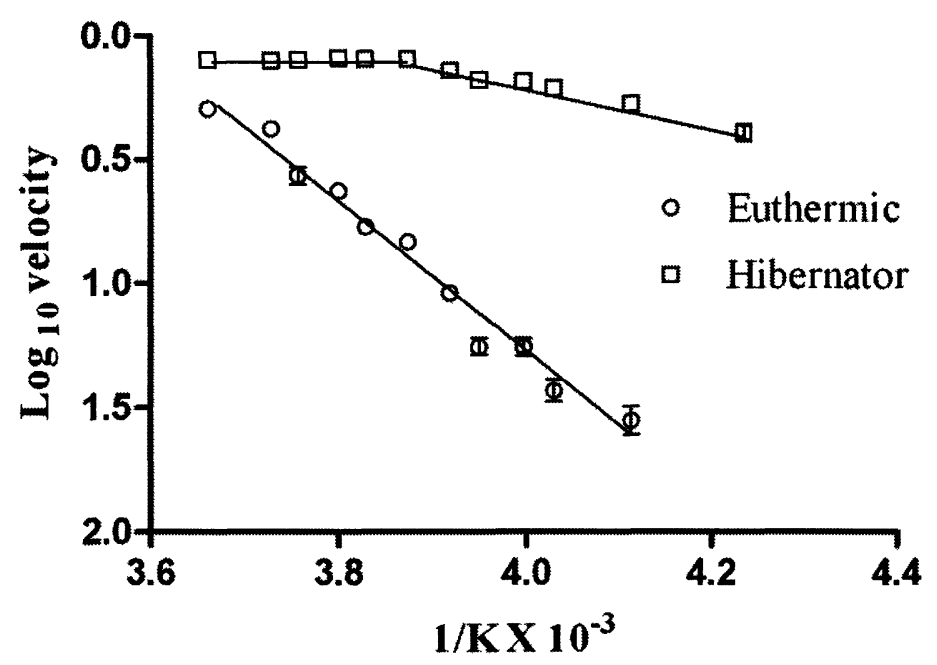

B

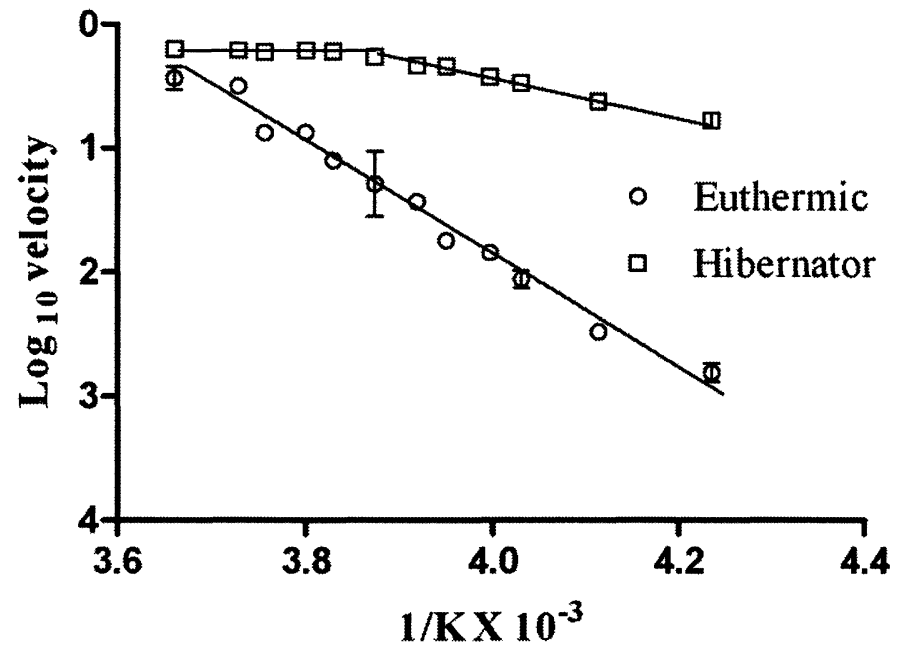

Figure 3.12: Arrhenius plots showing the effect of temperature on liver G3PDH from euthermic and hibernating $S$. richardsonii. Assay conditions for a $200 \mu 1$ well: (A) 20 $\mathrm{mM}$ phosphate buffer (adjusted to $\mathrm{pH} 8.5$ at $23^{\circ} \mathrm{C}$ ), and (B) $20 \mathrm{mM}$ imidazole buffer (adjusted to $\mathrm{pH} 7.4$ at $23^{\circ} \mathrm{C}$ ) each with $3 \mathrm{mM} \mathrm{NAD}^{+}, 10 \mathrm{mM} \mathrm{G} 3 \mathrm{P}, 20 \mu \mathrm{L}$ of $100 \mathrm{X}$ crude supernatant. Imidazole and phosphate buffers were allowed to fluctuate with temperature.

Data are means $\pm \mathrm{SEM}, \mathrm{N}=4$. 


\section{Arrhenius Plots and Activation Energies:}

\section{Muscle:}

$\mathbf{A}$

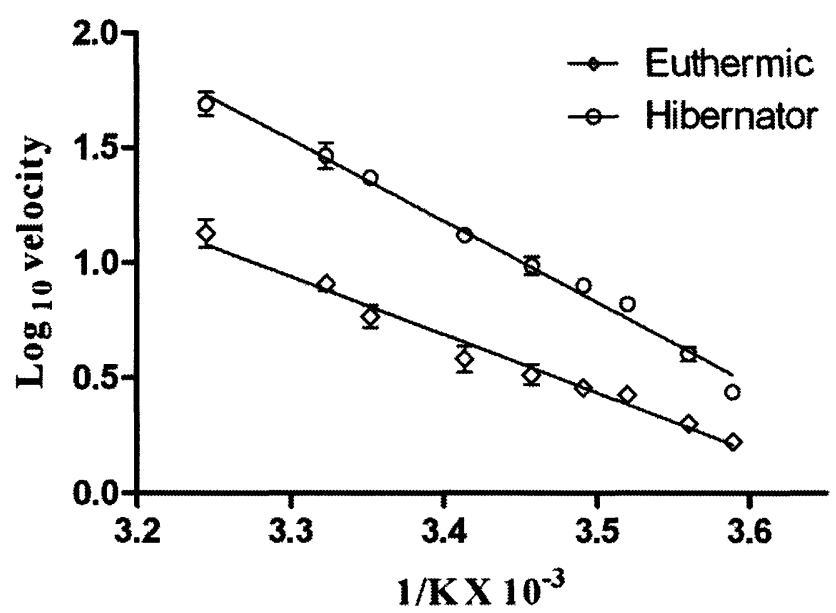

B

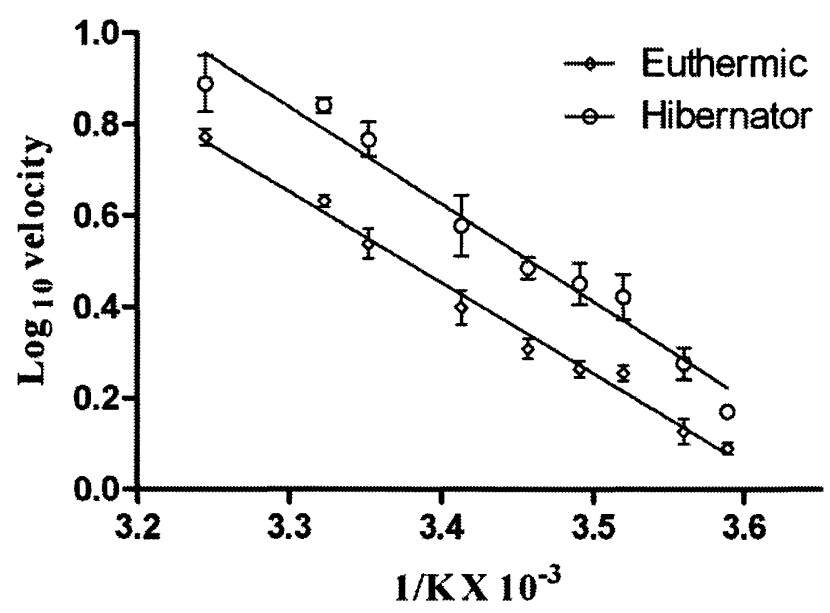

Figure 3.13: Arrhenius plots showing the effect of temperature on muscle G3PDH from euthermic and hibernating $S$. richardsonii. Assay conditions for a $200 \mu$ l well: (A) 20 $\mathrm{mM}$ phosphate buffer (adjusted to $\mathrm{pH} 8.5$ at $23^{\circ} \mathrm{C}$ ), and (B) $20 \mathrm{mM}$ imidazole buffer (adjusted to $\mathrm{pH} 7.4$ at $23^{\circ} \mathrm{C}$ ) each with $3 \mathrm{mM} \mathrm{NAD}^{+}, 10 \mathrm{mM} \mathrm{G} 3 \mathrm{P}, 20 \mu \mathrm{L}$ of $100 \mathrm{X}$ crude supernatant. Imidazole and phosphate buffer was allowed to fluctuate with temperature.

Data are means $\pm \mathrm{SEM}, \mathrm{N}=4$. 
$\mathbf{A}$

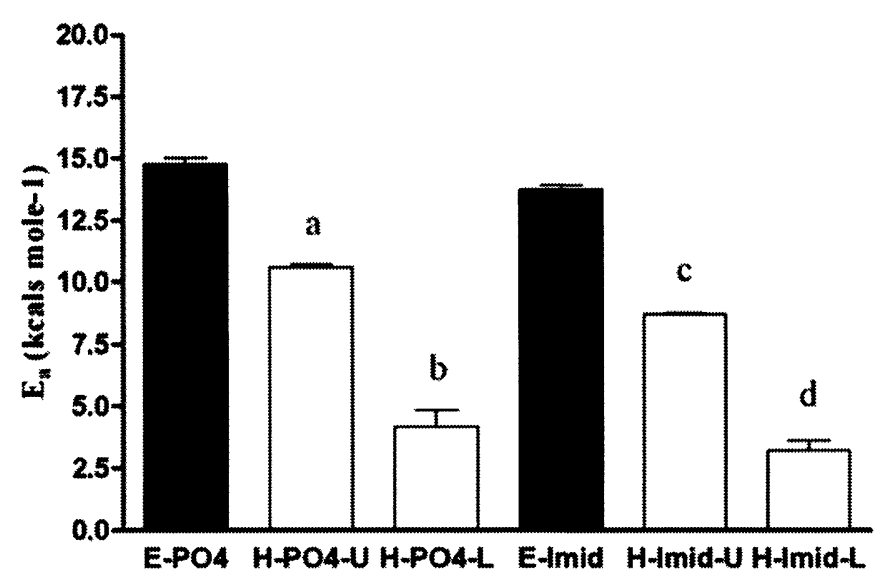

B

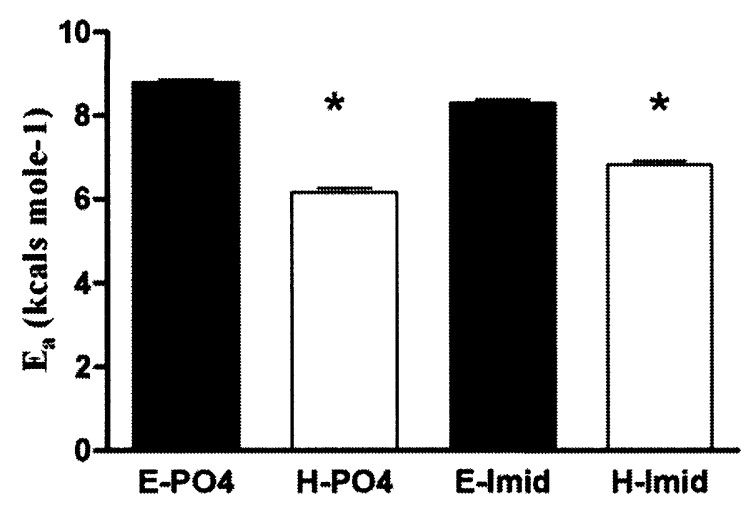

Figure 3.14: Calculated activation energies $\left(E_{a}\right)$ for the G3P utilizing direction of $A$ ) liver and B) muscle G3PDH from euthermic and hibernating $S$. richardsonii assayed in $20 \mathrm{mM}$ phosphate buffer ( $\mathrm{pH}^{\prime} \mathrm{d}$ to 8.5 at $23^{\circ} \mathrm{C}$ ) or $20 \mathrm{mM}$ imidazole (pH'd to 7.4 at $23^{\circ} \mathrm{C}$ ). Both buffers were allowed to change $\mathrm{pH}$ with temperature. Significant differences occurred between euthermic and hibernator $E_{a}$ values in both tissues and in Ea between hibernator upper and lower temperature changes (above/below $\left.15^{\circ} \mathrm{C}\right)(\mathrm{a}: \mathrm{p}<0.0001, \mathrm{~N}=4)$. There is also a significant difference between euthermic and hibernator upper range (b: $p<0.0001$, $\mathrm{N}=4$ ). Muscle forms show significant differences between euthermic and hibernator $E_{a}$ in both phosphate buffer $(\mathrm{p}<0.0001, \mathrm{~N}=4)$ and imidazole $(\mathrm{p}<0.0001, \mathrm{~N}=4)$ denoted by *

Data are means \pm SEM, N=3. E-PO4 = Euthermic in Phosphate buffer, H-PO4-U = Hibernator in Phosphate buffer upper, H-PO4-L = Hibernator in Phosphate buffer lower, E-Imid = Euthermic in Imidazole buffer and H-Imid-U = Hibernator in Imidazole buffer upper, H-Imid-L = Hibernator in Imidazole buffer lower. 
Km vs Temperature Curves: Tris Buffer:

A

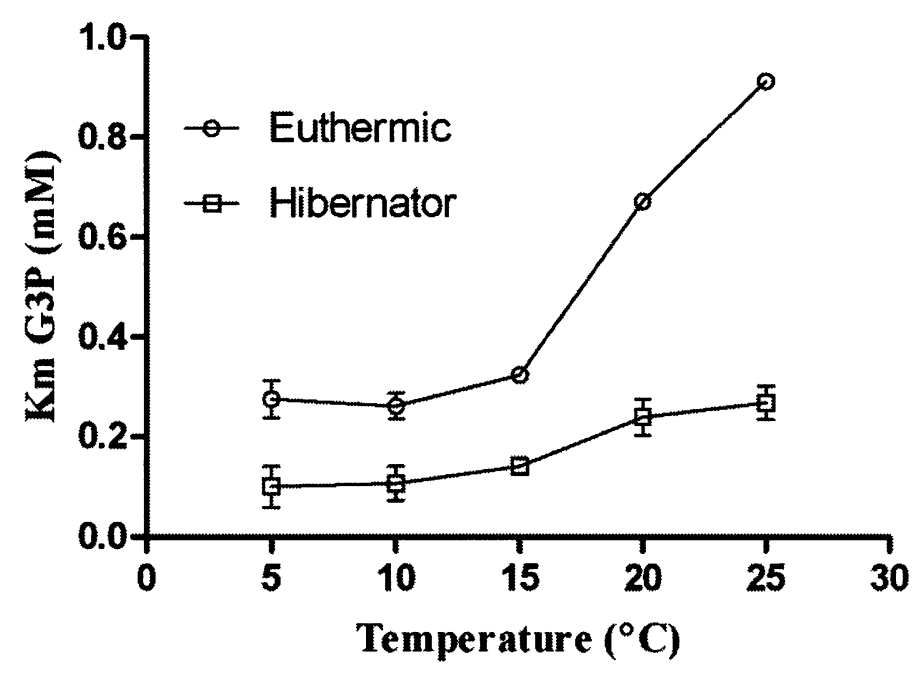

B

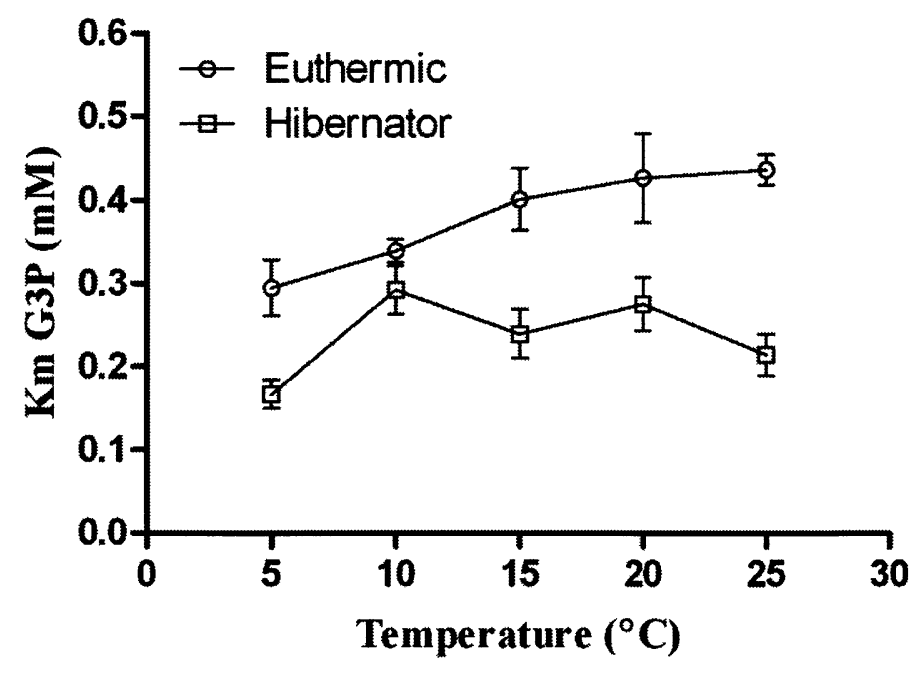

Figure 3.15: $\mathrm{K}_{\mathrm{m}}$ G3P vs temperature curves for A) liver and B) muscle G3PDH from euthermic and hibernating $S$. richardsonii. Assays were performed in Tris buffer adjusted to $\mathrm{pH} 8.5$ at $23^{\circ} \mathrm{C}$ and allowed to fluctuate with temperature. Assay conditions for a 200 $\mu \mathrm{L}$ well were: $20 \mathrm{mM}$ Tris $\mathrm{pH} 8.5,3 \mathrm{mM} \mathrm{NAD}^{+}$, various concentrations of G3P and 10 $\mu \mathrm{L}$ of $100 \mathrm{X}$ diluted crude supernatant. Data are means $\pm \mathrm{SEM}, \mathrm{N}=4$ 


\section{Km vs Temperature Curves: Imidazole Buffer:}

A

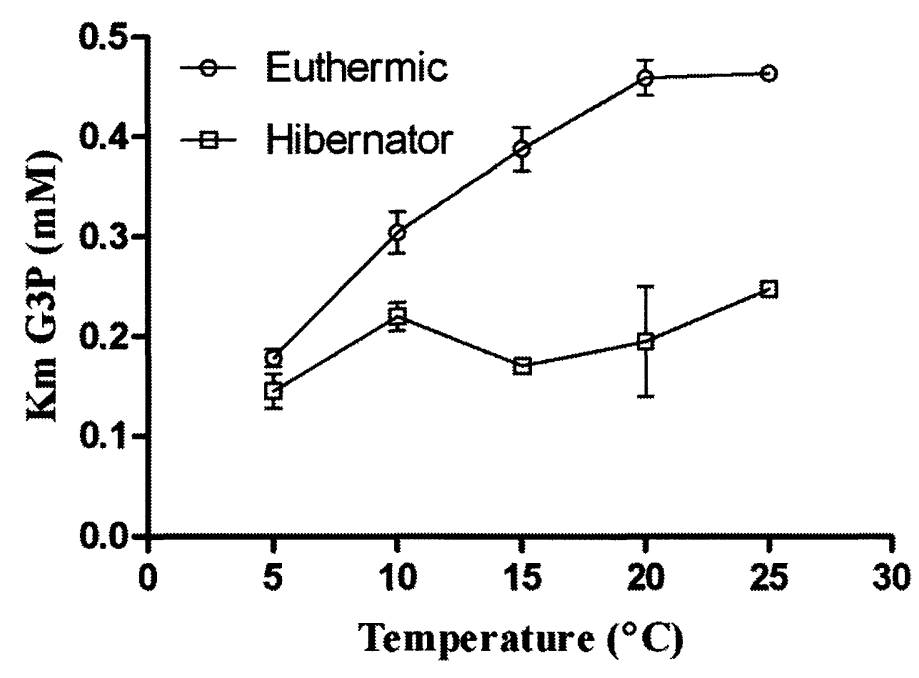

B

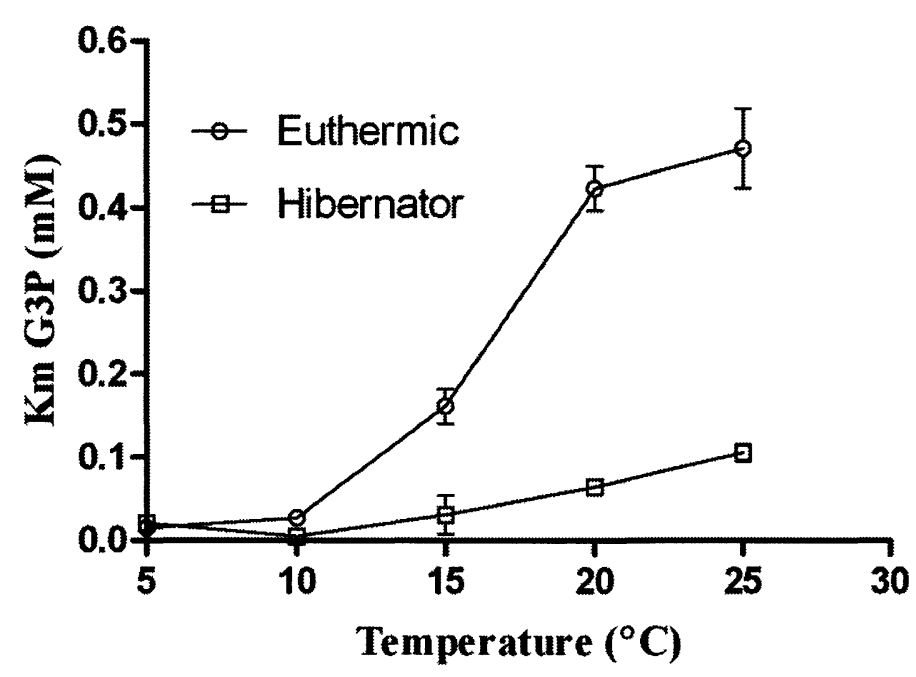

Figure 3.16: Km G3P vs temperature curves for A) liver and B) muscle G3PDH from euthermic and hibernating $S$. richardsonii. Assays were performed in imidazole buffer adjusted to $\mathrm{pH} 7.4$ at $23^{\circ} \mathrm{C}$ and allowed to fluctuate with temperature. Assay conditions

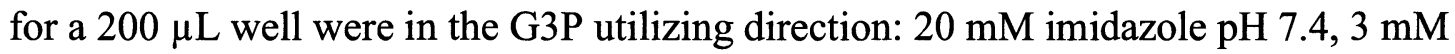
$\mathrm{NAD}^{+}$, various concentrations of G3P and $10 \mu \mathrm{L}$ of $100 \mathrm{X}$ diluted crude supernatant. Data are means $\pm \mathrm{SEM}, \mathrm{N}=4$. 


\section{KCl Effects on $K_{m} G 3 P$}

$\mathbf{A}$

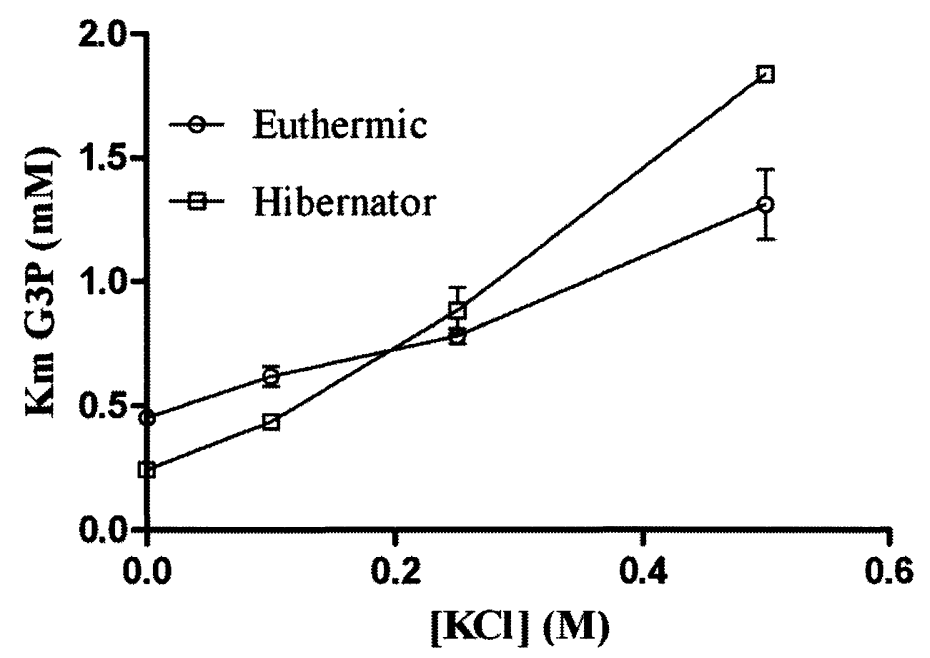

B

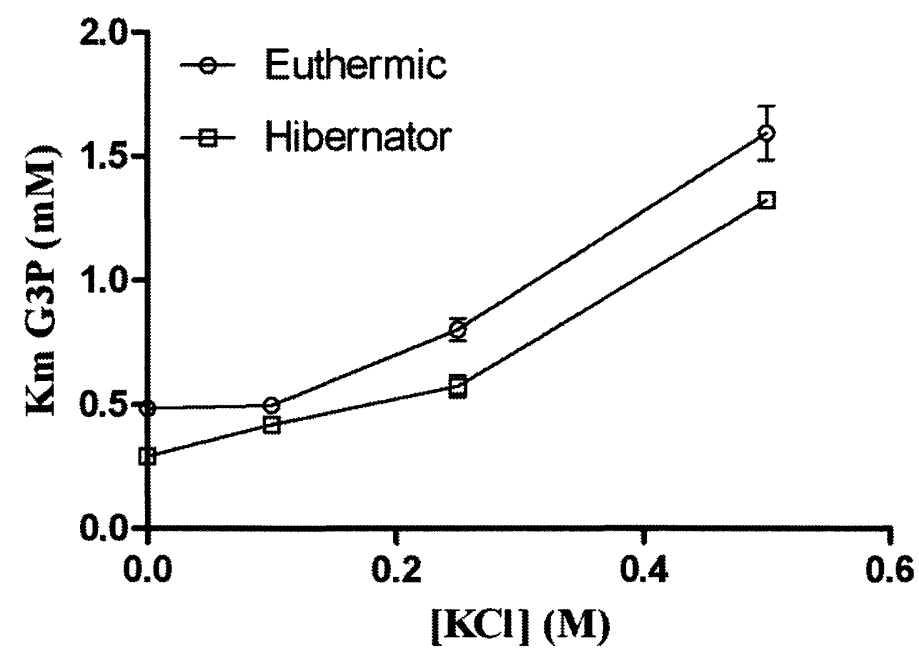

Figure 3.17: Effect of high $\mathrm{KCl}$ concentrations on $\mathrm{K}_{\mathrm{m}} \mathrm{G} 3 \mathrm{P}$ of $\mathrm{A}$ ) liver and $\mathrm{B}$ ) muscle G3PDH from euthermic and hibernating $S$. richardsonii. Assays were performed in Tris buffer adjusted to $\mathrm{pH} 8.5$ at $23^{\circ} \mathrm{C}$. Assay conditions for a $200 \mu \mathrm{L}$ well at $23^{\circ} \mathrm{C}$ were: 20 $\mathrm{mM}$ Tris $\mathrm{pH} 8.5,3 \mathrm{mM} \mathrm{NAD}^{+}$, variable amounts of G3P, $10 \mu \mathrm{L}$ of $100 \mathrm{X}$ diluted crude supernatant and 0-2 $\mathrm{M} \mathrm{KCl}$. Data are means $\pm \mathrm{SEM}, \mathrm{N}=3$. 


\section{GHCl Effects on $K_{m} G 3 P$}

A

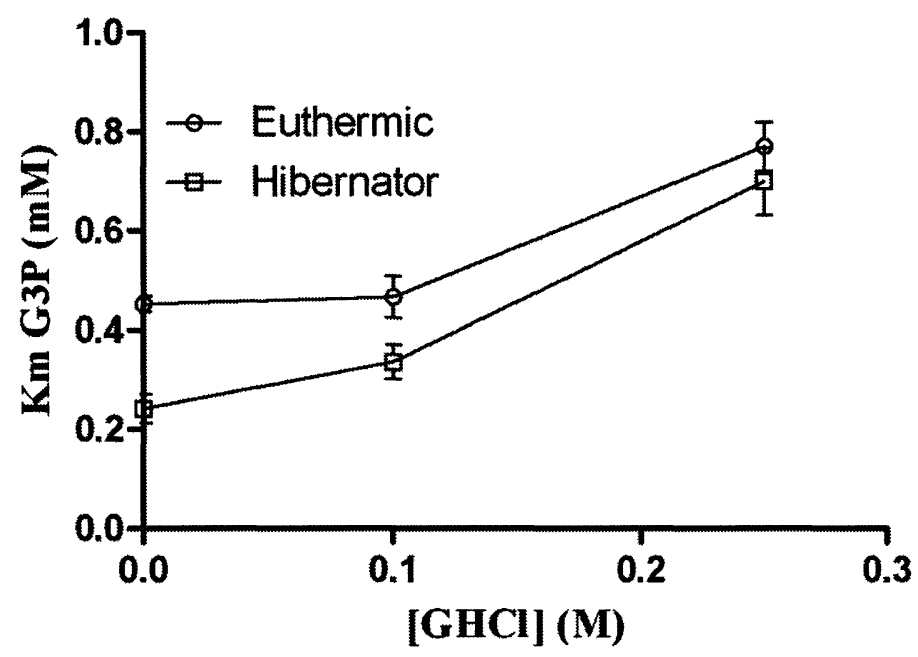

B

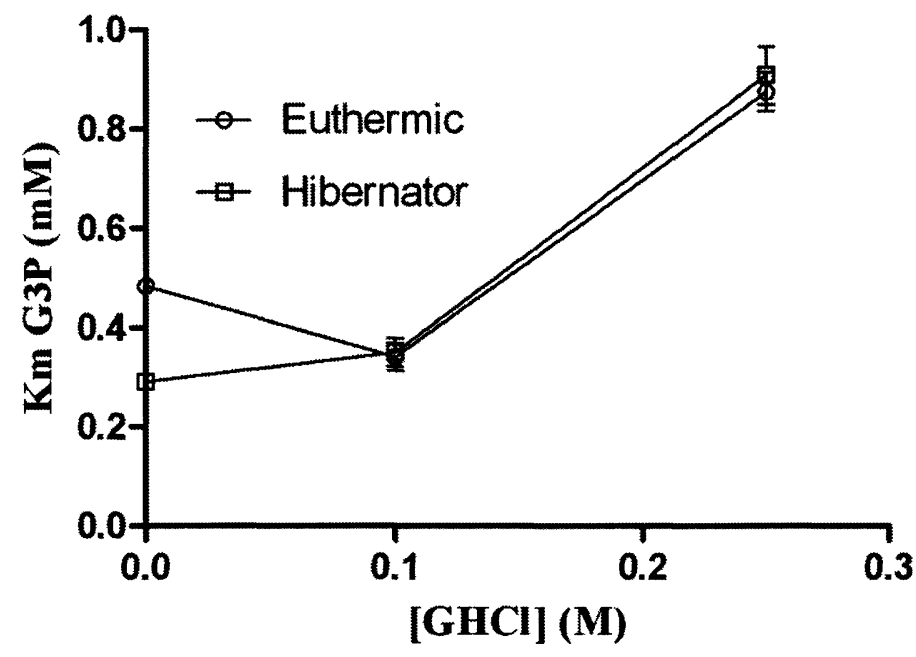

Figure 3.18: Effects of guanidine hydrochloride on $\mathrm{K}_{\mathrm{m}} \mathrm{G} 3 \mathrm{P}$ of A) liver and B) muscle G3PDH from euthermic and hibernating $S$. richardsonii. Assays were performed in Tris buffer adjusted to $\mathrm{pH} 8.5$ at $23^{\circ} \mathrm{C}$. Assay conditions for a $200 \mu \mathrm{L}$ well were: $20 \mathrm{mM}$ Tris, $3 \mathrm{mM} \mathrm{NAD}^{+}$, variable amounts of G3P, $10 \mu \mathrm{L}$ of $100 \mathrm{X}$ diluted crude supernatant and $0-2$ $\mathrm{M} \mathrm{GHCl}$. Data are means \pm SEM, $\mathrm{N}=3$. 
Urea Effects on $K_{m} G 3 P$

A

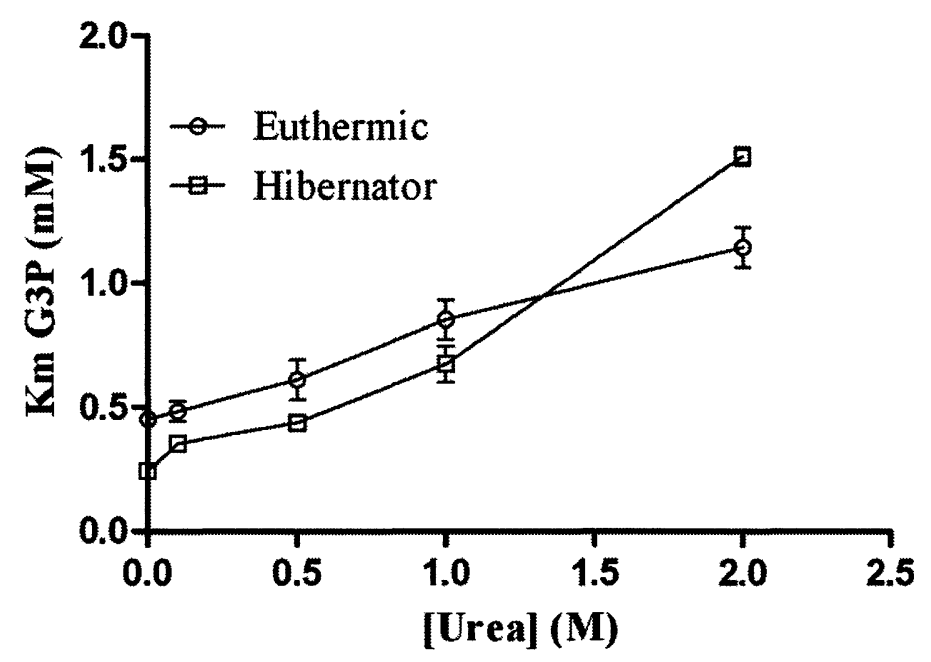

B

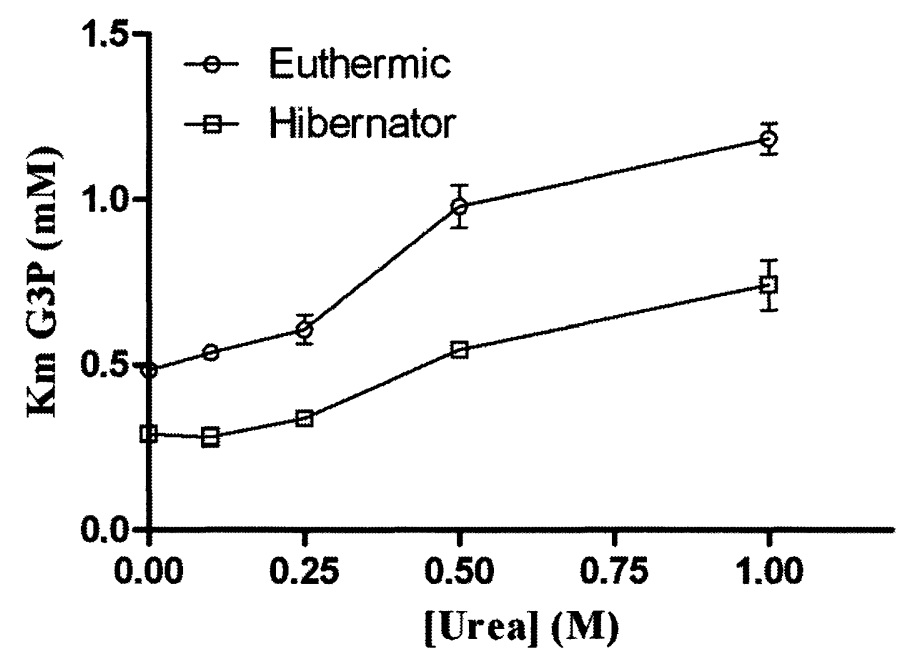

Figure 3.19: Urea effects on $\mathrm{K}_{\mathrm{m}} \mathrm{G} 3 \mathrm{P}$ of A) liver and B) muscle G3PDH from euthermic and hibernating S. richardsonii. Assays were performed in Tris buffer adjusted to $\mathrm{pH} 8.5$ at $23^{\circ} \mathrm{C}$. Assay conditions for a $200 \mu \mathrm{L}$ well at $23^{\circ} \mathrm{C}$ in the G3P utilizing direction: 20 $\mathrm{mM}$ Tris, $3 \mathrm{mM} \mathrm{NAD}^{+}$, variable amounts of G3P, $10 \mu \mathrm{L}$ of $100 \mathrm{X}$ diluted crude supernatant and 0-2 M urea. Data are means $\pm \mathrm{SEM}, \mathrm{N}=3$. 
$\mathbf{A}$

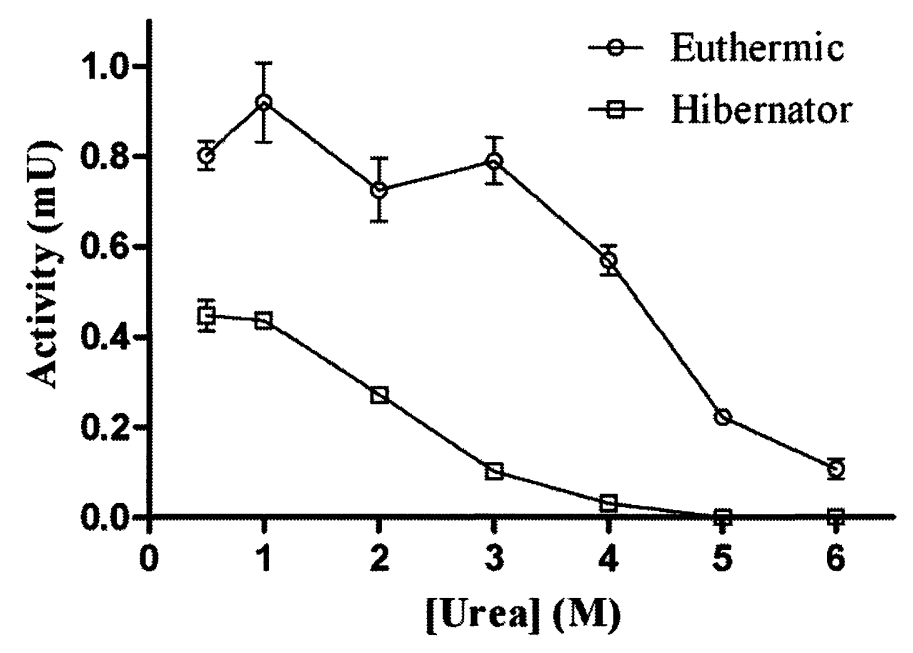

B

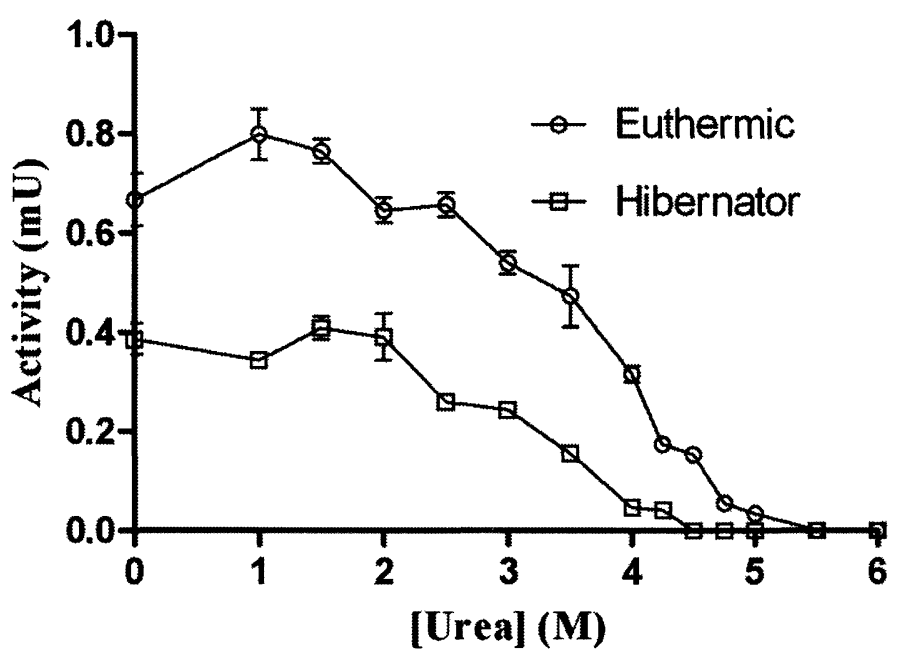

Figure 3.20: Effect of incubation with different concentrations of urea on A) liver and B) muscle G3PDH maximal activity from euthermic and hibernating $S$. richardsonii: Aliquots of enzyme were incubated for 90 minutes at different urea concentrations (0-6 M) followed by assay in the G3P utilizing direction for activity. In both tissues, calculated $\mathrm{I}_{50}$ values show that the hibernator form is more susceptible to urea denaturation. Data are means $\pm \mathrm{SEM}, \mathrm{N}=3$. 
Denaturant Effects: Urea Incubations and I50:

$\mathbf{A}$

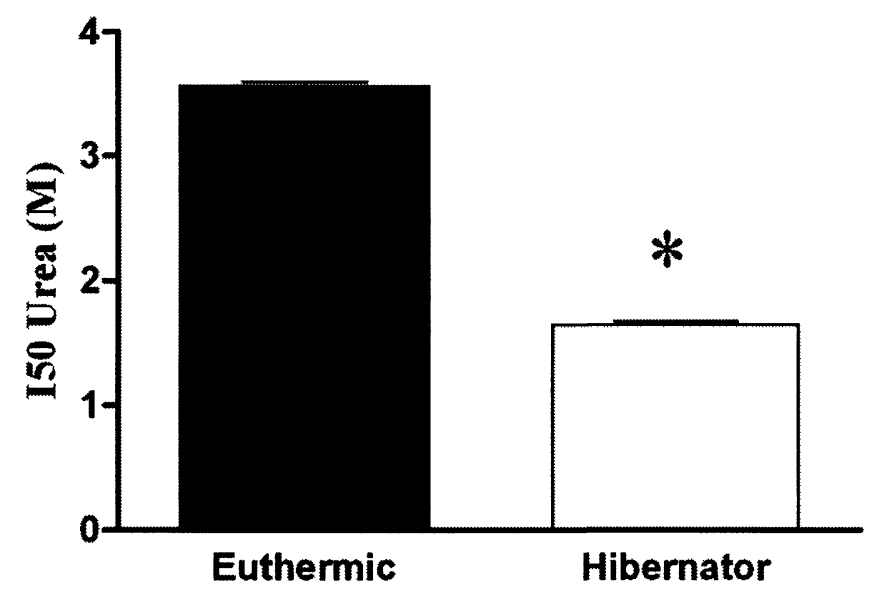

B

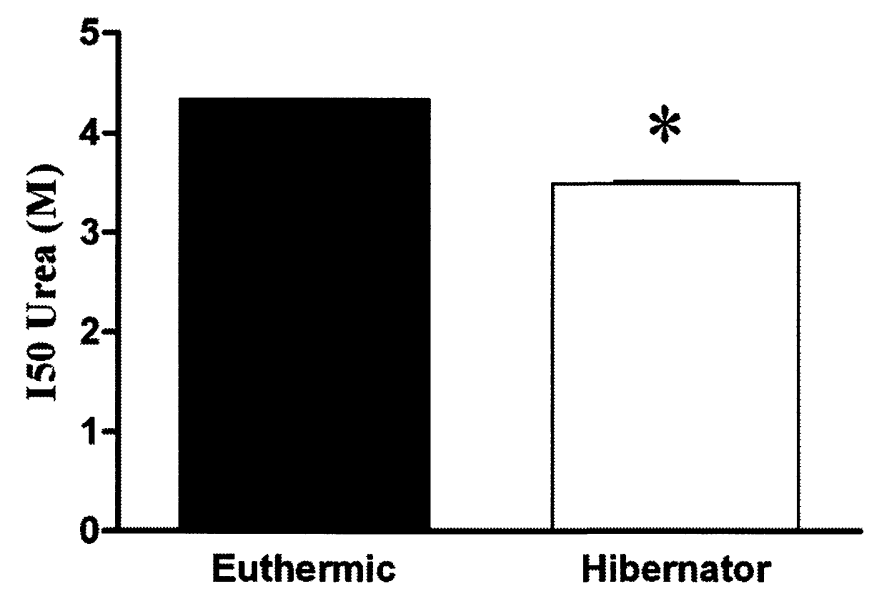

Figure 3.21: $I_{50}$ values for urea inhibition of A) liver and B) muscle G3PDH from euthermic and hibernating $S$. richardsonii. Enzyme was incubated for 90 minutes at different urea concentrations ( $0-6 \mathrm{M})$ followed by assay of activity in the G3P utilizing direction. There is a significant difference in $\mathrm{I}_{50}$ values for liver $(\mathrm{p}<0.0001)$ and muscle $(\mathrm{p}<0.0001)$ showing that the hibernator form more susceptible to urea denaturation in both tissues. Data are means $\pm \mathrm{SEM}, \mathrm{N}=3$. 


\section{Discussion}

It was postulated that since G3PDH is an important link between triglyceride catabolism and carbohydrate metabolism in mammals and since hibernators rely almost exclusively on lipid catabolism during torpor that this enzyme should be regulated during torpor and that stable modifications to G3PDH could be made by a posttranslational modification (PTM). Since a very common PTM affecting metabolic enzymes is reversible protein phosphorylation, an investigation of possible differential phosphorylation of Spermophilus richardsonii G3PDH between euthermic and hibernating states was conducted with accompanying kinetic analysis to investigate changes in enzyme properties between the two states

\section{pH Optima}

The $\mathrm{pH}$ optima of both liver and muscle G3PDH in the G3P-utilizing direction were $\sim 10$ which is quite basic (Fig 3.2). This provides a lead on the possible pH regulation of this enzyme. The $\mathrm{pH}$ in mammalian cells is normally close to neutral but in most tissues becomes relatively more acidic during torpor (Hochachka and Somero, 1984) due to a combination of effects of respiratory acidosis caused by apnoic breathing patterns and the effect of low $\mathrm{Tb}$ on intracellular buffer $\mathrm{pH}(\mathrm{pH}$ rises as temperature decreases). This is reversed rapidly when animals arouse. Hence, a change in the $\mathrm{pH}$ environment of cells could act to lower the G3P-utilizing activity of G3PDH during torpor and oppositely to accelerate the conversion of G3P to DHAP during arousal from torpor. In the DHAP-utilizing direction, the $\mathrm{pH}$ optimum was at a neutral value close to physiological pH (Fig 3.3), but the optimum was very sharp (approximately pH 6.8) so 
the enzyme could be distinctly affected by changing cellular $\mathrm{pH}$, making $\mathrm{pH}$ a possible regulator in this direction.

\section{Purification and phosphoprotein analysis}

Purification of G3PDH to homogeneity proved to be problematic despite trials with a number of different purification procedures. However, elution from a hydroxyapatite column provided a sharp peak (Fig 3.4,3.5) with high activity and a high fold purification factor (Table 3.1, 3. 2). This provided enough protein for electrophoresis which showed clear, strong immunoreactive bands at $\sim 37 \mathrm{kD}$ on SDS-PAGE (Fig 3.6). Western blotting showed no significant difference in total G3PDH protein content between euthermic and hibernating states for either tissue (Fig 3.6). By contrast, staining of a paired gel for phosphoprotein content showed significantly greater amounts of phosphate associated with G3PDH in both tissues from hibernating animals (Fig 3.7). Band intensity for hibernator G3PDH was 16 and $26 \%$ higher for liver and muscle respectively as compared with euthermic values. This demonstrates that entry into torpor results in enhanced phosphorylation of G3PDH.

\section{Kinetics}

Since triglycerides are the major fuel during torpor, the hibernating animal is faced with substantial amounts of glycerol produced when the fatty acids are cleaved off the triglyceride backbone. Glycerol is converted to G3P and then G3P can be catabolized during torpor and could represent an important fuel. G3P could be particularly important as a gluconeogenic substrate that can generate glucose fuel for tissues that cannot oxidize lipids. Although most organs of the hibernator are fueled by fatty acid oxidation and 
make use of the huge fat reserves in white adipose that are accumulated before the winter, those that need sugars (e.g. brain, retina, red blood cells, etc.) have to rely much smaller glycogen reserves as well as the conversion of some other metabolites to glucose via the gluconeogenesis (e.g. G3P, lactate, some amino acids). In the liver, glycogen stores are depleted during torpor and must be replenished. It has been confirmed that as much as $60 \%$ of G3P is converted to glycogen post-torpor (Galster and Morrison, 1970). Clearly this makes G3PDH, the link between fatty acid and glycolytic metabolism, a possible regulatory point for control by reversible protein phosphorylation. A similar situation could occur in muscle which also relies extensively on lipid oxidation during torpor although gluconeogenic capacity is low in muscle. Therefore, G3P generated in muscle may be used as a substrate for glycolysis and the TCA cycle. Kinetic changes in the enzyme, with the hibernator form having more affinity for substrate, will help confirm a regulatory role for this enzyme in a hibernating liver.

Hibernation-responsive changes in the properties of G3PDH could implicate active regulation of this enzyme, potentially enhancing its ability to process the G3P that is derived from triglyceride catabolism. Such changes might set up the enzyme to favor the G3P-utilizing direction during torpor or might aid function at cold temperatures. There was a clear difference in the $\mathrm{K}_{\mathrm{m}} \mathrm{G} 3 \mathrm{P}$ for liver G3PDH between euthermic and hibernating states (Fig 3.8 B) with the hibernator enzyme having a 47\% greater affinity for the substrate (Fig 3.8 A). However, there was no change in affinity for DHAP and $\mathrm{NAD}^{+}$of the liver enzyme (Fig 3.8 C, D). $\mathrm{V}_{\max }$ activity did not change between euthermic and hibernating states for the enzyme when assayed for G3P or NAD ${ }^{+}$at $23^{\circ} \mathrm{C}$ (Fig 3.8 A). However, there was a significant difference in DHAP $V_{\max }$ with the 
euthermic form having a $12 \%$ reduction in activity.

Muscle G3PDH also showed significant differences in kinetic properties between the euthermic and hibernating states (Fig 3.9 A). $\mathrm{K}_{\mathrm{m}} \mathrm{G} 3 \mathrm{P}$ decreased significantly for the hibernator form (Fig 3.9 B), representing a $40 \%$ increase in affinity for G3P. $\mathrm{K}_{\mathrm{m}} \mathrm{NAD}^{+}$ also decreased significantly (Fig $3.9 \mathrm{D}$ ), resulting in a $66 \%$ increase in affinity for $\mathrm{NAD}^{+}$. DHAP $\mathrm{V}_{\max }$ of the hibernator form was also reduced by $41 \%$ for the G3P-utilizing direction, as compared with the euthermic enzyme (Fig 3.9 A). This difference in $V_{\max }$ was also mirrored in the DHAP-utilizing direction where maximal activity of hibernator G3PDH was only about one-third of the value for the euthermic form. However, opposite of the pattern seen in the G3P-utilizing direction, enzyme affinity for DHAP was lower for the hibernator form (Fig 3.9 C) compared with the euthermic enzyme $\left(\mathrm{K}_{\mathrm{m}}\right.$ was $20 \%$ higher). This reduced affinity by the hibernator form for DHAP coupled with the increase in G3P and NAD ${ }^{+}$affinity strongly indicate that the G3P-utilizing direction is favoured in the hibernating state. This would support the role of the enzyme in catabolizing G3P that is produced during triglyceride catabolism during torpor.

\section{Incubations stimulating protein kinases and phosphatases on G3PDH}

In order to assess whether or not reversible protein phosphorylation is responsible for the changes in kinetic patterns of G3PDH between euthermic and hibernating states, the enzyme was subjected to treatments with protein kinases (stimulation of endogenous kinases + added PKA) or protein phosphatases (stimulation of endogenous phosphatases + added alkaline phosphatase) followed by a re-evaluation of the kinetics. Kinase

stimulation significantly lowered the $\mathrm{K}_{\mathrm{m}} \mathrm{G} 3 \mathrm{P}$ of euthermic $\mathrm{G} 3 \mathrm{PDH}$ from liver to a value 
similar to the $\mathrm{K}_{\mathrm{m}}$ of the hibernator form (Fig 3.10). However, kinase treatment did not affect the hibernator form of the enzyme. Combined with the information from phosphoprotein staining that showed that the hibernator form was the more phosphorylated entity, these data indicate that the transition from euthermia to torpor involves phosphorylation of G3PDH. Upon phosphorylation, the euthermic form adopts a new conformation that reduces its $\mathrm{G} 3 \mathrm{P} \mathrm{K}_{\mathrm{m}}$. By contrast, phosphatase treatment did not affect the euthermic enzyme but significantly increased the $K_{m}$ G3P of the hibernator enzyme, again supporting the conclusion that hibernator G3PDH is the high phosphate form. Comparable responses to kinase and phosphatase treatments occurred in muscle, again indicating that the euthermic and hibernator forms are the low and high phosphate forms, respectively. One difference in the muscle was the very strong effect of phosphatase treatment on euthermic G3PDH, effectively doubling the $\mathrm{Km}$ as compared with the control situation (Fig 3.11). This can be interpreted as indicating the euthermic G3PDH in muscle is in an intermediate state of phosphorylation that is susceptible to both kinase and phosphatase action. Euthermic G3PDH may have been partially phosphorylated in vivo by one type of kinase but the incubation conditions further stimulated the action of one or more additional kinases on G3PDH. Upon phosphatase treatment, however, the enzyme loses all of its covalently bound phosphate, resulting in an increase in $\mathrm{K}_{\mathrm{m}}$ of both the hibernator and euthermic enzymes to values about 2-fold higher than the corresponding controls.

\section{Arrhenius Plots and Activation Energy}

The activation energy of a reaction is the energy barrier that has to be overcome in order for the reaction to take place. In enzymatic reactions it is known as the Gibbs 
free energy. Enzymes in their working state are in their lowest energy form. Any modification to the enzyme will alter the energy state of the enzymatic system by increasing the overall energy of the system. An increase in the energy of the system translates to a decrease in the activation energy (Voet and Voet, 2004). Therefore, any PTM to an enzyme should affect the activation energy. Again, the role of $\mathrm{pH}$ over a temperature range could affect the enzyme activity. Imidazole (adjusted to $\mathrm{pH} 7.4$ at $23^{\circ} \mathrm{C}$ ) and phosphate (adjusted to $\mathrm{pH} 8.5$ at $23^{\circ} \mathrm{C}$ ) were the two buffer systems chosen for studies of temperature effects on activity since the change in $\mathrm{pH}$ with temperature of imidazole mimics intracellular conditions (where the buffering is mainly due to imidazolium groups on histidine residues), whereas phosphate shows a very minor $\mathrm{pH}$ change with temperature. The results showed that in both buffer systems G3PDH from muscle behaved similarly with the hibernator enzyme, the more phosphorylated form, showing significantly lower activation energy (Fig 3.14 B). In both buffer systems, the Arrhenius plots for muscle were also linear over the full temperature range tested with no breaks seen in the plots (Fig 3.13). However, for the liver enzyme there is a clear break in the linear plot for the hibernator in both buffer systems (Fig 3.12). Such breaks typically indicate a temperature-induced conformational change in protein structure that can alter enzyme properties; such breaks have been seen for other hibernator enzymes (Mehrani and Storey, 1997). As seen in muscle, there is a significant difference in $\mathrm{E}_{\mathrm{a}}$ between euthermic and hibernator conditions (upper and lower). This difference is enhanced at temperatures lower than $15^{\circ} \mathrm{C}$ in both buffer systems (Fig 3.14A). This suggests that the PTM stabilizes the dimer and this suggests that this enzyme is adapted for function at lower temperatures, especially in the liver. This makes intuitive sense since the liver is 
responsible for gluconeogenesis and thus the G3P buildup during hibernation can be shunted into this anabolic pathway during torpor, a scenario that would not be as important in muscle.

\section{Km vs Temperature}

The studies described above compared euthermic and hibernator enzymes at $23^{\circ} \mathrm{C}$ but when hibernating in nature, body temperature will track ambient temperature and often falls to near $0^{\circ} \mathrm{C}$. Enzymes that are considered to be crucial during hibernation are ones that do have adaptations to low temperature and should be able to function at or around $5^{\circ} \mathrm{C}$ (Somero and Hochachka, 1976). Therefore, it was also important to discover how ground squirrel G3PDH behaved at $5^{\circ} \mathrm{C}$, particularly with respect to the effects of post-translational modification. There are several factors that are involved here that must be taken into consideration. First, $\mathrm{pH}$ changes with temperature with the $\mathrm{pH}$ going up as the temperature goes down. Therefore, the choice of buffer is critical for analyzing enzymes at low temperature. Second, as indicated by the $\mathrm{pH}$ optimum curves, G3PDH activity is high at $\mathrm{pH}$ of 8.5 and could be the only $\mathrm{pH}$ at which the activity could be easily monitored as at low temperature. However, by mimicking the in vivo physiological $\mathrm{pH}$ conditions, studies might give a better idea of how the enzyme is functioning in hibernator cells at high versus low temperatures. Therefore, $K_{m}$ G3P vs temperature curves were done in both Tris buffer (adjusted to $\mathrm{pH} 8.5$ at $23^{\circ} \mathrm{C}$ ) and in imidazole (adjusted to $\mathrm{pH} 7.4$ at $23^{\circ} \mathrm{C}$ ); both buffers were allowed to fluctuate as assay temperature changed. Over the $20^{\circ} \mathrm{C}$ range tested, the enzyme from both tissues and in both buffers retained the lower $\mathrm{K}_{\mathrm{m}}$ value for hibernator G3PDH in comparison with the euthermic form (Fig 3.15, 3.16). The hibernator enzyme also showed very little change in $K_{m} G 3 P$ 
over this temperature range whereas $\mathrm{K}_{\mathrm{m}}$ values for euthermic G3PDH were strongly reduced by decreasing temperature. Therefore, one effect of the enhanced phosphorylation of G3PDH during torpor is that the enzyme maintains a low and quite stable $\mathrm{K}_{\mathrm{m}} \mathrm{G} 3 \mathrm{P}$ over a wide range of temperature. This would be important for enzyme function in vivo during torpor since lipid oxidation with G3P production occurs throughout the hibernating season during which $\mathrm{T}_{\mathrm{b}}$ will vary depending on ambient temperature of hibernator's burrow. The low $\mathrm{K}_{\mathrm{m}}$ phosphorylated hibernator form will also be more effective in metabolizing G3P as the animal warms up during each arousal period. Hence, an important effect of phosphorylation of G3PDH in both liver and muscle seems to be to create a low $\mathrm{K}_{\mathrm{m}}$ enzyme whose substrate affinity is also relatively temperature independent.

\section{Denaturant Effects:}

Given that global transcriptional and translational suppression occurs during torpor, the capacity for turnover of cellular proteins is much reduced and instead the emphasis appears to shift to long term preservation of cellular macromolecules.

Mechanisms that contribute to this include elevated levels of antioxidants and chaperone proteins in hypometabolic states (Storey, 1997). Individual enzymes might also be modified to have greater structural stability and/or functional half-life during hibernation. This might be another effect of PTM on G3PDH. To test this idea, the responses of the euthermic and hibernating forms of ground squirrel G3PDH were analyzed with respect to increasing concentrations of salt $(\mathrm{KCl})$ and denaturants (urea, $\mathrm{GHCl}$ ). Urea effects may also have physiological consequences for the hibernator because urea builds up as a metabolic end product of protein catabolism during torpor (Passmore et al., 2005). 
Overall, ground squirrel G3PDH showed no marked difference between euthermic and hibernating states in the effect of rising concentrations of $\mathrm{KCl}$ (Fig 3.17), $\mathrm{GHCl}$ (Fig 3.18) or urea (Fig 3.19) on $\mathrm{K}_{\mathrm{m}}$ G3P values. $\mathrm{K}_{\mathrm{m}}$ values were unaffected up to $0.25 \mathrm{M} \mathrm{KCl}$ or urea and to about $0.1 \mathrm{M} \mathrm{GHCl}$. So it appears that phosphorylation does not differentially alter the enzyme in terms of its susceptibility to salt or denaturant effect on $\mathrm{K}_{\mathrm{m}}$ values. However, when the enzyme was incubated in high urea for $90 \mathrm{~min}$, the two enzyme forms did show significant differences in suppression of activity by urea. $\mathrm{I}_{50}$ values were significantly lower for the phosphorylated hibernator form of the enzyme than the euthermic form for both liver and muscle G3PDH (Fig 3.20, 3.21), liver being particularly strongly affected. Hence, the hibernator form proved to be more susceptible to urea denaturation. This indicates that there is a difference in structural stability between the high and low phosphate forms of the enzyme. It seems counterintuitive that the enzyme in the hibernating animal would be less stable to elevated urea concentration. However, comparing the urea $I_{50}$ value to the ability of the enzyme to function in urea, it is clear that the urea $\mathrm{I}_{50}$ values that vary from 1.5 to $4 \mathrm{M}$ are very much higher than any possible in vivo value. Instead, what these data may indicate is that the hibernator enzyme is more flexible in structure. It unfolds and is denatured more easily by urea but greater flexibility of structure is an advantage for an enzyme that must function over a wide temperature range and especially at low temperatures (Hochachka and Somero, 1984). The concentration that suppresses activity is greater that $1 \mathrm{M}$, closer to $3.5 \mathrm{M}$. A decrease in urea $\mathrm{I}_{50}$ in the hibernating form is still well above the denaturing effects of urea on kinetics. This trades off the enhancement of kinetics by PTM over the possible stability decrease made by the same PTM. 


\section{Conclusion}

G3PDH shows increased phosphate content, differential kinetics with the majority of $\mathrm{K}_{\mathrm{m}}$ values significantly reduced and activation energies significantly reduced in the hibernator form in both tissues. Increased phosphorylation altered kinetics of the euthermic form to more closely resemble hibernator values and vice versa, and hibernator forms retained lower G3P $K_{m}$ at lower temperatures. This data suggests that G3PDH is regulated by reversible protein phosphorylation in liver and muscle of Richardson's ground squirrels. 


\section{Chapter 4}

\section{Evaluation of LDH for}

\section{Reversible Phosphorylation}




\section{Introduction:}

Lactate dehydrogenase (E.C. 1.1.1.27) is a reversible $\mathrm{NAD}(\mathrm{H})$ dependant heterotetramer. As the final enzyme in anaerobic glycolysis, it utilizes NADH produced at the glyceraldehyde-3-P dehydrogenase step and regenerates cytosolic NAD ${ }^{+}$(Voet and Voet, 2002). The mechanism is an ordered bi-bi reaction (Chiou et al., 1990) in which the oxidative direction (in terms of $\mathrm{NADH}$ ) uses pyruvate and $\mathrm{NADH}$ as substrates yielding lactic acid and $\mathrm{NAD}^{+}$, which are also the substrates for the reverse reduction direction. There are 2 main isoforms of the enzyme. In the liver and especially active muscle, the M4 isoform occurs which favors the formation of lactic acid to regenerate the limited cytosolic pool of $\mathrm{NAD}^{+}$for further anaerobic metabolism. In the heart, the $\mathrm{H} 4$ isoform favours the reverse reaction and aids the catabolism of lactate as an aerobic fuel (Moon 1978). The M4 form allows active muscle to rapidly produce lactic acid under conditions of intense contraction; much of this lactate can be exported in the blood and picked up by heart where the $\mathrm{H} 4$ isoform favours the reconversion of lactate to pyruvate that is then shunted into aerobic metabolism for ATP production. There have been reports of other isoforms as well as a third subunit in selective tissues in some vertebrates (Goldberg, 1965). 

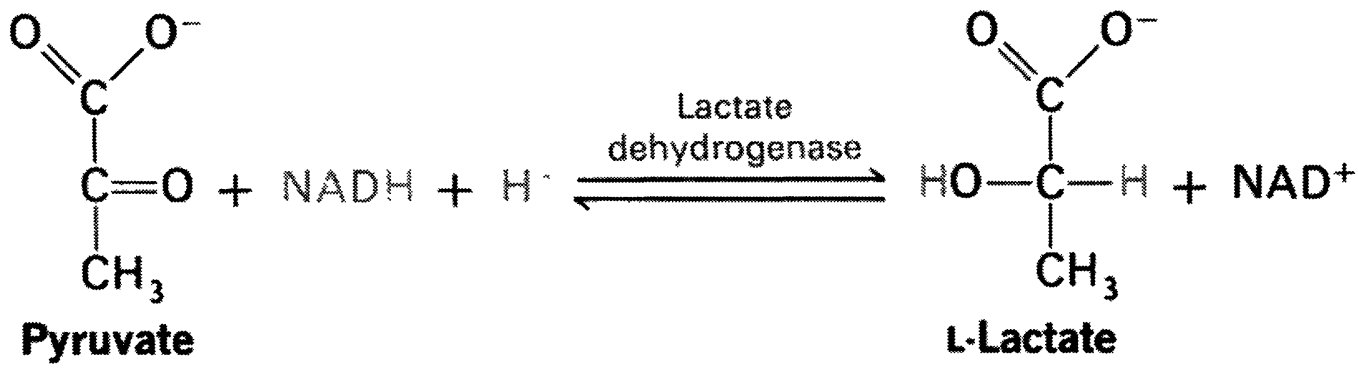

Figure 4.1: Overall reaction of the reversible $\mathrm{NAD}^{+}$dependant lactate dehydrogenase (E.C. 1.1.1.27). In the oxidation direction, pyruvate is converted to lactic acid with the generation of NAD+ with the reduction direction being the reverse (Berg et al., 2002).

New work has uncovered a mitochondrial isoform of $\mathrm{LDH}$ that shunts pyruvate into further catabolic reactions (de Bari et al., 2004). This could have implications for hibernation since gluconeogenesis is upregulated in hibernator liver. A pyruvate pool seems a dead end in hibernation as pyruvate dehydrogenase (PDH) is strongly suppressed during torpor (Storey, 1997); however, there seems to be some interaction with pyruvate and other citric acid cycle metabolite shuttle systems within the matrix of the mitochondria. Pyruvate that is generated from lactate in the mitochondrial matrix could be utilized by pyruvate carboxylase generating oxaloacetate from pyruvate (Panchal et al., 2001). The oxaloacetate formed by pyruvate carboxylase is then converted to phosphoenolpyruvate (PEP) by the enzyme PEP carboxykinase and PEP can then enter the gluconeogenic pathway (essentially a reversal of most enzymes of glycolysis).

LDH has been extensively analyzed in many systems for decades. LDH is a high activity, equilibrium enzyme and so very little consideration has been given to whether it 
might be subject to regulation by posttranslational modification such as by RPP. However, research on hibernating bats noted some activity changes in the pyruvate utilizing direction that suggest that a possible regulatory mechanism is at work on LDH during torpor and especially during the early stages of arousal (Moon, 1978). Regulation by temperature and by subunit ratios were suggested in that study but RPP could also play a role in modifying kinetics and stability.

\section{Hypothesis}

LDH is differentially regulated between euthermic and torpid states, at least in part, by a stable posttranslational modification of the enzyme.

This chapter studies the euthermic and hibernator forms of LDH from ground squirrel skeletal muscle analyzing kinetic and stability parameters and investigating differential phosphorylation of the enzyme as a means of altering/optimizing enzyme function during torpor. 


\section{Results}

\section{pH Optimum}

After establishing a working assay, $\mathrm{pH}$ curves were generated to establish optimal $\mathrm{pH}$ conditions. In the LA utilizing direction, the optimum $\mathrm{pH}$ for highest activity was 10 for both the liver and muscle enzyme from euthermic and hibernating animals (Fig. 4.2). In the pyruvate utilizing direction, the optimum $\mathrm{pH}$ for highest activity was 7 for both euthermic and hibernator LDH from both tissues (Fig. 4.3).

\section{Partial purification}

Using a cation exchange (CM) column as described in Materials and Methods section, $1 \mathrm{ml}$ of crude extract was placed on a $5 \mathrm{~cm}$ column of CM equilibrated in $20 \mathrm{mM}$ imidazole $\mathrm{pH}$ 7.0. After washing to remove unbound protein, $\mathrm{LDH}$ was eluted with a gradient of $0-2 \mathrm{M} \mathrm{KCl}$. LDH eluted at $\sim 0.6 \mathrm{M} \mathrm{KCl}$ for both liver and muscle forms from euthermic and hibernating animals (Fig. 4.4, 4.5). There was a 9.24\% and $2.34 \%$ recovery for liver LDH from euthermic and hibernator tissue, respectively (Table 4.1); comparable numbers were $2.92 \%$ and $2.25 \%$ recovery for muscle LDH (Table 4.2 ). Fold purification values were 196 and 284 fold purification for euthermic and hibernator liver LDH, respectively, and 10.8 and 29.2 fold purification for euthermic and hibernator muscle LDH, respectively. The specific activity of the crude liver euthermic form was $0.851 \mathrm{U} / \mathrm{mg}$ and the hibernator form was $0.550 \mathrm{U} / \mathrm{mg}$; after the CM purification, these values rose to 167 and $156 \mathrm{U} / \mathrm{mg}$, respectively. The specific activity of the muscle euthermic form was $2.85 \mathrm{U} / \mathrm{mg}$ and the hibernator form was $5.31 \mathrm{U} / \mathrm{mg}$; purification raised these values to 30.9 and $155 \mathrm{U} / \mathrm{mg}$, respectively. 


\section{Western Blotting}

After SDS-PAGE and immunoblotting with antibodies against mammalian LDH, strong bands of crossreacting protein were seen at $\sim 35 \mathrm{kD}$ for both liver and muscle extracts (Fig 4.6). This subunit molecular mass agrees with values for LDH from other species (http://www.brenda-enzymes.org/php/result flat.php4?ecno=1.1.1.27). No significant difference in LDH protein levels were seen between euthermic and hibernating states in either liver $(p=0.640, N=3)$ or muscle $(p=0.814, N=3)$.

\section{Pro Q Diamond phosphoprotein staining}

Other SDS-PAGE gels were run using the partially purified LDH (peak fraction from CM Sephadex) and then stained for phosphate content using the ProQ Diamond phosphoprotein stain. Bands were again detected at $\sim 35 \mathrm{kD}$ in both tissues. In both cases significant differences in the amount of bound phosphate were detected in liver $(\mathrm{p}<0.0001)$ and muscle $(\mathrm{p}=0.00124)$ between the two states with euthermic LDH showing the higher phosphate content. Phosphate content decreased by $74 \%$ in liver and $36 \%$ in muscle for the hibernator enzyme as compared with euthermia (Fig 4.7).

\section{Liver LDH kinetic properties}

Kinetic analysis of liver LDH in the LA utilizing direction showed no significant difference in the $K_{m}$ for LA $(p=0.619, N=2)($ Fig $4.8 B)$ or the $V_{\max }(p<0.0001, N=4)($ Fig 4.8 A) between euthermic and hibernating conditions. However, the $\mathrm{K}_{\mathrm{m}}$ for $\mathrm{NAD}^{+}$was significantly different between the two conditions $(p<0.0001, N=4)($ Fig $4.8 D)$; the value for hibernator LDH was 4-fold higher than the euthermic value (Fig 4.8 A) representing a major decrease in affinity for this substrate during torpor. In the pyruvate utilizing 
direction, there was no significant difference in the $K_{m}$ for pyruvate $(p=0.485, N=4)$ (Fig $4.8 \mathrm{C}$ ) between the two states but there was a significant difference in the $V_{\max }$ $(p=0.0012, N=4)\left(\right.$ Fig 4.8 A) that represented a 30\% decrease in $V_{\max }$ for the hibernator form.

\section{Muscle LDH Kinetic Properties}

Analysis of the kinetic properties of muscle LDH in the LA-utilizing direction showed no significant difference in the $K_{m}(p=0.803, N=4)($ Fig 4.9 B) but there was a significant difference in the $\mathrm{V}_{\max }(\mathrm{p}<0.0001, \mathrm{~N}=4)$ (Fig 4.9 A) between the euthermic and hibernator forms, representing a $44 \%$ decrease in $V_{\max }$ for the hibernator form. The

affinity for $\mathrm{NAD}^{+}$also changed significantly $(\mathrm{p}=0.0154, \mathrm{~N}=4)$ (Fig 4.9 D) representing a $37 \%$ decrease in the $\mathrm{K}_{\mathrm{m}}$ for the hibernator form. In the pyruvate utilizing direction, there was a significant difference in the $\mathrm{K}_{\mathrm{m}}(\mathrm{p}=0.0002, \mathrm{~N}=4)($ Fig $4.9 \mathrm{C})$ and the $\mathrm{V}_{\max }$ $(p=0.0003, N=4)($ Fig $4.9 C)$ between euthermic and hibernating states, representing a $43 \%$ and $54 \%$ increase in $\mathrm{K}_{\mathrm{m}}$ and $\mathrm{V}_{\max }$ respectively for the hibernator form.

\section{Incubations of Liver LDH to Stimulate Protein Kinases or Protein Phosphatases}

In vitro incubations were used to stimulation the activities of endogenous protein kinases or protein phosphatases and determine their effects on the kinetic properties of LDH. When protein kinases were stimulated, the $\mathrm{K}_{\mathrm{m}}$ of the euthermic form significantly increased $(p=0.0018, N=4)$ compared to the euthermic control representing, a $45 \%$ decrease in affinity for LA (Fig 4.10). There were similar results with the hibernator form; stimulation of protein kinases significantly increased the $K_{m}(p=0.0057, N=4)$ by $49 \%$. Upon stimulation of endogenous protein phosphatases, the $\mathrm{K}_{\mathrm{m}}$ was also 
significantly increased for both the euthermic $(p=0.0051, N=4)$ and hibernator $(p=0.0115$, $\mathrm{N}=4$ ) form of LDH representing a $51 \%$ and $47 \%$ decrease in affinity for LA, respectively.

\section{Incubations of Muscle LDH to stimulate Protein Kinases or Protein Phosphatases}

Stimulation of endogenous protein kinases and protein phosphatases also significantly changed the kinetics of muscle LDH compared to controls (Fig 4.11). When protein kinase action was stimulated, the $\mathrm{K}_{\mathrm{m}}$ for LA of the euthermic form increased significantly $(\mathrm{p}=0.0213, \mathrm{~N}=4)$ compared to the euthermic control representing a $46 \%$ decrease in affinity for LA. Hibernator LDH responded similarly, protein kinase stimulation significantly increasing the $\mathrm{K}_{\mathrm{m}}(\mathrm{p}=0.0502, \mathrm{~N}=4)$ by $33 \%$. Incubation under conditions that stimulated endogenous protein phosphatases also elevated $K_{m}$ LA of the euthermic enzyme $(p=0.0051, N=4)$ by $44 \%$. The hibernator enzyme showed the same trend ( $36 \%$ increase in $\mathrm{K}_{\mathrm{m}}$ ) but the data were not significantly different $(\mathrm{p}=0.0879, \mathrm{~N}=4)$.

The effect of stimulating endogenous protein kinases and protein phosphatases was also analyzed for the pyruvate-utilizing direction of muscle LDH (Fig 4.12). When protein kinases were stimulated, the $\mathrm{K}_{\mathrm{m}}$ of the hibernator form significantly decreased $(p=0.0043, N=4)$ compared to the hibernator control, representing a $39 \%$ increase in affinity for pyruvate. By contrast, upon stimulation of endogenous protein phosphatases, the $\mathrm{K}_{\mathrm{m}}$ of the euthermic form decreased significantly $(\mathrm{p}=0.0289, \mathrm{~N}=4)$, representing a $50 \%$ increase in affinity for pyruvate.

\section{Arrhenius Plots and Activation Energies}

Liver: A plot of $\log _{10} \mathrm{LDH}$ activity vs $1 /{ }^{\circ} \mathrm{K} \times 10^{-3}$ yielded a linear plot (Fig 4.13) with 1 break for both euthermic and hibernator forms when assessed under optimal assay 
conditions in phosphate $\mathrm{pH} 9.5$ and 1 break for the hibernator form in imidazole $\mathrm{pH} 7.4$. Breaks in the plots occurred at approximately $13^{\circ} \mathrm{C}$ for the phosphate system (Fig $4.13 \mathrm{~A}$ ) with a significant difference in $\mathrm{E}_{\mathrm{a}}$ between upper and lower temperatures for both the euthermic $(p<0.0001, N=4)$ and hibernator $(p=0.0001, N=4)$. There was also a significant difference in $E_{a}$ between euthermic and hibernator upper temperature $(p=0.0155, N=4)$ as well as euthermic and hibernator lower temperature $(\mathrm{p}<0.0001, \mathrm{~N}=4)$. In imidazole (Fig $4.13 \mathrm{~B})$, the break occurred at approximately $16^{\circ} \mathrm{C}$ for the euthermic form. There was a significant difference in $\mathrm{E}_{\mathrm{a}}$ between euthermic upper and lower temperatures $(\mathrm{p}<0.0001$, $\mathrm{N}=4$ ) as well as significant differences between euthermic upper temperature and hibernator $(\mathrm{p}<0.0001, \mathrm{~N}=4)$ and euthermic lower temperature and hibernator $(\mathrm{p}=0.0001$, $\mathrm{N}=4)$.

Muscle: Similar results were seen for muscle LDH. Plotting $\log _{10}$ LDH activity vs $1{ }^{\circ} \mathrm{K} \times 10^{-3}$ yielded a linear plot (Fig 4.14) with 1 break for the euthermic form in both phosphate $\mathrm{pH} 8.5$ (Fig $4.14 \mathrm{~A}$ ) and imidazole $\mathrm{pH} 7.4$ buffers. Breaks in the plots occurred at approximately $13^{\circ} \mathrm{C}$ for the imidazole system (Fig $4.14 \mathrm{~B}$ ) with a significant difference in $E_{a}$ between upper and lower temperatures for the euthermic form $(p<0.0001, N=4)$ as well as a significant difference between euthermic upper temperature and hibernator $(\mathrm{p}<0.0001, \mathrm{~N}=4)$ and between euthermic lower temperature and hibernator $(\mathrm{p}<0.0001$, $\mathrm{N}=4)$.

\section{Effect of Temperature Change on $K_{m} L A$}

Liver: The effects of changing assay temperature on the affinity of liver LDH for lactate is shown in Fig 4.17A. Temperature change had no significant effect on the $\mathrm{K}_{\mathrm{m}}$ 
lactate of the euthermic enzyme form over the range between 5 and $25^{\circ} \mathrm{C}(\mathrm{p}=0.657, \mathrm{~N}=4)$ (assays in imidazole buffer that was adjusted to $\mathrm{pH} 7.4$ at $23^{\circ} \mathrm{C}$ and then $\mathrm{pH}$ was allowed to change with temperature). The $\mathrm{K}_{\mathrm{m}}$ of the hibernator enzyme was also largely unchanged between 5 and $20^{\circ} \mathrm{C}$ but rose significantly, nearly doubling at $25^{\circ} \mathrm{C}$ $(\mathrm{p}=0.0009, \mathrm{~N}=4)$.

Muscle: Changing temperature had a marked effect on the kinetics of the $K_{m} L A$ of the muscle enzyme from both euthermic and hibernator conditions (assays in imidazole buffer adjusted to $\mathrm{pH} 7.4$ at $23^{\circ} \mathrm{C}$ ) (Fig $4.17 \mathrm{~B}$ ). Both forms showed a minimum $\mathrm{K}_{\mathrm{m}}$ at $10^{\circ} \mathrm{C}$. This was unchanged for the hibernator form assayed at $5^{\circ} \mathrm{C}$ but euthermic $\mathrm{LDH}$ showed an increase in $\mathrm{K}_{\mathrm{m}}$ at $5^{\circ} \mathrm{C}$. As temperature rose above $10^{\circ} \mathrm{C}$, the $\mathrm{K}_{\mathrm{m}}$ value for both euthermic and hibernator $\mathrm{LDH}$ increased progressively. $\mathrm{K}_{\mathrm{m}}$ values at $25^{\circ} \mathrm{C}$ were $48 \%$ and $44 \%$ higher than the minimum $\mathrm{K}_{\mathrm{m}}$ value at $10^{\circ} \mathrm{C}$ for euthermic $(p=0.0075, N=4)$ and hibernator $(p=0.0267, N=4) L D H$, respectively.

\section{Liver: Salt and Denaturant Effects on Kinetics}

The effects of $\mathrm{KCl}, \mathrm{GHCl}$ or urea on the $\mathrm{K}_{\mathrm{m}} \mathrm{LA}$ of liver $\mathrm{LDH}$ were tested. In all cases, as the concentration of additive increased, the $\mathrm{K}_{\mathrm{m}}$ increased. $\mathrm{KCl}$ had strong effects, affecting $\mathrm{K}_{\mathrm{m}}$ at concentrations as low as $0.1 \mathrm{M}$ and resulting in an approximate 3fold increase in $\mathrm{K}_{\mathrm{m}} \mathrm{LA}$ when [ $\mathrm{KCl}$ ] rose to $0.5 \mathrm{M}$ (Fig $4.18 \mathrm{~A}$ ). $\mathrm{GHCl}$ also strongly affected $\mathrm{K}_{\mathrm{m}}$ at $0.25 \mathrm{M}$, raising $\mathrm{K}_{\mathrm{m}}$ of the euthermic enzyme by about 2.5 fold and that of the hibernator form by 4-fold (Fig 4.19 A). Urea also affected $\mathrm{K}_{\mathrm{m}}$ LA but less so than the other two effectors. Indeed, at low levels $(0.1 \mathrm{M})$, the effect was actually to lower the $\mathrm{K}_{\mathrm{m}}$ of the euthermic enzyme slightly but values rose again by $0.25 \mathrm{M}$ and were significantly higher than the control $\mathrm{K}_{\mathrm{m}}$ when urea levels reached 0.5 M (Fig 4.20 A). 
The effect of pre-incubation of liver LDH with urea prior to assay was also tested. Urea had a denaturing effect that reduced the detectable activity as a function of increasing urea concentration. Euthermic and hibernator liver LDH responded differently to urea with significant differences in the calculated $\mathrm{I}_{50}$ urea values $(\mathrm{p}=0.001, \mathrm{~N}=3)$, showing that the hibernator form was more susceptible to urea denaturation (Fig 4.21 A, Fig 4.22A). Indeed, the $\mathrm{I}_{50}$ value was $0.71 \mathrm{M}$ for euthermic liver $\mathrm{LDH}$ and $23 \%$ lower at $0.55 \mathrm{M}$ for the hibernator form (Fig 4.8 A).

\section{Muscle: Salt and Denaturant Effects on Kinetics}

Effects of $\mathrm{KCl}, \mathrm{GHCl}$ and urea on the $\mathrm{K}_{\mathrm{m}} \mathrm{LA}$ of muscle LDH are shown in Fig. 4.18 B, 4.19 B and 4.20 B, respectively. Again, the $\mathrm{K}_{\mathrm{m}}$ value increased with increasing concentrations of these additives and again $\mathrm{KCl}$ and $\mathrm{GHCl}$ had stronger effects on kinetics at lower concentrations than did urea. $\mathrm{KCl}$ showed only minimal effects on $\mathrm{K}_{\mathrm{m}}$ up to $0.25 \mathrm{M}$ but at $0.5 \mathrm{M} \mathrm{KCl}$, the $\mathrm{K}_{\mathrm{m}}$ of the hibernator form was increased by $\sim 2$-fold and $\mathrm{K}_{\mathrm{m}}$ of the euthermic form rose by about $49 \% . \mathrm{K}_{\mathrm{m}}$ was unaffected in the presence of $0.1 \mathrm{M} \mathrm{GHCl}$ but increased by about 2-fold when $\mathrm{GHCl}$ was increased to $0.25 \mathrm{M}$. By contrast, urea had no effect on $\mathrm{K}_{\mathrm{m}} \mathrm{LA}$ up to $0.5 \mathrm{M}$ but in the presence of $1 \mathrm{M}$ urea, $\mathrm{K}_{\mathrm{m}}$ increased by 57 and $70 \%$ for the euthermic and hibernator enzyme, respectively.

The effect of pre-incubation with urea on subsequent activity was also tested for muscle LDH and, as for liver LDH, activity decreased as [urea] increased (Fig 4.21 B, Fig $4.22 \mathrm{~B})$. The effect of urea was greater on hibernator $\mathrm{LDH}$ so that $\mathrm{I}_{50}$ urea values were significantly different from euthermia $(\mathrm{p}=0.0077, \mathrm{~N}=3)$. $\mathrm{I}_{50}$ was $1.08 \mathrm{M}$ for euthermic muscle LDH and $0.88 \mathrm{M}$ for the hibernator form (Fig 4.9 A). 


\section{Interaction of Reversible Phosphorylation and Susceptibility to Urea Denaturation}

Liver: LDH from liver of euthermic and hibernating ground squirrels was incubated in vitro under conditions that stimulated the actions of endogenous kinases or phosphatases (ie. same incubation samples from above), and then urea stability of the enzyme was retested (Fig 4.23). After treatment with protein kinases, euthermic LDH showed no change in its $I_{50}$ value for urea but hibernator LDH was significantly affected $(p=0.0018, N=3)$, the $I_{50}$ urea increasing by $22 \%$ as compared to hibernator controls. The opposite response was seen for LDH treated with phosphatases. Euthermic LDH showed a significant decrease $(\mathrm{p}=0.0425, \mathrm{~N}=3)$ in $\mathrm{I}_{50}$ urea by $16 \%$ after phosphatase treatment, as compared to euthermic controls, whereas hibernator LDH response to urea was unchanged.

Muscle: Comparable tests were carried out with muscle LDH (Fig 4. 24).

Although the $I_{50}$ for urea was significantly different between the euthermic and hibernator control samples, neither kinase nor phosphatase treatments significantly changed the $\mathrm{I}_{50}$ for urea of euthermic $(\mathrm{p}=0.684, \mathrm{~N}=3)$ or hibernator $(\mathrm{p}=0.9348, \mathrm{~N}=3) \mathrm{LDH}$. 


\section{Results:}

pH Optima: LA Utilizing Direction:

$\mathbf{A}$

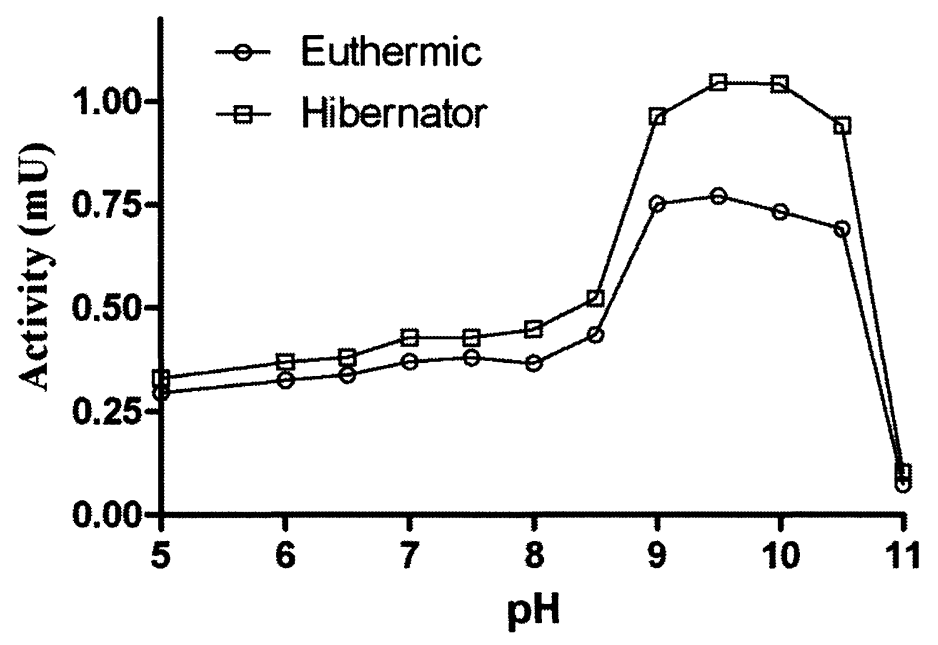

B

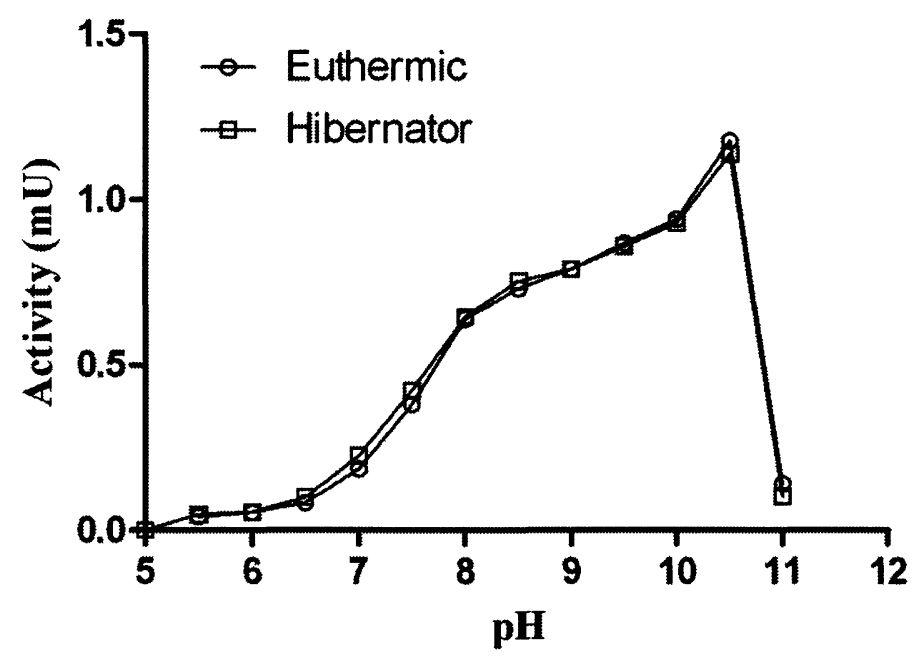

Figure 4.2: Effect of $\mathrm{pH}$ on $\mathrm{LDH}$ activity from A) liver and B) muscle of euthermic and hibernating Spermophilus richardsonii. Assay conditions for a $200 \mu \mathrm{l}$ well in the lactic acid utilizing direction: $20 \mathrm{mM}$ phosphate buffer, $10 \mu \mathrm{l}$ of crude supernatant (500X dilution), $3 \mathrm{mM} \mathrm{NAD}^{+}$and $12.5 \mathrm{mM}$ lactic acid. Phosphate buffer was used as the $\mathrm{pH}$ ranged from 5-11. Data are means $\pm \mathrm{SEM}, \mathrm{n}=1$ determinations. 


\section{pH Curves: Pyruvate Utilizing Direction:}

$\mathbf{A}$

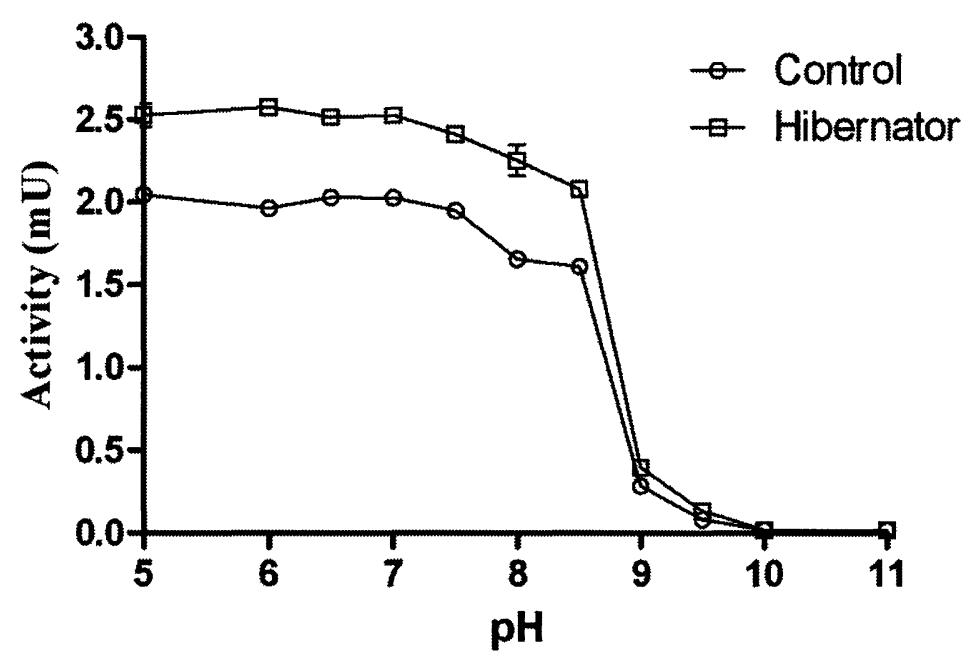

B

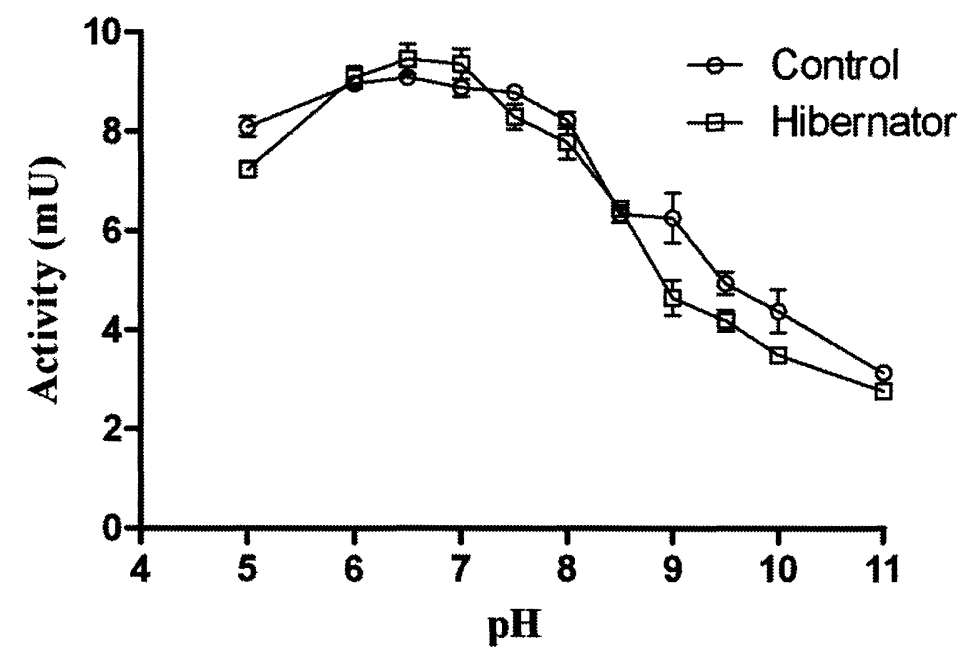

Figure 4.3: Effect of $\mathrm{pH}$ on LDH activity from A) liver and B) muscle of euthermic and hibernating S. richardsonii. Assay conditions for a $200 \mu 1$ well in the pyruvate utilizing direction: $20 \mathrm{mM}$ phosphate buffer, $10 \mu \mathrm{l}$ of crude supernatant (500X dilution), 0.263 $\mathrm{mM} \mathrm{NADH}$ and $0.125 \mathrm{mM}$ pyruvate. Phosphate buffer was used as the $\mathrm{pH}$ ranged from 5-11. Data are means \pm SEM, $n=3$ determinations. Where error bars are not shown, they are within the dimensions of the symbol. 


\section{Partial Purification: Liver}

Table 4.1: Partial purification of liver LDH from euthermic and hibernating $S$. richardsonii showing elution data from a CM- column.

\begin{tabular}{|c|c|c|c|c|c|}
\hline $\begin{array}{c}\text { Purification } \\
\text { Step }\end{array}$ & $\begin{array}{c}\text { Total } \\
\text { Protein } \\
(\mathrm{mg})\end{array}$ & $\begin{array}{c}\text { Total } \\
\text { Activity } \\
(\mathrm{U})\end{array}$ & Yield (\%) & $\begin{array}{c}\text { Fold } \\
\text { Purification }\end{array}$ & $\begin{array}{c}\text { Specific } \\
\text { Activity } \\
\text { (U/mg) }\end{array}$ \\
\hline $\begin{array}{c}\text { Crude } \\
\text { Euthermic }\end{array}$ & $\begin{array}{c}225 \pm \\
5.59\end{array}$ & $\begin{array}{c}191.5 \pm \\
9.25\end{array}$ & NA & NA & 0.851 \\
\hline $\begin{array}{c}\text { CM- } \\
\text { Euthermic }\end{array}$ & $\begin{array}{c}0.106 \pm \\
0.00208\end{array}$ & 17.7 & 9.24 & 196 & 167 \\
\hline $\begin{array}{c}\text { Crude } \\
\text { Hibernator }\end{array}$ & $331 \pm$ & $182 \pm$ & NA & NA & 0.550 \\
\hline $\begin{array}{c}\text { CM- } \\
\text { Hibernator }\end{array}$ & $\begin{array}{c}3.46 \\
0.0272 \pm\end{array}$ & 4.25 & 2.34 & 284 & 156 \\
\hline
\end{tabular}

A

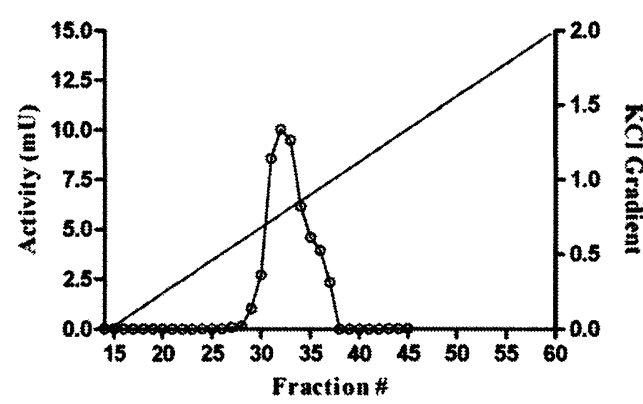

B

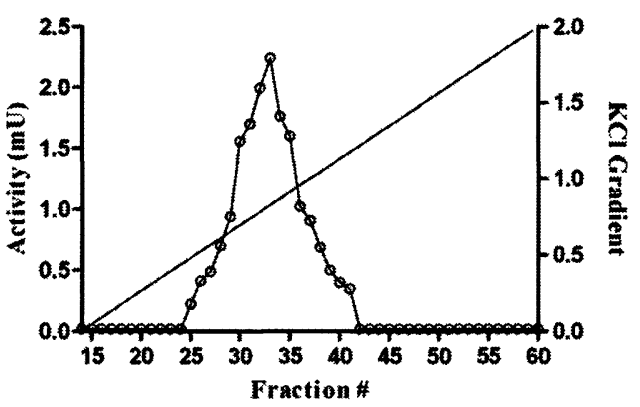

Figure 4.4: LDH elution profiles from a hydroxyapatite column. (A) euthermic liver, (B) hibernator liver. After the addition of $0.5 \mathrm{ml}$ of crude supernatant, the column was washed with $20 \mathrm{mM}$ imidazole $\mathrm{pH} 7$ (euthermic: fraction 0-13, hibernator: fraction 0-14) until no LDH activity was detected. A $2 \mathrm{M} \mathrm{KCl}$ gradient in the same buffer followed, starting at euthermic: fraction 14, hibernator: fraction 15 . Assay conditions for a $200 \mu 1$ well in the lactic acid utilizing direction: $20 \mathrm{mM}$ phosphate buffer $\mathrm{pH} 9.5$ at $23^{\circ} \mathrm{C}, 10 \mu \mathrm{l}$ of purified supernatant (500X dilution), $3 \mathrm{mM} \mathrm{NAD}^{+}$and $12.5 \mathrm{mM}$ lactic acid. 


\section{Partial Purification: Muscle}

Table 4.2: Purification table for muscle LDH from euthermic and hibernating $S$. richardsonii showing elution data from a CM- column.

\begin{tabular}{|c|c|c|c|c|c|}
\hline $\begin{array}{c}\text { Purification } \\
\text { Step }\end{array}$ & $\begin{array}{c}\text { Total } \\
\text { Protein } \\
(\mathrm{mg})\end{array}$ & $\begin{array}{c}\text { Total } \\
\text { Activity } \\
(\mathrm{U})\end{array}$ & Yield (\%) & $\begin{array}{c}\text { Fold } \\
\text { Purification }\end{array}$ & $\begin{array}{c}\text { Specific } \\
\text { Activity } \\
(\mathrm{U} / \mathrm{mg})\end{array}$ \\
\hline $\begin{array}{c}\text { Crude } \\
\text { Euthermic }\end{array}$ & $\begin{array}{c}155 \pm \\
16\end{array}$ & $\begin{array}{c}442 \pm \\
46.3\end{array}$ & NA & NA & 2.85 \\
\hline $\begin{array}{c}\text { CM- } \\
\text { Euthermic }\end{array}$ & $\begin{array}{c}0.417 \pm \\
0.154\end{array}$ & 12.9 & 2.92 & 10.8 & 30.9 \\
\hline & & & & & \\
\hline $\begin{array}{c}\text { Crude } \\
\text { Hibernator }\end{array}$ & $\begin{array}{c}181 \pm \\
12.8\end{array}$ & $\begin{array}{c}961 \pm \\
51.6\end{array}$ & NA & NA & 5.31 \\
\hline $\begin{array}{c}\text { CM- } \\
\text { Hibernator }\end{array}$ & $\begin{array}{c}0.139 \pm \\
0.0686\end{array}$ & 21.6 & 2.25 & 29.2 & 155 \\
\hline
\end{tabular}

A

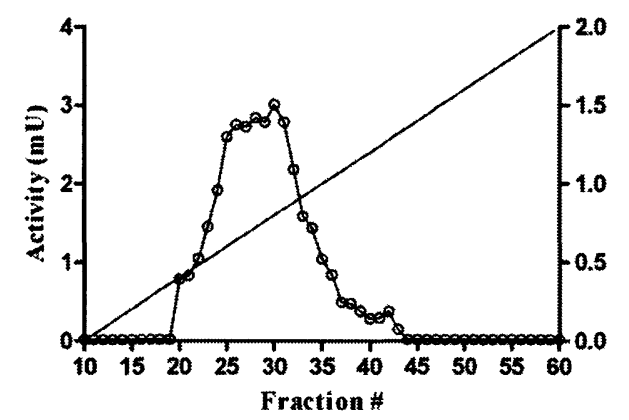

B

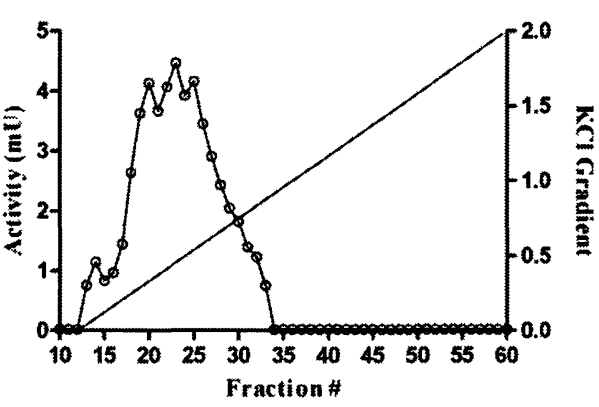

Figure 4.5: LDH elution profiles off a hydroxyapatite column. (A) euthermic muscle, (B) hibernator muscle. After the addition of $0.5 \mathrm{ml}$ of crude supernatant, the column was washed with $20 \mathrm{mM}$ imidazole $\mathrm{pH} 7$ (euthermic: fraction 0-9, hibernator: fraction 0-12) until no LDH activity was detected. A $2 \mathrm{M} \mathrm{KCl}$ gradient in the same buffer followed, starting at euthermic: fraction 10, hibernator: fraction 13. Assay conditions for a $200 \mu 1$ well in the lactic acid utilizing direction: $20 \mathrm{mM}$ phosphate buffer $\mathrm{pH} 9.5$ at $23^{\circ} \mathrm{C}, 10 \mu \mathrm{l}$ of purified supernatant (500X dilution), $3 \mathrm{mM} \mathrm{NAD}^{+}$and $12.5 \mathrm{mM}$ lactic acid. 


\section{Western Blots:}

A

Euthermic $\quad \sim 35 \mathrm{kD} \quad$ Hibernator
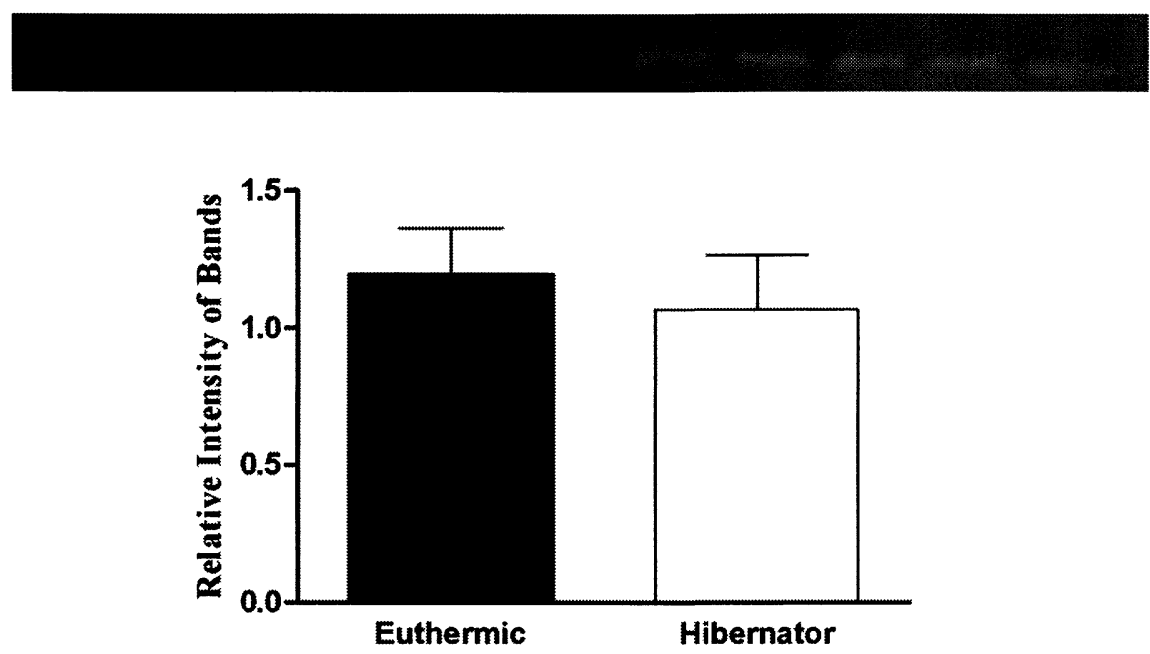

B

Euthermic $\quad \sim 35 \mathrm{kD} \quad$ Hibernator
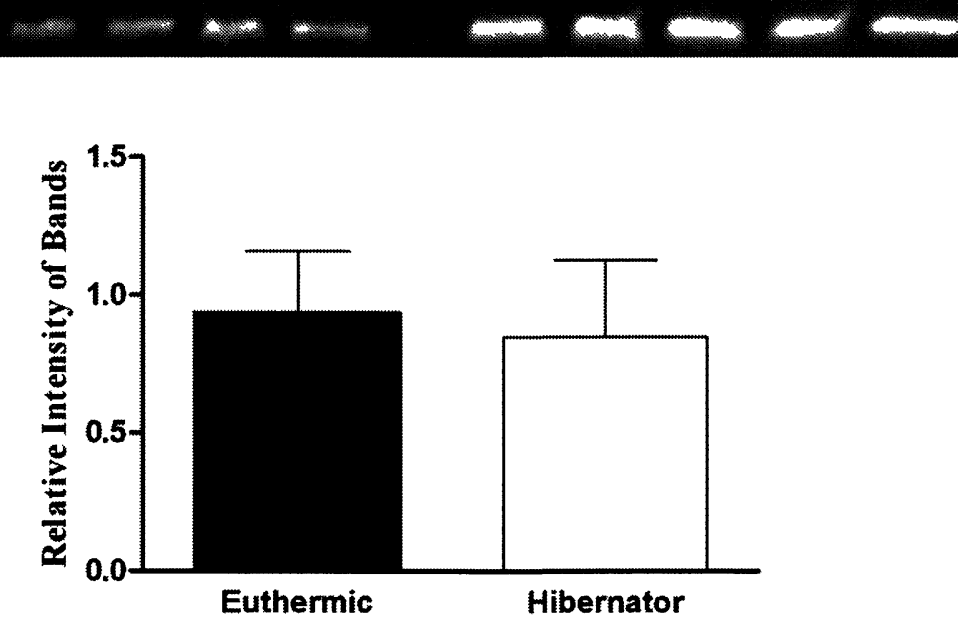

Figure 4.6: Western blotting assessing LDH protein levels in (A) liver and (B) muscle of euthermic versus hibernating $S$. richardsonii. There was no significant difference in LDH protein content between the two states in either liver $(p=0.6397)$ or muscle $(p=0.8138)$. Lanes were loaded with $10 \mu \mathrm{l}$ of $2.56 \mu \mathrm{g} / \mu \mathrm{l}$ crude blue supernatant. Data are means \pm $\mathrm{SEM}, \mathrm{N}=3$ biological replicates, $\mathrm{N}=5$ technical replicates per biological replicate. 


\section{Pro Q Diamond Phosphoprotein Staining:}

$\mathbf{A}$

$\sim 35 \mathrm{kD} \quad$ Euthermic

Hibernator

$\mathrm{LDH}$
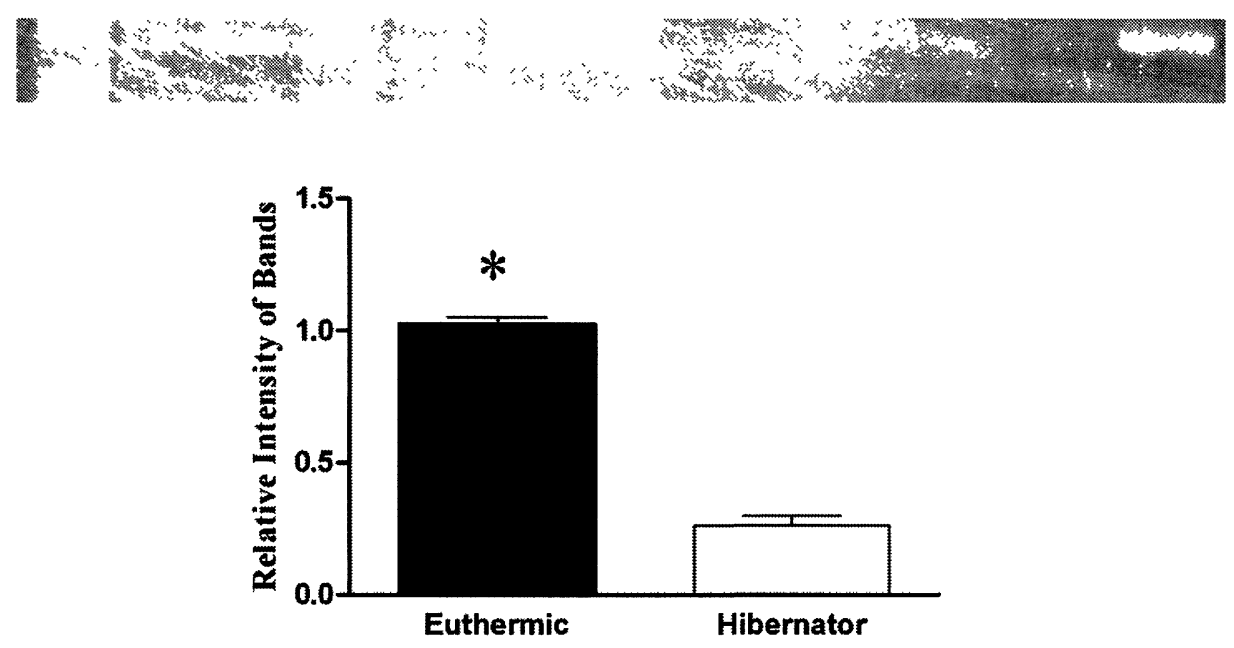

B

$\sim 35 \mathrm{kD} \quad$ Euthermic Hibernator $\quad$ LDH
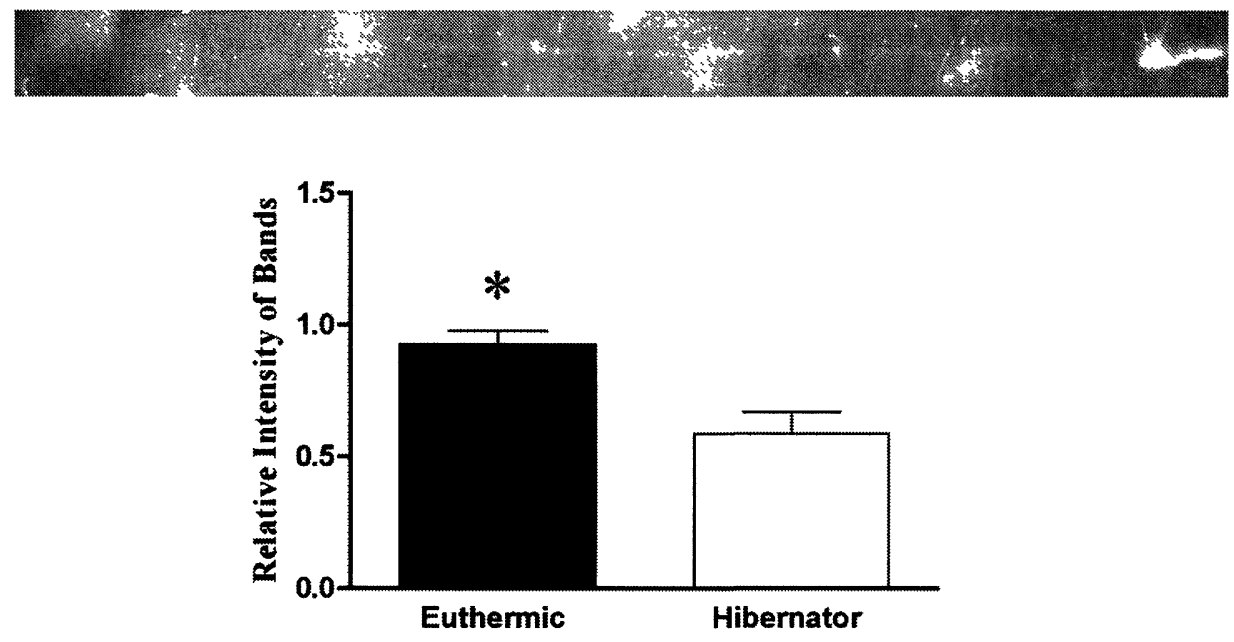

Figure 4.7: Relative amount of phosphorylated LDH as detected by ProQ Diamond staining in samples of partial purified enzyme from (A) liver and (B) muscle of euthermic and hibernating $S$. richardsonii. Comparison for correct $\mathrm{MW}$ was made to commercial rabbit $\mathrm{LDH}$. There is a significant difference in phosphorylation between the two states for liver $(\mathrm{p}<0.0001)$ and muscle $(\mathrm{p}=0.0124)$ with the hibernator being less phosphorylated in both cases. Lanes were loaded with $10 \mu \mathrm{l}$ of $6.7 \mathrm{ng} / \mu 1$ partially purified enzyme Data are means \pm SEM, $\mathrm{N}=5$. 
Kinetics: Liver

A

\begin{tabular}{|c|c|c|c|}
\hline Parameter & Euthermic & Hibernator & $\begin{array}{l}\text { Significant } \\
\text { Difference }\end{array}$ \\
\hline $\mathrm{V}_{\max }$ Pyruvate (U/gww) & $745 \pm 36.1$ & $525 \pm 12.8$ & Yes \\
\hline $\mathrm{K}_{\mathrm{m}}$ Pyruvate, $\mathbf{m M}$ & $0.0074 \pm 0.00113$ & $0.00636 \pm 0.00082$ & No \\
\hline$V_{\max }$ LA (U/gww) & $205 \pm 1.65$ & $685 \pm 15.3$ & Yes \\
\hline $\mathrm{K}_{\mathrm{m}} \mathrm{LA}, \mathrm{mM} \mathrm{23^{ \circ } \mathrm { C }}$ & $4.74 \pm 0.42$ & $5.05 \pm 0.415$ & No \\
\hline $\mathbf{K}_{\mathrm{m}} \mathbf{N A D}^{+}, \mathbf{m M}$ & $0.18 \pm 0.0058$ & $0.73 \pm 0.054$ & Yes \\
\hline $\mathrm{K}_{\mathrm{m}} \mathrm{LA}, \mathrm{mM} \mathrm{25^{ \circ } \mathrm { C }}$ & $3.71 \pm 0.26$ & $7.83 \pm 0.56$ & Yes \\
\hline $\mathrm{K}_{\mathrm{m}} \mathrm{LA}, \mathrm{mM} 5^{\circ} \mathrm{C}$ & $4.11 \pm 1.19$ & $4.13 \pm 0.22$ & No \\
\hline $\mathbf{E}_{\mathrm{a}}\left(\mathrm{kcal} \mathrm{\textrm {mol } ^ { - 1 } )}\right.$ & $6.34 \pm 0.31$ & $9.06 \pm 0.074$ & Yes \\
\hline$I_{50}$ Urea, $M$ & $0.71 \pm 0.022$ & $0.55 \pm 0.018$ & Yes \\
\hline
\end{tabular}

B

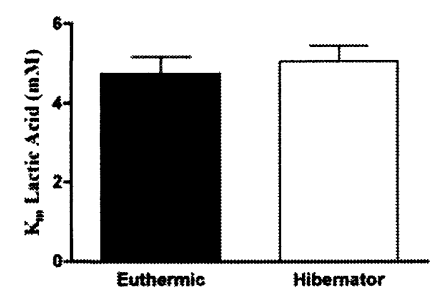

C

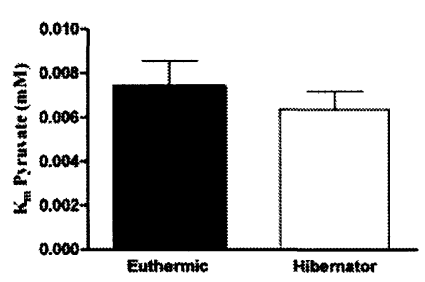

D

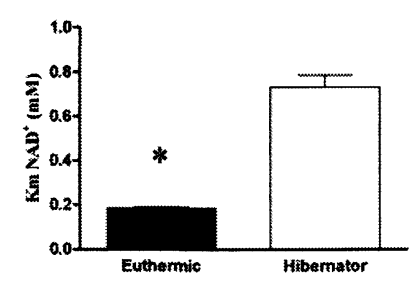

Figure 4.8: Kinetic parameters of liver LDH from euthermic and hibernating $S$. richardsonii showing A) kinetic values for several kinetic variables with significant differences listed. Specifically, there was no significant difference between euthermic and hibernator $\mathrm{LA} \mathrm{K}_{\mathrm{m}}(\mathrm{B}: \mathrm{p}=0.6187)$, and PYR $\mathrm{K}_{\mathrm{m}}(\mathrm{C}: \mathrm{p}=0.4847)$ but there was significant difference between euthermic and hibernator $\mathrm{NAD}^{+} \mathrm{K}_{\mathrm{m}}(\mathrm{D}: \mathrm{p}<0.0001)$. Data are means \pm $\mathrm{SEM}, \mathrm{N}=4$. 
Kinetics: Muscle

A

\begin{tabular}{|c|c|c|c|}
\hline Parameter & Euthermic & Hibernator & $\begin{array}{l}\text { Significant } \\
\text { Difference }\end{array}$ \\
\hline$V_{\max }$ Pyruvate (U/gww) & $1375 \pm 144$ & $2990 \pm 161$ & Yes \\
\hline$K_{\mathrm{m}}$ Pyruvate, $\mathrm{mM}$ & $0.039 \pm 0.0011$ & $0.069 \pm 0.0035$ & Yes \\
\hline$V_{\max } L A(U / g w w)$ & $1165 \pm 2.13$ & $650 \pm 8.35$ & Yes \\
\hline $\mathrm{K}_{\mathrm{m}} \mathrm{LA}, \mathrm{mM} 23^{\circ} \mathrm{C}$ & $5.71 \pm 0.83$ & $6.02 \pm 0.74$ & No \\
\hline $\mathbf{K}_{\mathrm{m}} \mathrm{NAD}^{+}, \mathbf{m M}$ & $1.23 \pm 0.12$ & $0.78 \pm 0.071$ & Yes \\
\hline $\mathrm{K}_{\mathrm{m}} \mathrm{LA}, \mathrm{mM} 25^{\circ} \mathrm{C}$ & $8.09 \pm 0.40$ & $6.33 \pm 0.63$ & No \\
\hline $\mathrm{K}_{\mathrm{m}} \mathrm{LA}, \mathrm{mM} 5^{\circ} \mathrm{C}$ & $5.46 \pm 0.53$ & $3.56 \pm 0.58$ & No \\
\hline $\mathrm{E}_{\mathrm{a}}\left(\mathrm{kcal} \mathrm{mol}^{-1}\right)$ & $4.89 \pm 0.10$ & $10.3 \pm 0.083$ & Yes \\
\hline $\mathbf{I}_{50}$ Urea, $\mathbf{M}$ & $1.08 \pm 0.028$ & $0.88 \pm 0.030$ & Yes \\
\hline
\end{tabular}

B

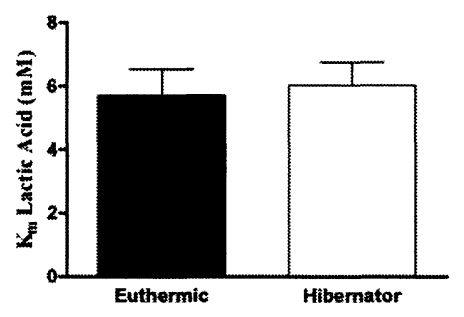

C

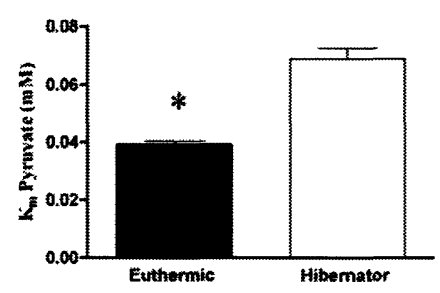

D

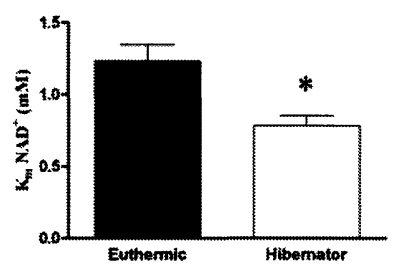

Figure 4.9: Kinetic parameters of skeletal muscle LDH from euthermic and hibernating $S$.

richardsonii showing $\mathrm{A}$ ) kinetic values for several kinetic variables with significant differences listed. Specifically, there was no significant difference between euthermic and hibernator $\mathrm{LA} \mathrm{K}_{\mathrm{m}}(\mathrm{B}: \mathrm{p}=0.8031)$ but there was a significant difference between euthermic and hibernator PYR $K_{m}(C: p=0.0002)$ and NAD $^{+} K_{m}(D: p<0.0154)$. Data are means \pm $\mathrm{SEM}, \mathrm{N}=4$. 
Incubations Promoting In Vitro Phosphorylation or Dephosphorylation:

Liver: Lactic Acid Direction:

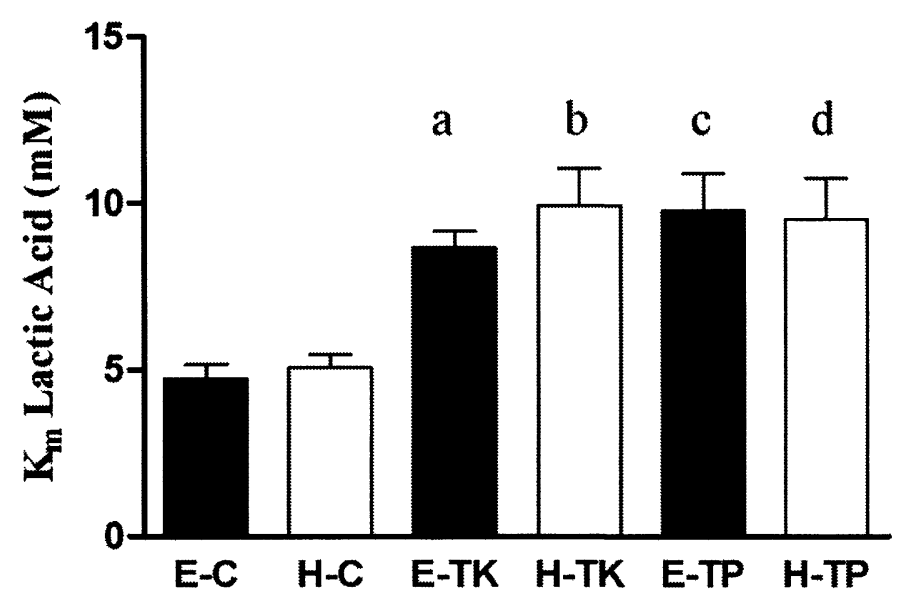

Figure 4.10: Effect of incubations under conditions that stimulate the action of protein kinases or protein phosphatases on the $\mathrm{K}_{\mathrm{m}} \mathrm{LA}$ of LDH from crude extracts of liver for euthermic versus hibernating $S$. richardsonii (See Methods for incubation conditions). Kinase conditions both stimulated endogenous protein kinases and contained $1 \mathrm{U}(10 \mu \mathrm{l})$ commercial PKA enzyme. Conditions are: $\mathrm{E}-\mathrm{C}=$ Euthermic Control, $\mathrm{H}-\mathrm{C}=$ Hibernator

Control, E-TK = Euthermic Total Kinase, H-TK = Hibernator Total Kinase, E-TP = Euthermic Total Phosphatase and H-TP = Hibernator Total Phosphatase. Upon kinase stimulation, $K_{m}$ values were significantly increased for euthermic (a: $\left.p=0.0018\right)$ and hibernator $(\mathrm{b}: \mathrm{p}=0.0057)$ forms compared to respective controls. After phosphatase stimulation, $K_{m}$ values were also significantly increased for euthermic $(c: p=0.0051)$ and hibernator $(\mathrm{d}: \mathrm{p}=0.0115)$ forms as compared to respective controls. Data are means \pm SEM, $\mathrm{N}=4$. 


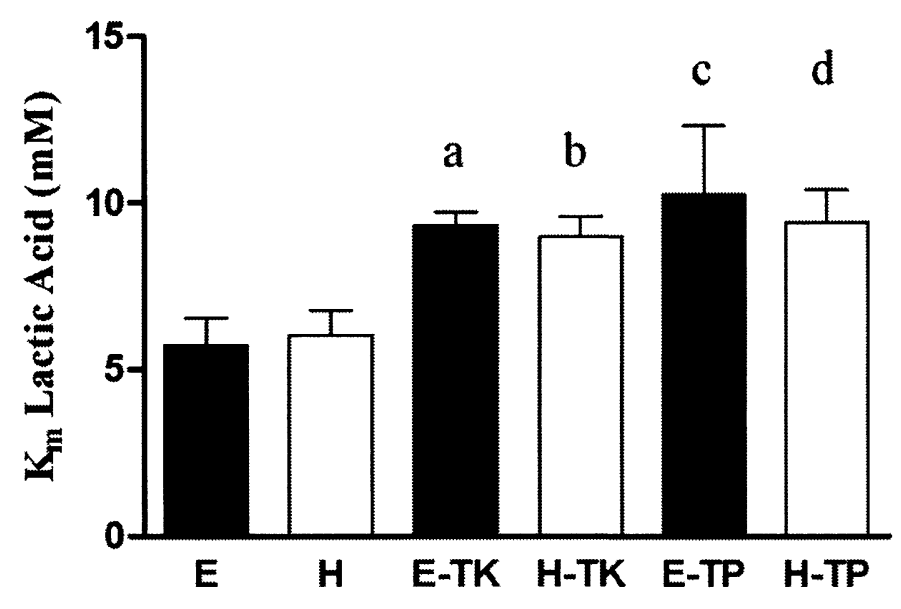

Figure 4.11: Effect of incubations under conditions that stimulate the action of protein kinases or protein phosphatases on the $\mathrm{K}_{\mathrm{m}} \mathrm{LA}$ of $\mathrm{LDH}$ from crude extracts of muscle for euthermic versus hibernating $S$. richardsonii (See Methods for incubation conditions). Kinase conditions both stimulated endogenous protein kinases and contained $1 \mathrm{U}(10 \mu \mathrm{l})$ commercial PKA enzyme. Conditions are: $\mathrm{E}-\mathrm{C}=$ Euthermic Control, $\mathrm{H}-\mathrm{C}=$ Hibernator Control, E-TK = Euthermic Total Kinase, H-TK = Hibernator Total Kinase, E-TP = Euthermic Total Phosphatase and H-TP $=$ Hibernator Total Phosphatase. Upon kinase stimulation, $K_{m}$ values were significantly increased for euthermic ( $a: p=0.0213$ ) and hibernator ( $\mathrm{b}: \mathrm{p}=0.0502)$ forms compared to respective controls. After phosphatase stimulation, $K_{m}$ values were also significantly different for euthermic (c: $p=0.0051$ ) but not hibernator $(\mathrm{d}: \mathrm{p}=0.0879)$ forms compared to respective controls. Data are means \pm SEM, $\mathrm{N}=4$. 
Incubations Promoting In Vitro Phosphorylation or Dephosphorylation:

Muscle: Pyruvate Direction:

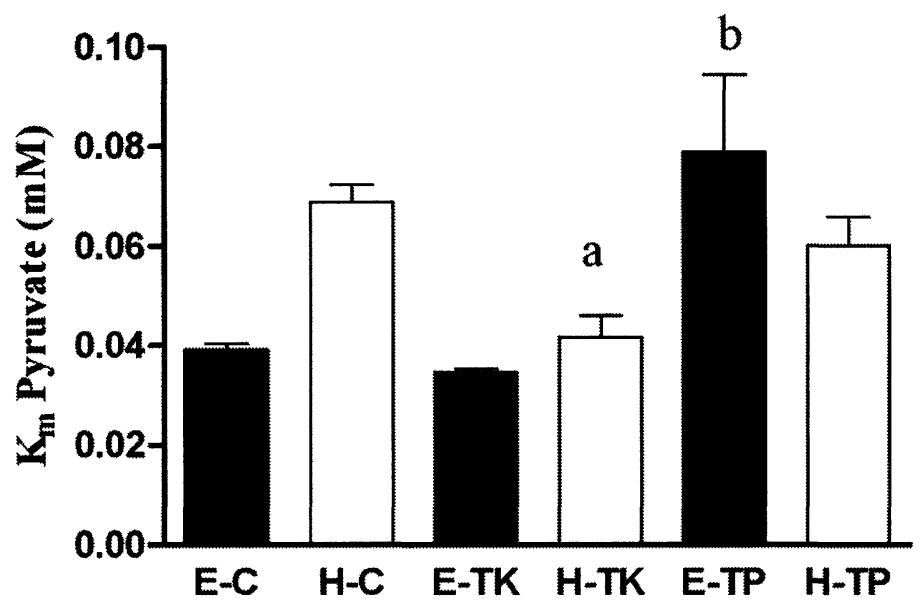

Figure 4.12: Effect of incubations under conditions that stimulate the action of protein kinases or protein phosphatases on the $\mathrm{K}_{\mathrm{m}}$ pyruvate of LDH from crude extracts of muscle for euthermic versus hibernating $S$. richardsonii (See Methods for incubation conditions). Kinase conditions both stimulated endogenous protein kinases and contained $1 \mathrm{U}(10 \mu \mathrm{l})$ commercial PKA enzyme. Conditions are: $\mathrm{E}-\mathrm{C}=$ Euthermic Control, $\mathrm{H}-\mathrm{C}=$ Hibernator Control, E-TK = Euthermic Total Kinase, H-TK = Hibernator Total Kinase, E-TP $=$ Euthermic Total Phosphatase and H-TP = Hibernator Total Phosphatase. Upon kinase stimulation, $\mathrm{K}_{\mathrm{m}}$ value was significantly decreased for the hibernator forms (a: $\mathrm{p}=0.0043$ ) compared to controls whereas after phosphatase stimulation, $\mathrm{K}_{\mathrm{m}}$ values were significantly increased for the euthermic forms $(b: p=0.0289)$ compared to its control. Data are means $\pm \mathrm{SEM}, \mathrm{N}=4$. 


\section{Arrhenius Plots and Activation Energies: Liver}

$\mathbf{A}$

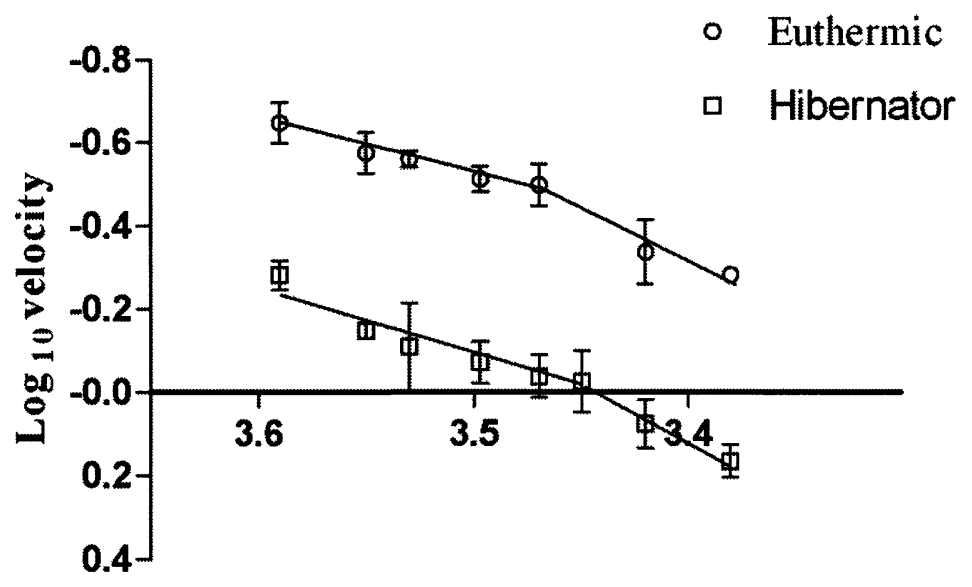

$1 / \mathrm{K} \times 10^{-3}$

B

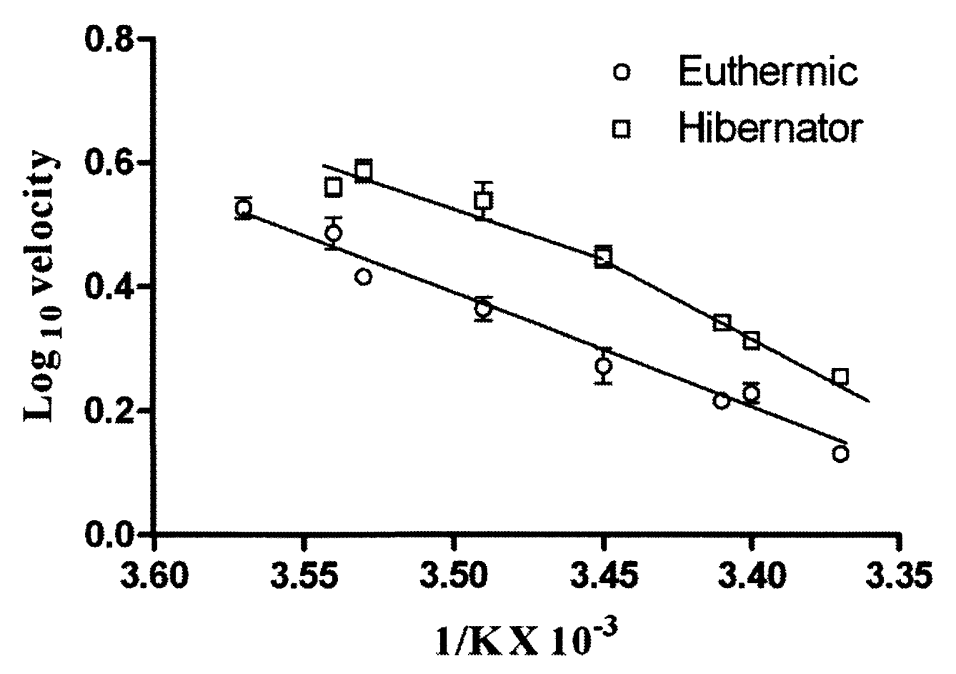

Figure 4.13: Arrhenius plots showing the effect of temperature on liver LDH from euthermic and hibernating $S$. richardsonii. Assay conditions for the LA-utilizing direction a $200 \mu 1$ well: (A) $20 \mathrm{mM}$ phosphate buffer (adjusted to $\mathrm{pH} 9.5$ at $23^{\circ} \mathrm{C}$ ), and (B) $20 \mathrm{mM}$ imidazole buffer (adjusted to $\mathrm{pH} 7.4$ at $23^{\circ} \mathrm{C}$ ) each with $3 \mathrm{mM} \mathrm{NAD}^{+}, 12.5 \mathrm{mM} \mathrm{LA}, 20$

$\mu \mathrm{L}$ of $500 \mathrm{X}$ crude supernatant. Both buffers were allowed to change $\mathrm{pH}$ with temperature. Data are means $\pm \mathrm{SEM}, \mathrm{N}=4$ 


\section{Arrhenius Plots and Activation Energies: Muscle}

$\mathbf{A}$

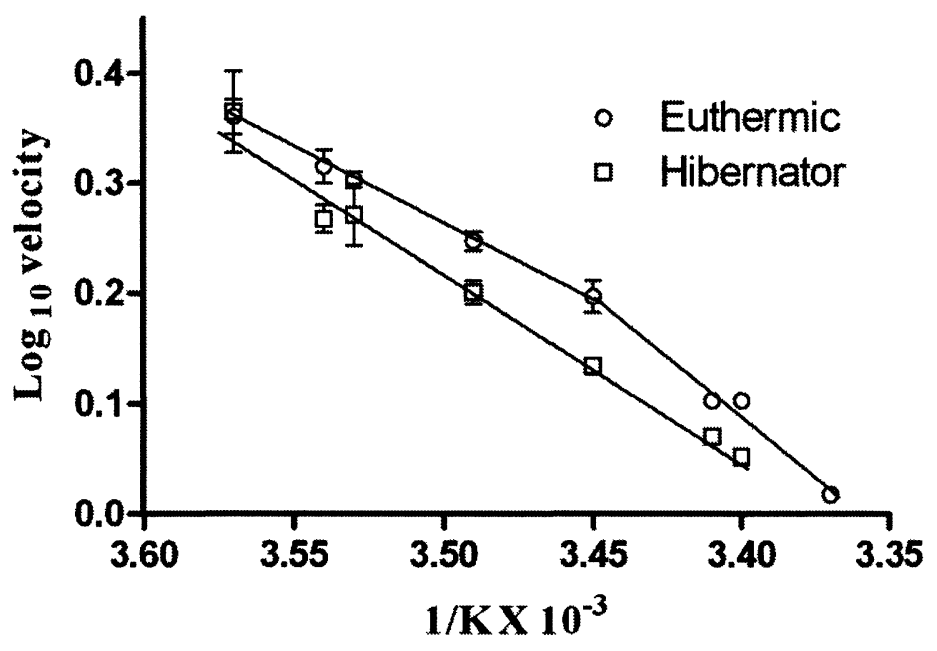

B

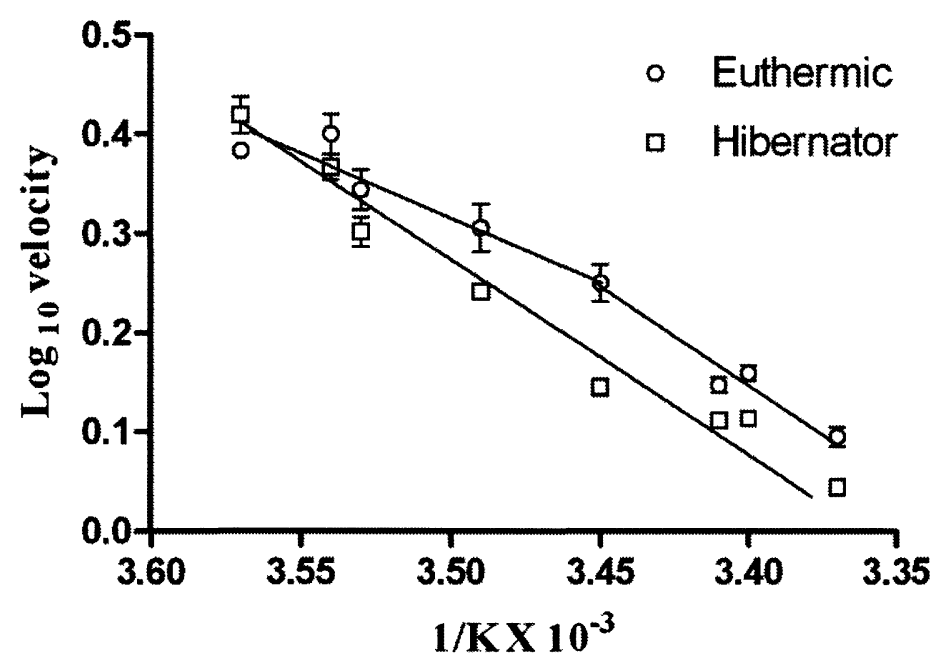

Figure 4.14: Arrhenius plots showing the effect of temperature on muscle LDH from euthermic and hibernating $S$. richardsonii. Assay conditions for a $200 \mu 1$ well for the LAutilizing direction are: (A) $20 \mathrm{mM}$ phosphate buffer (adjusted to $\mathrm{pH} 9.5$ at $23^{\circ} \mathrm{C}$ ), and (B) $20 \mathrm{mM}$ imidazole buffer (adjusted to $\mathrm{pH} 7.4$ at $23^{\circ} \mathrm{C}$ ) each with $3 \mathrm{mM} \mathrm{NAD}^{+}, 12.5 \mathrm{mM}$ LA, $20 \mu \mathrm{L}$ of $500 \mathrm{X}$ crude supernatant. Both buffers were allowed to change $\mathrm{pH}$ with temperature. Data are means $\pm \mathrm{SEM}, \mathrm{N}=4$. 


\section{Arrhenius Plots and Activation Energies:}

$\mathbf{A}$

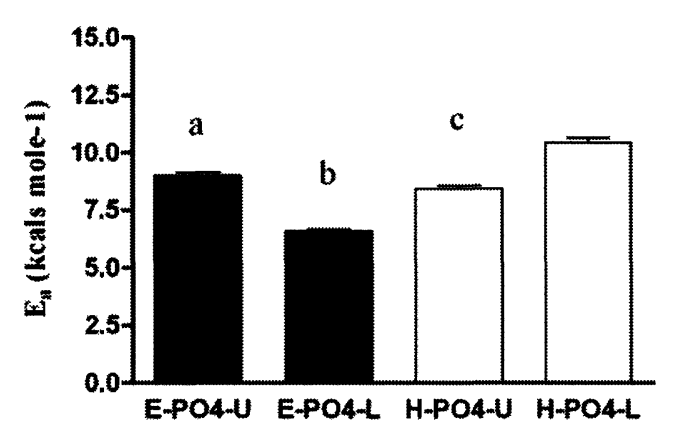

B

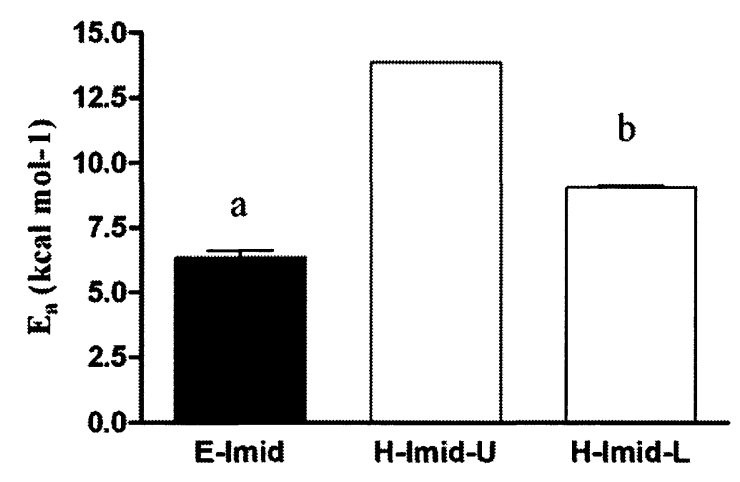

Figure 4.15: Calculated activation energies $\left(E_{a}\right)$ for the LA utilizing direction in liver of LDH from euthermic and hibernating S. richardsonii assayed in A) phosphate buffer (adjusted to $\mathrm{pH} 9.5$ at $23^{\circ} \mathrm{C}$ ) or B) $20 \mathrm{mM}$ imidazole (adjusted to $\mathrm{pH} 7.4$ at $23^{\circ} \mathrm{C}$ ). Both buffers were allowed to change $\mathrm{pH}$ with temperature. There is a significant difference between euthermic and hibernator activation energies in both tissues. In the phosphate system, there is a significant difference between upper and lower $E_{a}$ for euthermic (a: $\mathrm{p}<0.0001, \mathrm{~N}=4$ ) and hibernator ( $\mathrm{c}: \mathrm{p}<0.0001, \mathrm{~N}=4$ ). There is also a significant difference between euthermic lower and hibernator upper ( $b: p<0.0001, N=4)$ with even greater significance between euthermic lower and hibernator lower. In the imidazole system, there is a significant difference between hibernator upper and hibernator lower (b: $\mathrm{p}<0.0001, \mathrm{~N}=4)$. Both hibernator $\mathrm{E}_{\mathrm{a}}$ are significantly higher than the euthermic $\mathrm{E}_{\mathrm{a}}(\mathrm{a}$ : $\mathrm{p}<0.0001, \mathrm{~N}=4)$. E-PO4-U= Euthermic Phosphate Upper, E-PO4-L= Euthermic

Phosphate Lower, H-PO4-U= Hibernator Phosphate Upper, H-PO4-L= Hibernator Phosphate Lower, E-Imid= Euthermic Imidazole, H-Imid-U= Hibernator Imidazle Upper, H-Imid-L $=$ Hibernator Imidazole Lower. 


\section{Arrhenius Plots and Activation Energies:}

A

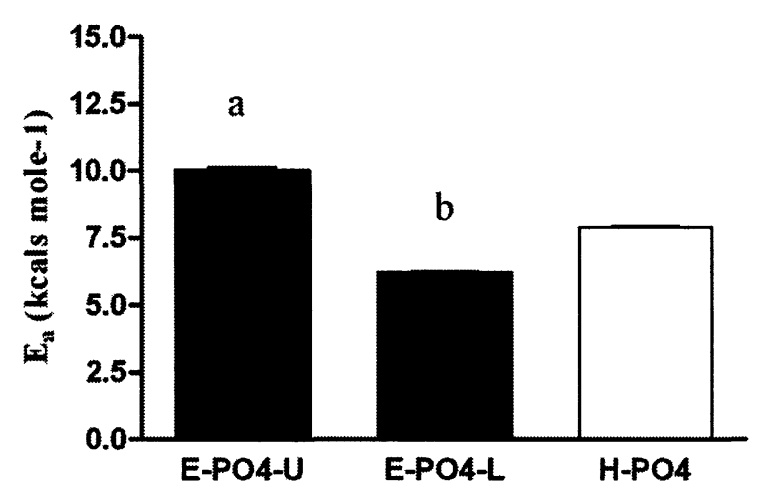

B

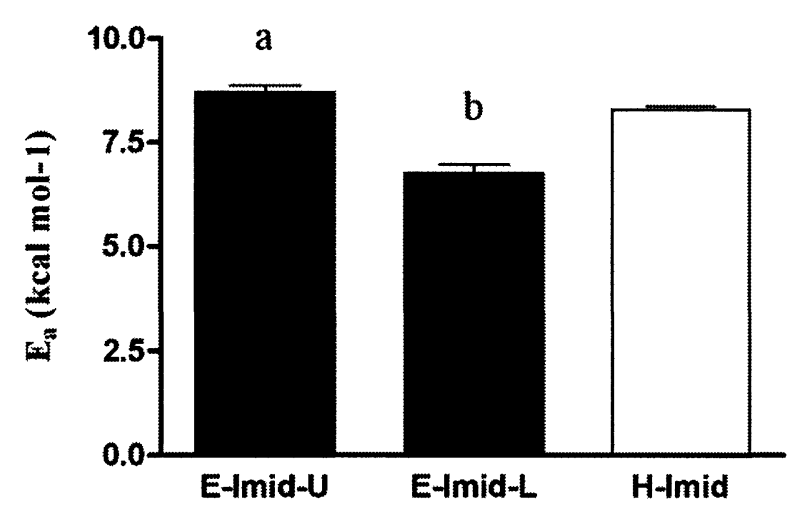

Figure 4.16: Calculated activation energies $\left(E_{a}\right)$ for the LA utilizing direction in muscle of $\mathrm{LDH}$ from euthermic and hibernating $S$. richardsonii assayed in A) phosphate buffer (adjusted to $\mathrm{pH} 9.5$ at $23^{\circ} \mathrm{C}$ ) or B) $20 \mathrm{mM}$ imidazole (adjusted to $\mathrm{pH} 7.4$ at $23^{\circ} \mathrm{C}$ ). Both buffers were allowed to change $\mathrm{pH}$ with temperature. There is a significant difference between euthermic and hibernator activation energies in both tissues. In the phosphate system, there is a significant difference between upper and lower $E_{a}$ for euthermic (a: $\mathrm{p}<0.0001, \mathrm{~N}=4)$. There is also a significant difference between euthermic lower and hibernator ( $b: \mathrm{p}<0.0001, \mathrm{~N}=4$ ). In the imidazole system, there is a significant difference between euthermic upper and lower $(a: p=0.0003, N=4)$ as well as euthermic lower and hibernator ( $b: \mathrm{p}=0.0003, \mathrm{~N}=4$ ). E-PO4-U= Euthermic Phosphate Upper, E-PO4-L= Euthermic Phosphate Lower, H-PO4 = Hibernator Phosphate, E-Imid= Euthermic Imidazole, $\mathrm{H}$-Imid= Hibernator Imidazole. 


\section{Km vs Temperature Curves:}

A

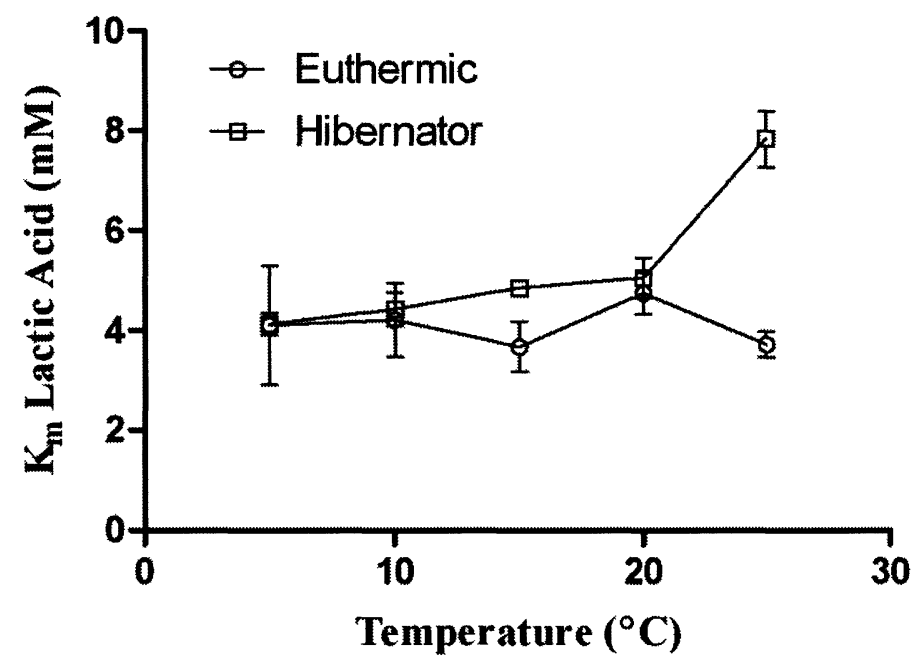

B

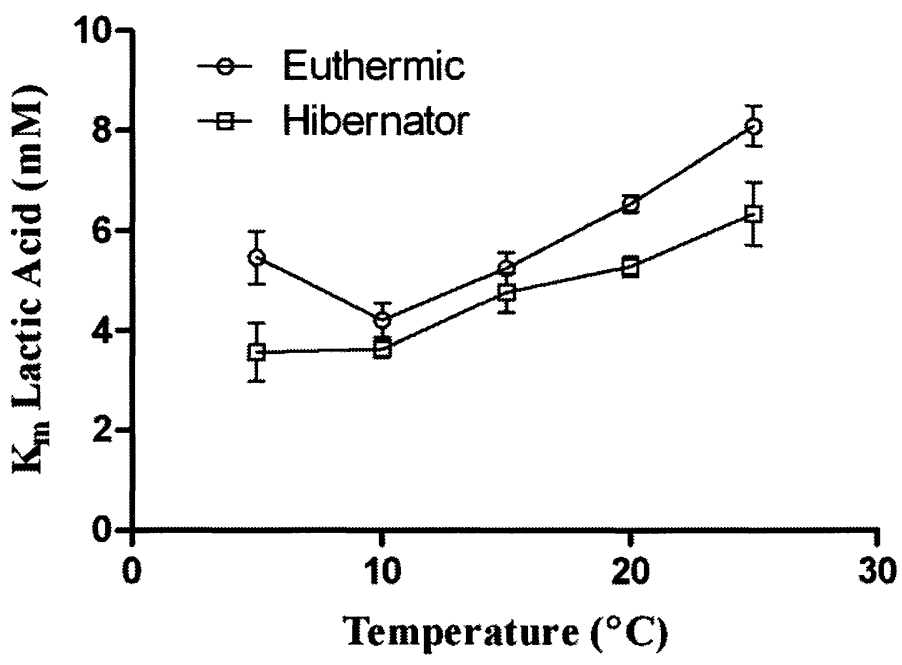

Figure 4.17: $\mathrm{K}_{\mathrm{m}}$ LA vs temperature curves for A) liver and B) muscle LDH from euthermic and hibernating $S$. richardsonii. Assays were performed in imidazole buffer adjusted to $\mathrm{pH} 7.4$ at $23^{\circ} \mathrm{C}$ and allowed to fluctuate with temperature. Assay conditions for a $200 \mu \mathrm{L}$ well in the lactic acid utilizing direction: $20 \mathrm{mM}$ imidazole $\mathrm{pH} 7.4,3 \mathrm{mM}$ $\mathrm{NAD}^{+}, 12.5 \mathrm{mM}$ lactic acid and $10 \mu \mathrm{L}$ of $500 \mathrm{X}$ diluted crude supernatant. Data are means $\pm \mathrm{SEM}, \mathrm{N}=4$. 
$\mathbf{A}$

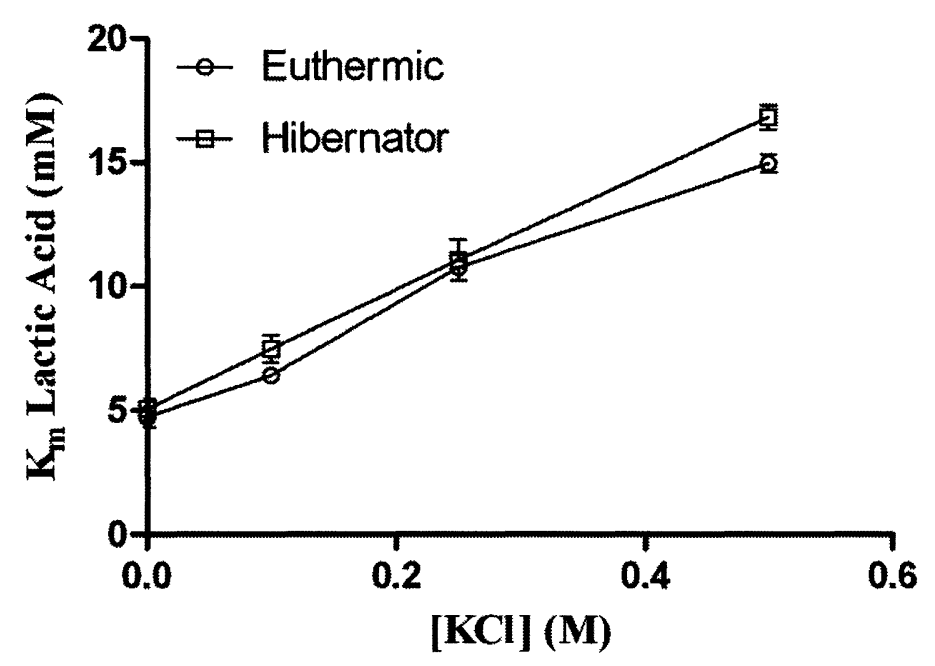

B

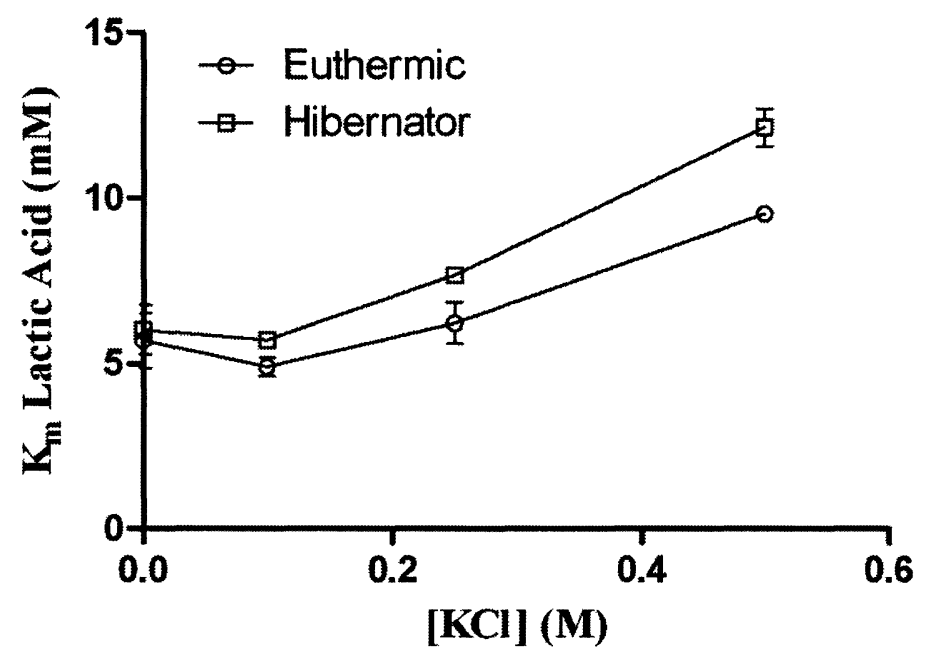

Figure 4.18: Effect of high $\mathrm{KCl}$ concentrations on $\mathrm{K}_{\mathrm{m}} \mathrm{LA}$ of $\mathrm{A}$ ) liver and $\mathrm{B}$ ) muscle LDH from euthermic and hibernating $S$. richardsonii. Assays were performed in phosphate buffer adjusted to $\mathrm{pH} 9.5$ at $23^{\circ} \mathrm{C}$. Assay conditions for a $200 \mu \mathrm{L}$ well in the lactic acid utilizing direction: $20 \mathrm{mM}$ phosphate $\mathrm{pH} 9.5,3 \mathrm{mM} \mathrm{NAD}^{+}$, various concentrations of lactic acid and $10 \mu \mathrm{L}$ of $500 \mathrm{X}$ diluted crude supernatant. Data are means $\pm \mathrm{SEM}, \mathrm{N}=4$. 
Salt Effects: Immediate:

A

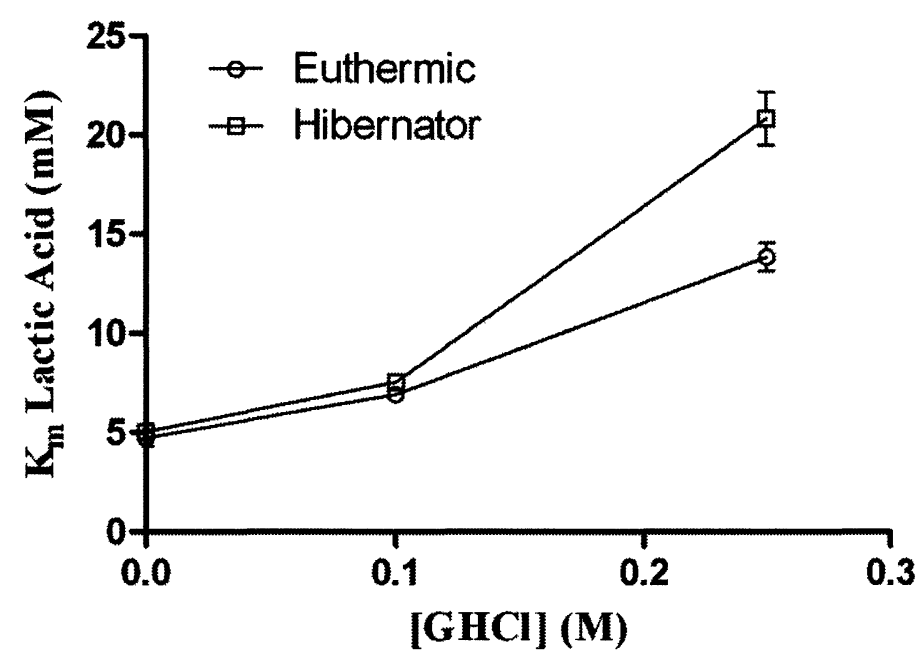

B

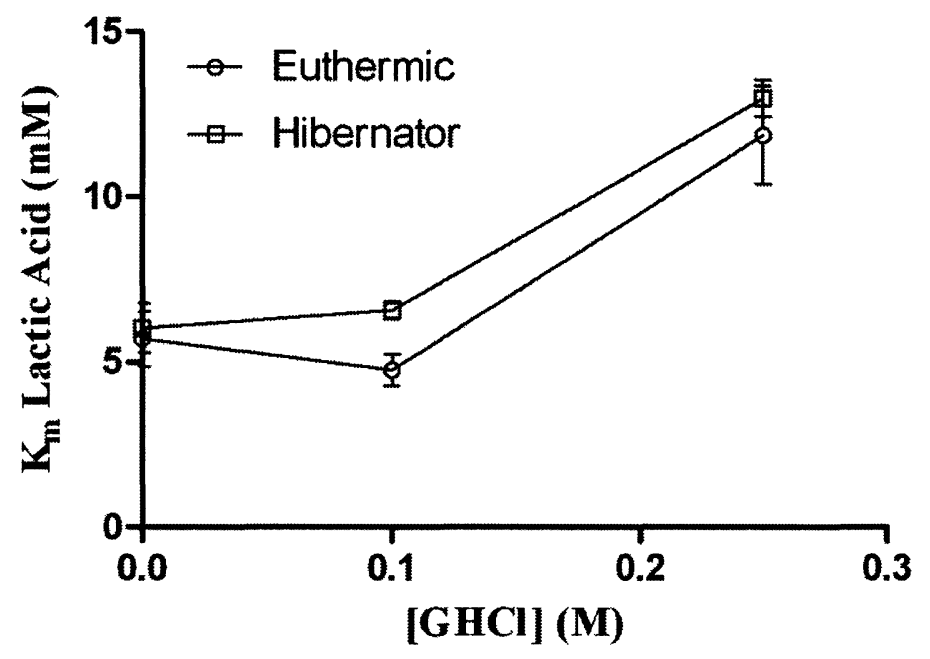

Figure 4.19: Effect of high $\mathrm{GHCl}$ concentrations on $\mathrm{K}_{\mathrm{m}} \mathrm{LA}$ of $\mathrm{A}$ ) liver and B) muscle LDH from euthermic and hibernating $S$. richardsonii. Assays were performed in phosphate buffer adjusted to $\mathrm{pH} 9.5$ at $23^{\circ} \mathrm{C}$. Assay conditions for a $200 \mu \mathrm{L}$ well in the lactic acid utilizing direction: $20 \mathrm{mM}$ phosphate $\mathrm{pH} 9.5,3 \mathrm{mM} \mathrm{NAD}^{+}$, various concentrations of lactic acid and $10 \mu \mathrm{L}$ of $500 \mathrm{X}$ diluted crude supernatant. Data are means $\pm \mathrm{SEM}, \mathrm{N}=4$. 
Salt Effects: Immediate:

A

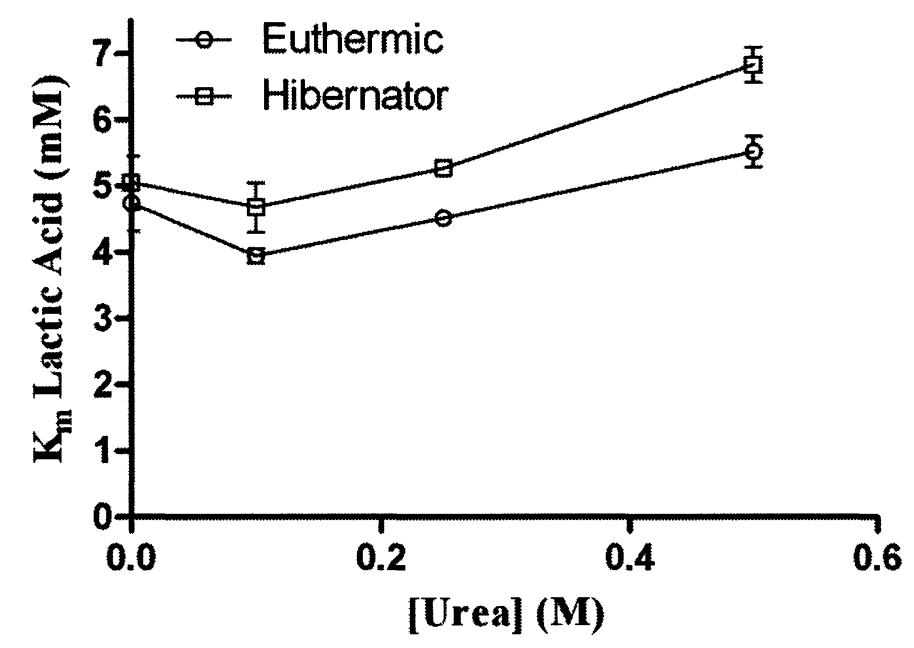

B

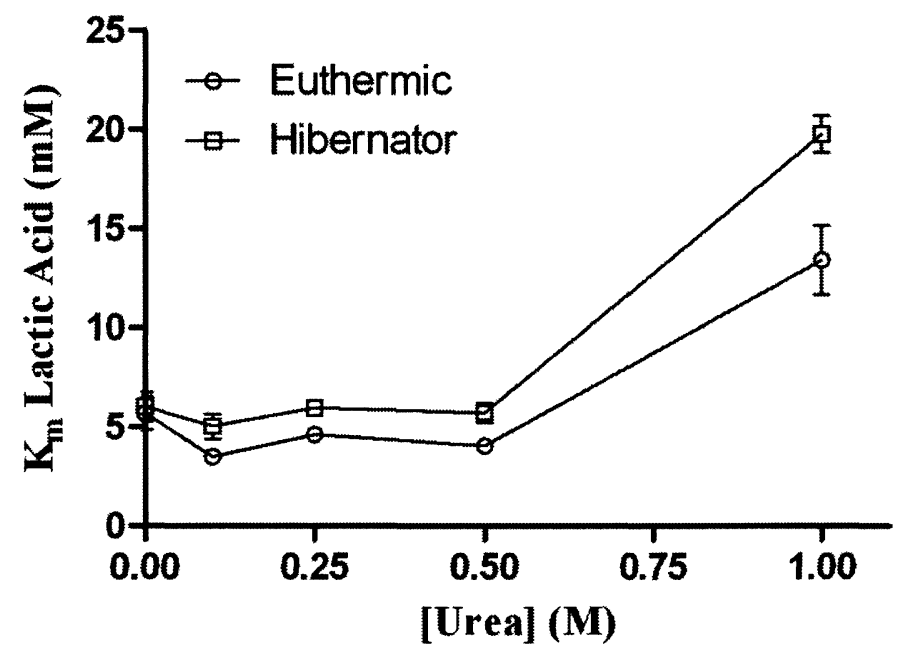

Figure 4.20: Effect of high urea concentrations on $\mathrm{K}_{\mathrm{m}}$ LA of A) liver and B) muscle LDH from euthermic and hibernating $S$. richardsonii. Assays were performed in phosphate buffer adjusted to $\mathrm{pH} 9.5$ at $23^{\circ} \mathrm{C}$. Assay conditions for a $200 \mu \mathrm{L}$ well in the lactic acid utilizing direction: $20 \mathrm{mM}$ phosphate $\mathrm{pH} 9.5,3 \mathrm{mM} \mathrm{NAD}^{+}$, various concentratons of LA and $10 \mu \mathrm{L}$ of $500 \mathrm{X}$ diluted crude supernatant. Data are means $\pm \mathrm{SEM}, \mathrm{N}=4$. 
Salt Effects: Urea Incubations and $\mathbf{I}_{50}$ Values:

$\mathbf{A}$

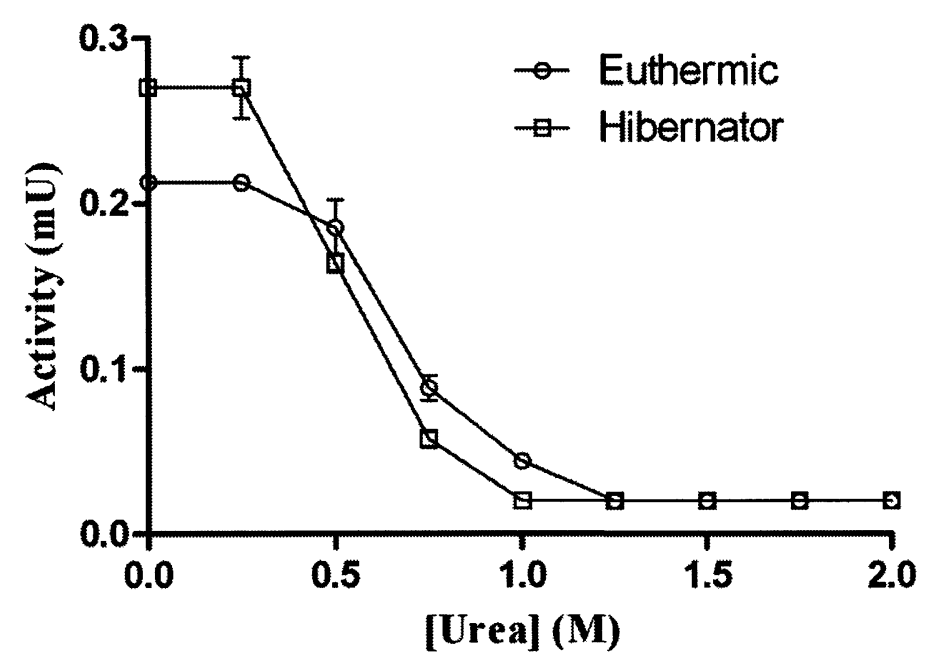

B

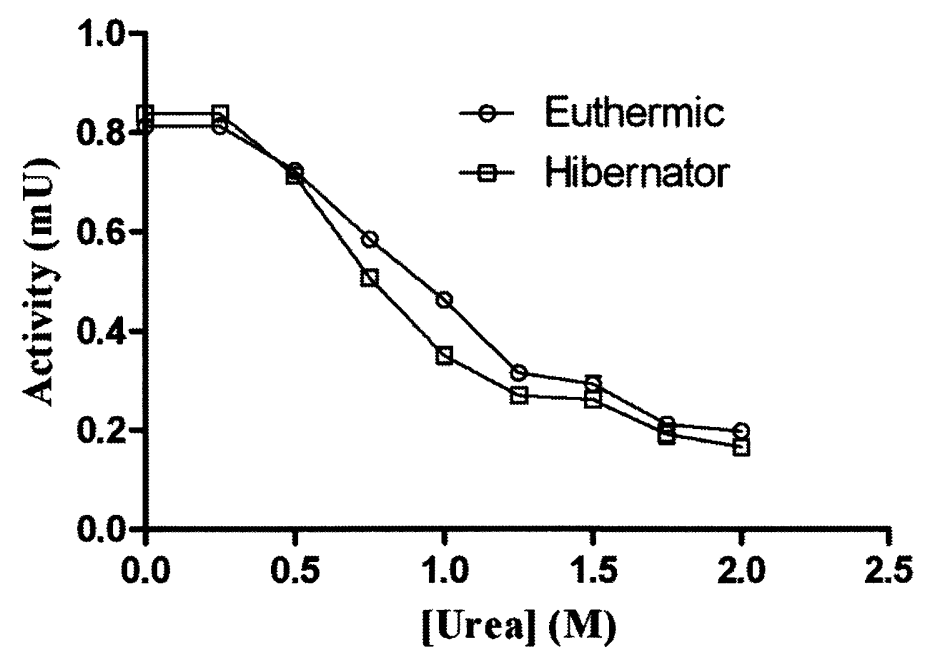

Figure 4.21: Effect of urea on A) liver and B) muscle LDH maximal activity from euthermic and hibernating $S$. richardsonii: Effect of incubation for 15 minutes at different urea concentrations (0-2 M) followed by assay in the LA utilizing direction for activity. In both tissues, calculated $\mathrm{I}_{50}$ values show that the hibernator form is more susceptible to urea denaturation. Data are means $\pm \mathrm{SEM}, \mathrm{N}=3$. 
Denaturant Effects: Urea Incubations and $I_{50}$ Values:

$\mathbf{A}$

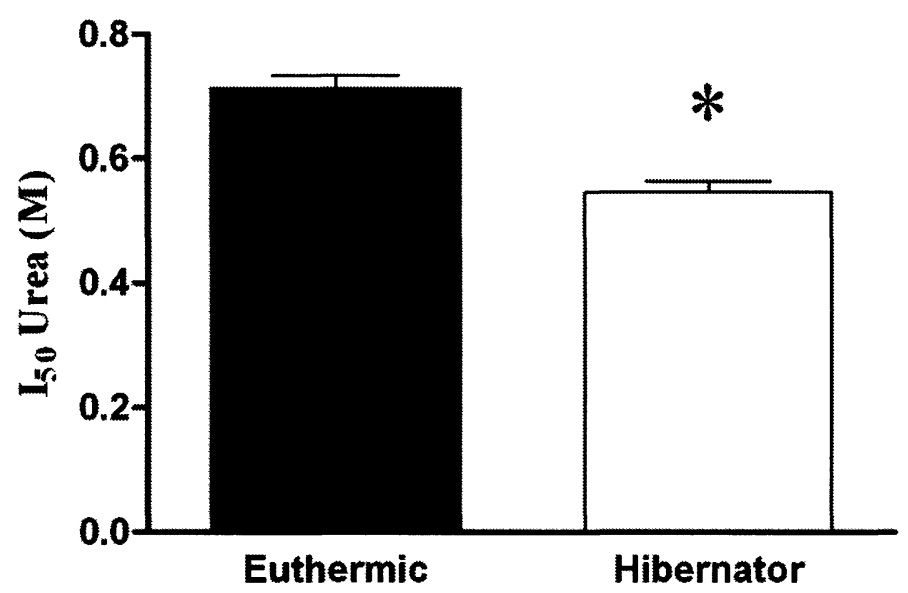

B

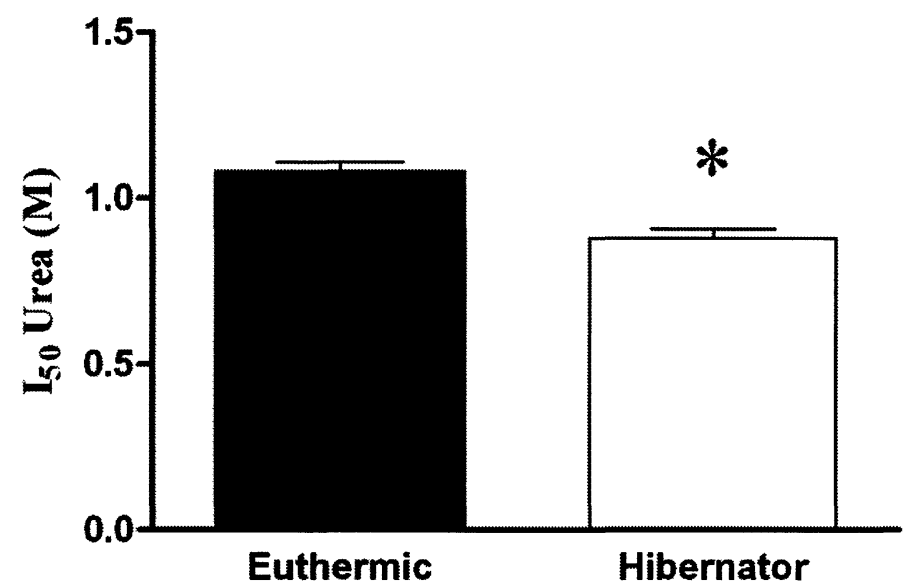

Figure 4.22: $\mathrm{I}_{50}$ values for urea inhibition of A) liver and B) muscle LDH from euthermic and hibernating $S$. richardsonii. Enzyme was incubated for 15 minutes at different urea concentrations (0-2 M) followed by assay of activity in the LA utilizing direction. There is a significant difference in $\mathrm{I}_{50}$ values between euthermic and hibernating conditions for both liver $(\mathrm{p}=0.001)$ and muscle $(\mathrm{p}=0.0077)$ showing that the hibernator form more susceptible to urea denaturation in both tissues. Data are means $\pm \mathrm{SEM}, \mathrm{N}=3$. 


\section{Denaturant Effects: Incubations for Phosphorylation Stability}

\section{Liver:}

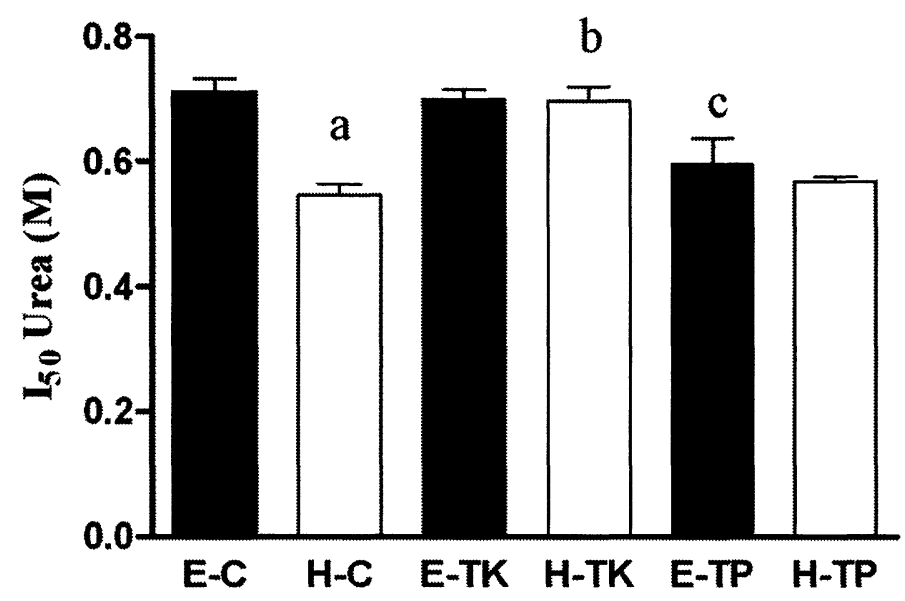

Figure 4.23: Effect of incubations under conditions that stimulate the action of protein kinases or protein phosphatases on the on urea $\mathrm{I}_{50}$ of $\mathrm{LDH}$ from crude extracts of liver for euthermic versus hibernating $S$. richardsonii (See Methods for incubation conditions). Kinase conditions both stimulated endogenous protein kinases and contained $1 \mathrm{U}(10 \mu \mathrm{l})$ commercial PKA enzyme. Conditions are: $\mathrm{E}-\mathrm{C}=$ Euthermic Control, $\mathrm{H}-\mathrm{C}=$ Hibernator Control, E-TK = Euthermic Total Kinase, H-TK = Hibernator Total Kinase, E-TP = Euthermic Total Phosphatase and H-TP = Hibernator Total Phosphatase. Incubations were at $5^{\circ} \mathrm{C}$ for 48 hours and then subjected to urea denaturing. There is a significant difference between euthermic and hibernator control $I_{50}$ values $(a: p=0.001)$. Stimulation of total kinase activity increased urea stability of the hibernator enzyme compared to hibernator control levels ( $\mathrm{b}: \mathrm{p}=0.0018)$ whereas stimulation of total phosphatases significantly decreased the urea stability of the euthermic form compared to euthermic control (c: $\mathrm{p}=0.0425)$ Data are means $\pm \mathrm{SEM}, \mathrm{N}=4$. 
Denaturant Effects: Incubations for Phosphorylation Stability

\section{Muscle:}

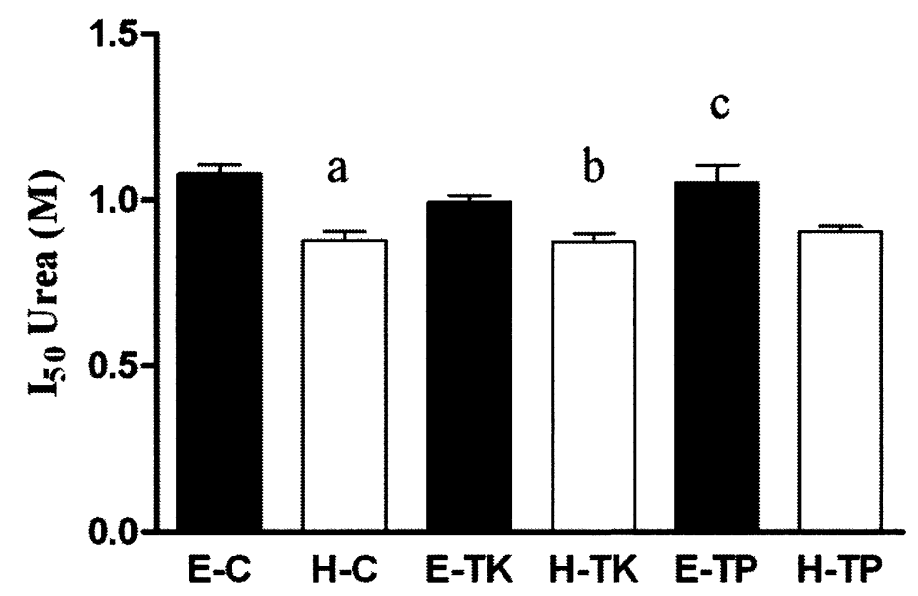

Figure 4.24: Effect of incubations under conditions that stimulate the action of protein kinases or protein phosphatases on urea $\mathrm{I}_{50}$ of $\mathrm{LDH}$ from crude extracts of muscle for euthermic versus hibernating $S$. richardsonii (See Methods for incubation conditions). Kinase conditions both stimulated endogenous protein kinases and contained $1 \mathrm{U}(10 \mu \mathrm{l})$ commercial PKA enzyme. Conditions are: $\mathrm{E}-\mathrm{C}=$ Euthermic Control, $\mathrm{H}-\mathrm{C}=$ Hibernator

Control, E-TK = Euthermic Total Kinase, H-TK = Hibernator Total Kinase, E-TP = Euthermic Total Phosphatase and H-TP = Hibernator Total Phosphatase. Incubations were at $5^{\circ} \mathrm{C}$ for 48 hours. There is a significant difference between euthermic and hibernator control $\mathrm{I}_{50}$ values ( $\left.\mathrm{a}: \mathrm{p}=0.0077\right)$. Stimulation for total kinases had no effect on urea stability of the hibernator enzyme compared to hibernator control $(b: p=0.9348)$ and stimulation of total phosphatases had no effect on the urea stability of the euthermic form compared to euthermic control (c: $\mathrm{p}=0.6840)$ Data are means $\pm \mathrm{SEM}, \mathrm{N}=4$. 


\section{Discussion}

LDH has been extensively studied in many mammalian systems and is generally considered to be a high activity equilibrium enzyme with some regulatory functions, for example, the heart isozyme shows strong product inhibition by LA but the muscle form does not. Some studies have reported that distribution of $\mathrm{LDH}$ between tetramer and dimer forms can have regulatory consequences (Yamamoto and Storey, 1988). LDH subunits have also been found to be translocated into the mitochondria (Van Hall, 2000) and differential expression of LDH subunits in response to stress has also been reported (Moon, 1978). However, evidence that LDH is regulated by PTM has generally been lacking. Typically it is state-specific changes in enzyme kinetic properties that first hint at PTM of an enzyme, but some enzymes undergo reversible phosphorylation for other reasons such as to alter protein stability, to modify protein-protein interactions, or to translocate or compartmentalization the enzyme. The present study was undertaken to reevaluate $\mathrm{LDH}$ and determine if the enzyme might undergo differential phosphorylation in response to transitions between euthermic and hibernating states in ground squirrel liver and muscle and, if so, what changes in kinetic properties or stability of LDH are associated with a change in phosphorylation state.

\section{pH optima}

The $\mathrm{pH}$ optimum for the LA utilizing direction in both tissues was approximately 10, which is quite basic (Fig 4.2), whereas in the pyruvate utilizing direction, there was a broader optimum at physiological pH (Fig 4.3). This is common for LDHs and the $\mathrm{pH}$ optimum of the pyruvate utilizing direction sets up the enzyme to work easily as the 
$\mathrm{NAD}^{+}$recycling enzyme during intense muscle work or under anaerobic conditions. Since most tissues of hibernators show a relative acidification during torpor, the LA oxidizing direction might be less favored during torpor than in euthermia but LA doesn't accumulate during torpor since metabolism is based mainly on aerobic lipid oxidation.

\section{Partial Purification and Phosphoprotein Analysis}

Purification of $\mathrm{LDH}$ to homogeneity was problematic with multiple methods tried but unsatisfactory. However, elution off a weak cation exchange column, CM, provided sharp peaks (Fig 4.4, 4.5) with enough activity and an adequate purification factor. This provided enough protein to detect clear immunoreactive bands at $\sim 35 \mathrm{kD}$ on SDS-PAGE (Fig 4.6). Western blotting also showed that there were comparable amounts of enzyme in euthermic and hibernating states in both tissues indicating that there is no coarse control regulation of LDH content between the two states. However, analysis of the content of phosphoprotein showed a strong difference between euthermic and hibernating conditions. Band intensity was much stronger for the euthermic enzyme from both tissues and during torpor the relative amount of phosphorylated LDH decreased by $74 \%$ in liver and $34 \%$ in muscle as compared with the euthermic form (Fig 4.7). This indicates that the euthermic and hibernator forms are the high and low phosphate forms, respectively.

\section{Kinetics}

LDH in the liver and muscle share the same isoform, M4. This isoform has been reported to be more effective in the pyruvate utilizing direction (Moon, 1978). This would make sense as the main use of $\mathrm{LDH}$ in muscle is to support high intensity glycolytic activity during muscle work. Active muscle tissue would not reverse the LA 
back to pyruvate but rather export lactate for reconversion to glucose by gluconeogenesis in the liver (the Cori cycle) or to use as an aerobic substrate in tissues such as heart.

The $\mathrm{Km}$ for LA was unaffected in liver and muscle between euthermic and hibernating states (Fig 4.8 B) but the maximal activity of liver LDH (in the LA utilizing direction) was much lower in euthermia versus torpor (Fig $4.8 \mathrm{~A}$ ). The opposite was true for muscle with the hibernator form having a lower activity in the LA utilizing direction. These activity shifts might be accounted for by a disassociation of the tetramer structure at low temperatures in hibernators that has been reported in other hibernating mammals (Somero, 1995). There was a clear difference in $\mathrm{K}_{\mathrm{m}} \mathrm{NAD}^{+}$between the two states for liver LDH, with a nearly 4-fold higher $\mathrm{K}_{\mathrm{m}}$ for the hibernator enzyme (Fig $4.8 \mathrm{D}$ ). However, the opposite effect was seen in muscle where the hibernator form had the greater affinity for $\mathrm{NAD}^{+}$(Fig 4.9 D). This might be explained by a possible extra modifier on $\mathrm{K}_{\mathrm{m}} \mathrm{NAD}^{+}$, such as scaffold binding (Storey and Storey, 2004), which would not be as prominent in liver. In the pyruvate utilizing direction, there was no change in the $\mathrm{K}_{\mathrm{m}}$ pyruvate values for liver LDH (Fig $4.8 \mathrm{C}$ ) but there is a reduction in maximal activity for the hibernator form which is expected (Fig $4.8 \mathrm{~A}$ ). The muscle responded quite differently with an increase in maximal activity during torpor (Fig $4.9 \mathrm{~A}$ ) as well as an increase in the $\mathrm{K}_{\mathrm{m}}$ pyruvate (affinity for pyruvate is reduced) (Fig $4.9 \mathrm{C}$ ). This is similar to other results found for muscle LDH from hibernating bats (Moon, 1978). 


\section{Incubations to stimulate Total Protein Kinases or Phosphatases}

Even though LDH showed limited substrate kinetic differences between euthermic and hibernating states, phosphorylation status could still change between the two states and potentially affect other enzyme parameters. Therefore, LDH was subjected to conditions that would stimulate kinase or phosphatase action on the protein. Upon kinase stimulation, the $\mathrm{K}_{\mathrm{m}}$ LA increased for both euthermic and hibernator forms in both liver and muscle (Fig 4.10, 4.11). Interestingly, LDH from both tissues responded similarly with $\mathrm{K}_{\mathrm{m}}$ values for the untreated enzyme being $\sim 5 \mathrm{mM}$ and doubling to $\sim 10$ $\mathrm{mM}$ after the kinase or phosphatase treatment. The data from ProQ staining certainly indicated that $\mathrm{LDH}$ is a phosphoprotein but the results from these incubations indicate that although in vitro phosphorylation or dephosphorylation clearly affect enzyme properties, they do not act on $\mathrm{K}_{\mathrm{m}} \mathrm{LA}$ in a reciprocal manner as would be expected if this PTM was physiologically important for modifying enzyme affinity for this substrate.

Interestingly, however, kinase/phosphatase incubations did have strong differential effects on the $K_{m}$ pyruvate. Incubations that stimulated kinase activities did not affect the euthermic enzyme but reduced hibernator $\mathrm{K}_{\mathrm{m}}$ pyruvate values by about $50 \%$ to a level similar to that in euthermia (Fig 4.12). Stimulation of phosphatases had the opposite effect. Phosphatase incubation increased the $\mathrm{K}_{\mathrm{m}}$ pyruvate of euthermic LDH to a value similar to the hibernator controls but phosphatase treatment had no effect on $\mathrm{K}_{\mathrm{m}}$ pyruvate of the hibernator form. These data suggest that reversible phosphorylation of LDH has a localized effect on pyruvate kinetics. 


\section{Arrhenius Plots and Activation Energy}

The activation energy of a reaction is the energy barrier that has to be overcome in order for the reaction to take place. In enzymatic reactions it is known as the Gibbs free energy. Enzymes in their working state are usually in their lowest energy form. Any modification to the enzyme will alter the energy state of the enzymatic system by increasing the overall energy of the system. An increase in the energy of the system translates to a decrease in the activation energy (Voet and Voet, 2004). Therefore any PTM to an enzyme in its ground state should affect the activation energy. The Arrhenius equation also reveals a possible temperature induced control over enzyme activity. Breaks in the Arrhenius linear relationship could be the result of temperature induced dissociation or change in conformation which could be a factor in enzymatic regulation (Mehrani and Storey, 1997). Changes in $\mathrm{pH}$ could also be a factor in regulating this enzyme. Therefore two buffer systems were chosen in order to more fully examine the effects of $\mathrm{pH}$ and temperature on the activation energy. Phosphate buffer was used as it has a very low change in $\mathrm{pH}$ with temperature. Imidazole was chosen as it mimics intracellular conditions. Two $\mathrm{pH}$ levels were chosen as well. The phosphate buffer was set to $\mathrm{pH} 9.5$ which is optimal for the LA utilizing reaction whereas imidazole was set to $\mathrm{pH} 7.4$ at $23^{\circ} \mathrm{C}$ so that its change in $\mathrm{pH}$ with temperature would mimic the intracellular response to cooling. Both buffer systems were allowed to fluctuate with temperature.

There was a difference in activation energies between the euthermic and hibernator forms with breaks in the Arrhenius linear relationship in both tissues and at different $\mathrm{pH}$ values (Fig 4.13, 4.14). The lower activation energy displayed by the lower temperature euthermic form in both liver and muscle (Fig 4.15, 4.16) suggests that this 
form could be structurally different (e.g. due to a PTM), which would increase the free energy of the system thereby significantly lowering the activation energy. It is also expected as the euthermic form is the more phosphorylated form and is the more functional form. The breaks in the plot suggest that this enzyme is partially temperature controlled. However, since the enzyme is a tetramer and it is likely that LDH subunits may be dissociated/translocated during torpor; this temperature control might be misleading with respect to direct effects on the enzyme. However, temperature control might be involved in the initial disassociation as hydrophobic bonds are destabilized at lower energy states or temperatures, energies that might be in excess of the stabilized Van der Walls, hydrogen and salt bonds (Hochachka and Somero, 1984) allowing for disassociation. The cooperative binding of the tetramer is lost during disassociation and thus the activation energy is increased. In the liver, there is a significant difference in the $E_{a}$ between euthermic upper and lower temperature range $(a: p<0.0001, N=4)$ in the phosphate system (Fig 4.15A). There is a clear shift in $\mathrm{E}_{\mathrm{a}}$ at lower temperatures with the euthermic form decreasing and the hibernator form increasing. There is also a significant difference in $\mathrm{E}_{\mathrm{a}}$ between euthermic lower temperature and hibernator lower temperature (b: $p<0.0001, N=4$ ). This shift raises the possibility of the PTM adjusting the $E_{a}$ allowing for the euthermic form to function at lower temperatures which would be desirable upon MRE. In the imidazole system (Fig 4.13 B, 4.15 B), the break in the linear plot occurs in the hibernator form only and therefore it is possible that LDH, upon phosphorylation during MRE, regains euthermic like activity. In the muscle, there are clear breaks in the euthermic plots in both buffer systems with the lower temperature form having reduced 
$E_{a}$ compared to the hibernator. This further supports the possibility of the PTM promoting more activity during MRE.

\section{Km vs Temperature Curves}

LDH $\mathrm{K}_{\mathrm{m}}$ and maximal activity decrease with decreasing temperature with the $\mathrm{Km}$ vs temperature curve following general trends (Fig 4.17). There was a clear kinetic difference over a $20^{\circ} \mathrm{C}$ range with activities and $\mathrm{K}_{\mathrm{m}}$ values reduced at $5^{\circ} \mathrm{C}$. The liver form did show some differential kinetics at $25^{\circ} \mathrm{C}$ with the euthermic form having a much lower $\mathrm{K}_{\mathrm{m}}$ LA. However, there were no kinetic differences at any other temperature or in muscle.

\section{Denaturant Effects}

Another possible reason for PTM of enzymes is to alter their stability in the face of selected stresses. A key part of energy savings that contribute to metabolic suppression during torpor is strongly reduced rates of ATP-expensive gene transcription, protein translation, and protein degradation (Storey and Storey, 2004). What this means is that to maintain cellular homeostasis, the half-life of macromolecules must be greatly extended and therefore mechanisms that increase stability or help macromolecules to resist denaturation become important (Hoffmann and Radeke, 1978). The altered cellular environment during torpor could include some amount of dehydration (which could increase ionic strength) as well as an increase in urea concentration as a result of a continuing low level of protein catabolism. Liver and muscle LDH showed a limited ability to resist changes in ionic strength greater than $100 \mathrm{mM}$ in both $\mathrm{KCl}$ (Fig 4.18) and GHCl (Fig 4.19). Resistance to urea was greater than for the other denaturants with urea 
levels that were less than or equal to $500 \mathrm{mM}$ having little effect on $\mathrm{K}_{\mathrm{m}}$ LA values (Fig 4.20). Kinetics between euthermic and hibernator forms in the presence of these denaturants was similar.

However, the effects of extended incubation with urea showed that the $\mathrm{I}_{50}$ values for the euthermic form in both liver and muscle were greater than the hibernator form indicating that the euthermic enzyme has greater stability (Fig 4.21, 4.22). Furthermore, muscle LDH showed higher $\mathrm{I}_{50}$ values than the liver form indicating greater overall stability of the muscle form. Stability in urea is important since urea concentration increases during torpor (Abnous and Storey, 2007) but more importantly susceptibility to urea denaturation is also a measure of the flexibility vs rigidity of enzyme conformation. In both tissues the comparison of euthermic versus hibernator LDH indicated greater flexibility of the hibernator protein which is a positive attribute for a protein that must retain functionality over a wide temperature range. Greater flexibility may be related to PTM, the significantly lower amount of covalently bound phosphate on the hibernator form. Endogenous kinase and phosphatase stimulation could reveal a stability function for PTM of LDH. Urea $\mathrm{I}_{50}$ in kinase-treated hibernator liver samples (Fig 4.23) showed elevated values, similar to euthermic controls. Upon phosphatase stimulation, euthermic urea $\mathrm{I}_{50}$ values decreased to hibernator control values with no change in hibernator stability compared to controls. This data suggests that phosphorylation does convey some stability to liver LDH. Data on the muscle form showed no changes in urea $\mathrm{I}_{50}$ upon kinase or phosphatase stimulation suggesting that stability in muscle is not dependant on PTM (Fig 4.24). 


\section{Conclusion}

Regulatory PTM of LDH has not been previously reported. This enzyme is shown to be disassociated during torpor and subunits are found in other compartments (Van Hall, 2000). There is also an apparent need for this enzyme to be functional during torpor as glycolytic flux is reduced (Storey, 1987). The classical definition of reversible phosphorylation regulation is an enzyme that is in a high (or fully) phosphorylated condition in one metabolic/physiological state and a low phosphate (or fully dephosphorylated) condition in another, such as euthermia vs torpor, and that this differential phosphorylation state changes some kinetic parameters. LDH seems to fit this definition as it is differentially phosphorylated and there are some kinetic differences in the liver enzyme between euthermic and hibernating states with respect to $\mathrm{NAD}^{+}$and in the muscle with respect to pyruvate and $\mathrm{NAD}^{+}$. The phosphorylation may be critical for normal euthermic functioning in muscle in the pyruvate utilizing direction. The phosphorylation also seems to enhance the stability to the liver euthermic form. 


\section{Chapter 5}

\section{General Discussion}


Reversible protein phosphorylation (RPP) is a common covalent PTM used in large numbers of enzymatic pathways in order to regulate substrate flux in an energetically inexpensive manner. This scenario is advantageous for endotherms that can uncouple their thermo-regulatory system in response to lowered ambient temperatures and food availability as seen in hibernation because enzymatic function must remain active in the torpid state. There are several examples of the use of RPP in the control of key metabolic points when hibernators descend into torpor including phosphofructokinase, pyruvate kinase, and pyruvate dehydrogenase complex (Storey and Storey, 2004), glutamate dehydrogenase (Bell and Storey, 2010 in press) and creatine kinase (Dieni and Storey, 2009) in response to altered environmental stress. Normally, RPP conveys on the enzyme altered kinetic and sometimes stability changes which meet the needs of the organism under this changed state. In early studies, enzymes that were considered to be control points in pathways because of their large negative free energy and unidirectional character were the first to be examined for RPP in conjunction with allosteric and hormonal control. Enzymes that are considered to be equilibrium enzymes, ones that have free energy values close to 0 , could also be regulated by mechanisms other than substrate concentration in order to favor one direction over another although they have received little study to date. There are several candidate enzymes in mammalian hibernation which could possibly be regulated by a PTM such as protein phosphorylation in order to alter their action during torpor. The present thesis examined two of them. Gycerol-3-phosphate dehyrogenase (G3PDH) (E.C.1.1.1.8) and lactate dehydrogenase (LDH) (E.C. 1.1.1.27) are two reversible cytosolic $\mathrm{NAD}^{+}$dependant enzymes that are connected directly to glycolysis. G3PDH is the bridging enzyme that allows glycerol-3- 
phosphate (derived from lipid catabolism) to be used by glycolysis and LDH converts pyruvate to lactic acid in times of elevated metabolic flux through glycolysis. There have been several attempts to link these two enzymes in terms of cytosolic $\mathrm{NAD}^{+}$potential including the possibility of a direct protein-protein binding connection which has been discredited (Brooks and Storey, 1991). Other studies show the effects of pyruvate, lactic acid and glycerol on tetramer/dimer formation of LDH (Yamamoto and Storey, 1988a, b). However, looking at both of these enzymes in terms of PTM by RPP had yet to be examined and the present study was designed to provide insight into the relationship between G3PDH and LDH during torpor, especially during the early stages of MRE.

G3PDH was shown to be differentially phosphorylated with accompanying kinetic and stability changes between its euthermic and hibernator forms in both liver and muscle with the hibernator form having significantly lower $K_{m} G 3 P$ and the euthermic form having reduced urea stability. LDH showed similar, yet not as dramatic, effects with the euthermic form having greater phosphate content in both tissues and reduced $\mathrm{K}_{\mathrm{m}}$ pyruvate (muscle only). The liver hibernator form also had significantly reduced urea stability which could be accounted for by RPP. Since MRD in ground squirrels is characterized by a shift in fuel metabolism to the oxidation of fatty acids, there should be a continuous influx of glycerol imported from the breakdown of triglycerides reserves in adipose tissue, especially in the liver where G3P is shunted into gluconeogenesis.

Glycerol concentrations do have effects on LDH dimer/tetramer ratios however glycerol can be further metabolized to G3P during torpor. An investigation of glycerol kinase in the hibernators (especially whether it is also regulated by PTM) could provide more insight into the regulation of glycerol metabolism and its role as a fuel and a possible 
enzyme regulator during torpor. More importantly, does the RPP status of LDH or G3PDH influence the dimer/tetramer ratios of LDH and possibly G3PDH? G3PDH is reported to be a dimer in several systems but these are under normal physiological conditions (Niesel et al., 1980) or in yeast (Albertyn et al., 1992). The former paper also brings up the possibility of G3PDH having multiple isoforms, another way for regulating enzymatic parameters. This is more common in organisms that have extended genomes due to polyploidy such as rainbow trout (Hochachka and Somero, 1984) and could be a factor in G3PDH regulation. However, based on the $\mathrm{K}_{\mathrm{m}}$ vs temperature curves for G3PDH in liver and muscle, this is unlikely. However, Yamamoto and Storey (1988a,b) do show the influence of glycerol on LDH activity and this can be expanded to include G3PDH with RPP as an additional factor. What effects do glycerol, G3P, pyruvate and lactic acid have on the activity and multimeric formation of both phosphorylated/dephosphorylated LDH and G3PDH at various temperatures? Another factor that can be examined is the role of $\mathrm{NADP}^{+}$in G3PDH metabolism as this enzyme can use this substrate in place of $\mathrm{NAD}^{+}$. Euthermic vs hibernator G3PDH can be examined with this substrate in conjunction with $\mathrm{NAD}^{+} / \mathrm{NADP}^{+}$ratio differences between normal and hibernating tissues.

Overall, then, the present study of dehydrogenases in liver and muscle of hibernating ground squirrels adds a new dimension to the control of mammalian G3PDH and LDH by documenting the involvement of RPP in making state-specific changes to the kinetic properties and protein stability of the enzymes. This study adds both to our understanding of the control of metabolism in hibernating mammals and indicates that 
there is still much to be learned about the basic control mechanisms operating on mammalian cytosolic dehydrogenases 


\section{References}


Abnous, K., Storey, K. B. 2007. Regulation of skeletal muscle creatine kinase from a hibernating animal. Archives of Biochemistry and Biophysics, 467, 10-19.

Albertyn, J., van Tonder, A., Prior, B. A. 1992. Purification and characterization of glycerol-3-phosphate dehydrogenase of Saccharomyces cerevisae. Federation of European Biochemical Societies, 308, 2, 130-132.

Berg, J., Tymoczko, J. L., Stryer, L. 2002. Biochemistry $5^{\text {th }}$ Edition. W. H. Freeman and Company, 41 Madison Avenue, New York, New York, 10010.

Berrada, W., Naya, A., Iddar, A., Bourhim, N. 2002. Purifiaction and characterization of cytosolic glycerol-3-phosphate dehydrogenase from skeletal muscle of jerboa (Jaculus orientalis). Molecular and Cellular Biochemistry, 231, 117-127.

Brooks, S.P.J. 1994. A program for analyzing enzyme rate data obtained from a microplate reader. BioTechniques, 17, 1154-1161.

Brooks, S. P. J., Storey, K. B. 1991. Re-evaluation of the glycerol-3-phosphate dehydrogenase/L-lactate dehydrogenase enzyme system: Evidence against the direct transfer of NADH between active sites. Journal of Biochemistry, 278, 875-881.

Carey, H. V., Andrews, M. T., Martin, S. L. 2003. Mammalian hibernation: cellular and molecular responses to depressed metabolism at low temperature. Physiol Rev, 83, 11531181 .

Chiou, S., Lee, H., Chang, G. 1990. Kinetic analysis of duck €-crystallin, a lens structural protein with lactate dehydrogenase activity. Journal of Biochemistry, 267, 51-58.

Daan, S., Barnes, B. M., Strijkstra, A. M. 1991. Warming up for sleep? Ground squirrels sleep during arousal from hibernation. Neuroscience Letters, 128, 265-268.

De Bari, L., Atlante, A., Valenti, D., Passarella, S. 2004. Partial reconstruction of in vitro gluconeogenesis arising from mitochondrial L-lactate uptake/metabolism and oxaloacetate export via novel L-lactate translocators. Biochemistry Journal, 380, 231242. 
Galster, W. A., Morrison, P. R. 1970. Cyclic changes in carbohydrate concentrations during hibernation in the actic ground squirrel. American Journal of Physiology, 218, 1228-1232.

Geiser, F. 2004. Metabolic rate and body temperature reduction during hibernation and daily torpor. Annual Review of Physiology, 66, 239-274.

Goldberg, E. 1965. Lactate dehydrogenases in trout: Evidence for a third subunit. Science, 148, 391

Hochachka, P. W., Somero, G. N. 1984. Biochemical Adaptation. Princeton University Press, 41 William Street, Princeton, New Jersey.

Hoffmann, K. H., Radeke, U. 1978. Stability of invertebrate muscle pyruvate kinases: correlation with enzyme regulatory properties. Comparative Biochemistry Physiology, 61B, 321-325.

Johnston, I. A. Cellular responses to an altered body temperature: The role of alterations in the expression of protein isoforms. Cellular Acclimatization to Environmental Change. Cossins and Sheterline, 17, 121-143.

Larsson, K.,Ansell, R., Eriksson, P., Adler, L. 1993. A gene encoding sn-glycerol 3phosphate dehydrogenase (NAD+) complements an osmosensitive mutant of Saccharomyces cerevisiae. Molecular Microbiology, 10, 5, 1101-1111.

McArthur, M. D., Milsom, W. K. 1991. Changes in ventilation and respiratory sensitivity associated with hibernation in Columbian (Spermophilus columbianus) and goldenmantled (Spermophilus lateralis) ground squirrels. Physiological Zoology, 64, 940-959.

Mehrani, H., Storey, K. B. 1997. Protein kinase C from bat brain: the enzyme from a hibernating mammal. Neurochem International, 31, 139-150.

Moon, T. W. 1978. Enzymes of heterotherms; LDH of hibernating and normothermic little brown bats, Myotis lucifugus. Comparative Biochemistry and Physiology, 59B, 183-190. 
Niesel, D. W., Bewley, G. C., Miller, S. G., Armstrong, F. B. 1980. Purification and structural analysis of the soluble sn-glycerol-3-phosphate dehydrogenase isozymes in Drosophilia melanogaster. The Journal of Biochemical Chemistry, 255, 9, 4073-4080.

Ohira, R. H., Dipple, K. M., Zhang, Y., McCabe, E. R. B. 2005. Human and murine glycerol kinase: Influence of exon 18 alternative splicing on function. Biochemical and Biophysical Research Communications, 331, 239-246.

Panchal, A. R., Comte, B., Huang, H., Dudar, B., Roth, B., Chandler, M., Des Rosiers, C., Brunengraber, H., Stanley, W. C. 2001. Acute hibernation decreases myocardial pyruvate carboxylation and citrate release. American Journal of Physiology, Heart Circulation Physiology, 281, H1613- H1620.

Passmore, J. C., Pfeiffer, E. W., Templeton, J. R. 2005. Urea excreation in the hibernating Columbian ground squirrel (Spermophilus columbianus). Journal of Experimental Zoology, 192, 1, 83-86.

Somero, G. N. 1995. Proteins and temperature. Annual Review of Physiology, 57, 43-68.

Somero, G. N., Hochachka, P. W. 1976. Biochemical adaptations to temperature. American Zoologist, 11, 159-167.

Stewart, J. M., Woods, A. K., Blakely, J. A. 2005. Maximal enzyme activities, and myoglobin and glutathione concentrationsin heart, liver and skeletal muscle of the Northern Short-tailed shrew (Blarina brevicauda; Insectivora: Soricidae). Comparative Biochemistry and Physiology, Part B, 141, 267-273.

Storey, K. B. 1987. Investigations of the mechanisms of glycolytic control during hibernation. Canadian Journal of Zoology, 65, 3079-3083.

Storey, K. B. 1997. Metabolic regulation in mammalian hibernation: enzyme and protein adaptations. Comparative Biochemistry and Physiology, 118A, 4, 1115-1124. 
Storey, K. B., Storey, J. M. 2004. Mammalian hibernation: Biochemical adaptation and gene expression. Functional Metabolism: Regulation and Adaptation, edited by Kenneth B. Storey. John Wiley and Sons, Inc.

Storey, K. B., Storey, J. M. 2007. Tribute to P. L. Lutz: putting life on 'pause' molecular regulation of hypometabolism. Journal of Experimental Biology, 210, 17001714.

Tashima, L. S., Adelstein, S. J., Lyman, C. P. 1970. Radioglucose utilization by active, hibernating and arousing ground squirrels. American Journal of Physiology, 218, 303309.

Van Hall, G. 2000. Lactate as a fuel for mitochondrial respiration. Acta Physiol Scand, $168,643-656$

Voet, D., Voet, J. G. 2004. Biochemistry $3^{\text {rd }}$ Edition. John Wiley and Sons Inc.

Yamamoto, S., Storey, K. B. 1988a. Dissociation-assciation of lactate dehydrogenase isozymes: influences on the formation of tetramers versus dimmers of M4-LDH and H4LDH. International Journal of Biochemistry, 20, 11, 1261-1265.

Yamamoto, S., Storey, K. B. 1988b. Influence of glycerol on the activity and tetramerdimer state of lactate dehydrogenase isozymes. International Journal of Biochemistry, 20, $11,1267-1271$.

Zatzman, M. L. 1984. Renal and cardiovascular effects of hibernation and hypothermia. Cryobiology, 21, 593-614. 